\title{
EFFECTS OF THE CABINET GORGE KOKANEE HATCHERY \\ ON WINTERING BALD EAGLES IN THE LOWER CLARK \\ FORK RIVER AND LAKE PEND OREILLE, IDAHO
}

Final Report 1986

\section{Prepared By}

John G. Crenshaw, Project Leader Wildlife Research Section

Idaho Department of Fish and Game 600 South Walnut

P.O. Box 25

Boise, Idaho 83707

\section{Prepared For}

\author{
James R. Meyer, Project Manager \\ U.S. Department of Energy \\ Bonneville Power Administration \\ Division of Fish and Wildlife \\ P.O. Box 3621 \\ Portland, Oregon 97208 \\ Project No. 86-14 \\ Contract No. DE-Al79-86BP60790
}




\section{$\underline{\text { PAGE }}$}

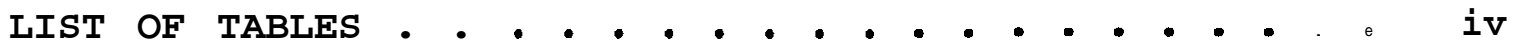

IIST OF FIGURES . . . . . . . . . . . . . . . . . . . vi vi

LIST OF APPENDICES . . . . . . . . . . . . . . . . ix

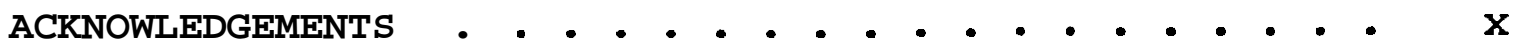

ABSTRACT . . . . . . . . . . . . . . . . . . . . xi

INTRODUCTION

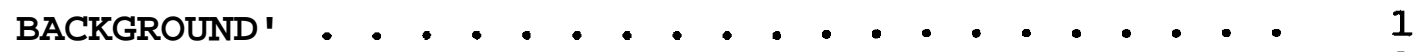

GOAL . . . . . • • . . . . . • • • • • • • . . 2

OBJECTIVES . . • • . . . . . . . . . . . . . 2

STUDY AREA . . . . . . . . . . . . . . . . . . . 3

METHODS AND MATERIALS . . . . . . . . . . . . . . . . 6

BALD EAGLE ABUNDANCE AND DISTRIBUTION . . . . . . . 6

CAPTURE AND MOVEMENTS OF BALD EAGLES . . . . . . . 8

NOCTURNAL ROOSTS . . . . . . . . . . . . . . . 10

HABITAT DESCRIPTION . . . . . . . . . . . . . . 11

BEHAVIORAL ACTIVITY BUDGETS . . . . . . . . . • • . 11

FEEDING HABITS . . . . . . . . . . . . . . . . . . . . . 14

SALMON CARCASS AVAILABILITY FROM CABINET GORGE

HATCHERY . . . . . . . . . . . . . . . . . . 14

RESULTS AND DISCUSSION . . . . . . . . . . . . . . . . . 16

BALD EAGLE ABUNDANCE AND DISTRIBUTION . . . . . . . 16

Total Study Area . . . . . . . . . . . . . . . 16

Lake Pend Oreille . . . . . . . . . . . . . . . 23

Clark Fork River . . . . . . . . . . . . . . . 29

Pend Oreille River . . . . . . . . . . . . . . 29

CAPTURE AND MOVEMENTS OF BALD EAGLES . . . . . . . 34

Eagle\#01...................... 34

Eagle\#02 . . . . . . . . . . . . . . . . . . . 34

.Eagle\#03 . . . . . . . . . . . . . . . . . . . . 41

Eagle\#04 . . . . . . . . . . . . . . . . . . . 44

Eagle\#05 . . . . . . . . . . . . . . . . . . . 44 44

Eagle\#06 . . . . . . . . . . . . . . . . . . . 46

Eagle\#07 . . . . . . . . . . . . . . . . . . . 46

Eagle\#08 . . . . . . . . . . . . . . . . . . . . . 46

Interchange of Eagles With McDonald Creek

Concentration . . . . . . . . . . . . . . . . 51

NOCTURNAL ROOSTS . . 51

Warren Island Roost .. 53

East Bottle Bay Roost..................... 53

Echo Bay Roost . . . . . . . . . . . . . . . . 58

BALD EAGLE NESTS . . . . . . . . . . . . . . . . 58 


\section{$\underline{\text { PAGE }}$}

HABITAT DESCRIPTION . . . . . . . . . . . . 61

Lake Pend Oreille... . . . . . . . . . . . . 61

Clark Fork River . . . . . . . . . . . 61

Pend Oreille River' . . . . . . . . . . 61

BEHAVIORAL ACTIVITY BUDGET; . . . . . . . . . . . 65

FEEDING HABITS . . . . . . . . . . . . . . . . . . 70

Behavioral Activity Budgets . . . . . . . . . . 70

Analysis of Cast Pellets And Remains Eagle

Prey Items . . . . . . . . . . . . 70

SALMON CARCASS AVAILABILITY FROM CABINET GORGE

SUMMARY . . . . . . . . . . . . . . . . . . . 77

LITERATURE CITED . . . . . . . . . . . . . . . . 79

APPENDICES . . . . . . . . . . . . . . . . . . 82 


\section{LIST OF TABLES}

TABLE

PAGE

1 Peak counts of bald eagles in aerial censuses of the study area, 1985-86 and 1986-87 . . . . 18

2 Peak counts of bald eagles in aerial censuses of Lake Pend Oreille, the lower Clark Fork River, and the upper Pend Oreille River, 1985-86 and 1986-87 . . . . . . . . . . . . . .

3 Description of bald eagle use areas by lake-mile (LM) on Lake Pend Oreille, 1985-86 and 1986-87 . . . . . . . . . . . . . . . . .

4 Age classes, capture dates, and residencies of transmitter-equipped bald eagles, 1985-86 and 1986-87. . . . . . . . . . . . . . .

5 Counts of bald eagles at Warren Island Roost, 1985-86. . . . . . . . . . . . . . .

6 Counts of bald eagles at Warren Island Roost, 1986-87 . . . . . . . . . . . . . . . .

7 Characteristics of eight roost trees at Warren Island Roost, 1987 . . . . . . . . . . . . . 56

8 Counts of bald eagles at East Bottle Bay Roost, 1985-86 and 1986-87 . . . . . . . . . . . . .

Characteristics of four roost trees at East Bottle Bay Roost, 1987

Bald eagle incubation dates, nest productivity, and land ownership on Lake Pend Oreille, the lower Clark Fork River, and the upper Pend Oreille River, 1986 and 1987 . . . . . . . . . 60

11 Habitat description of Lake Pend Oreille shoreline zones $(100 \mathrm{~m}$ width $)$. . . . . . . . . . 62

12 Habitat description of Lake Pend Oreille upland zones ( $1.6 \mathrm{~km}$ width)

13 Dates and sites of behavioral activity budget sessions of bald eagles, 1985-86 and 1986-87.

Preference of a) species and b) structure classifications of perch trees by bald eagles in aerial censuses, 1985-86 and 1986-87.. 
15 Observations of foraging events by bald eagles during time budget sessions, 1985-86 and $1986-87$

16

Frequency of occurrence of prey species in 368 cast pellets of bald eagles at Lake Pend Oreille, 1985-86 $(N=200)$ and 1986-87 $(N=168)$. . .

17 Releases and surveys of tagged kokanee salmon carcasses on the lower Clark Fork River, 1986 . 


\section{LIST OF FIGURES}

FIGURE

PAGE

1 Map of study area . . . . . . . . . . . . . . 4

2 Map of area covered in aerial censuses of bald eagles, 1985-86 and 1986-87 . . . . . . . 7

3 Floating kokanee salmon capture system for bald eagles . . . . . . . . . . . . . . . . . . 9

4 Map of habitat use zones on Lake Pend Oreille 12

5 Locations of observation sites for bald eagle behavioral activity budgets, 1985-86 and 1986-87 . . . . . . . . . . . . . . . 13

6 Numbers of bald eagles in aerial censuses of the study area, 1985-86 and 1986-87 . . . . . 17

7 Numbers of adult and subadult bald eagles in aerial censuses of the study area, 1985-86. .

8 Numbers of adult and subadult bald eagles in aerial censuses of the study area, 1986-87 . . 20

9 Percent subadult bald eagles in aerial censuses of the study area, 1985-86 and 1986-87.

10 Mid-winter bald eagle censuses of the study area, excluding upstream of Cabinet Gorge Dam, 1981-84 and 1986-87 . . . . . . . . . . . . . 22

11 Numbers of bald eagles in aerial censuses of Lake Pend Oreille, 1985-86 and 1986-87 . . . . 25

12 Distribution of bald eagle use areas on Lake Pend Oreille, 1985-86 and 1986-87 . . . . . . 27

13 Mean number of bald eagles per mile shoreline on northern Lake Pend Oreille, 1985-86 and 1986-87

14 Mean number of bald eagles per mile shoreline on southern Lake Pend Oreille, 1985-86 and 1986-87 . . . . . . . . . . . . . . . . . . 30

15 Numbers of bald eagles in aerial censuses of the lower Clark Fork River, 1985-86 and 1986-87

vi 
16 Distribution of total numbers of bald eagles in aerial censuses of the lower Clark Fork River, 1985-86 and 1986-87 . . . . . . . . .

17 Numbers of bald eagles in aerial censuses of the upper Pend Oreille River, 1985-86 and 1986-87

18 Distribution of total numbers of bald eagles in aerial censuses of the upper Pend Oreille River, 1985-86 and 1986-87 . . . . . . . . .

19 Numbers of bald eagles in aerial censuses of the Pend Oreille River from Smith Creek to Albeni Falls Dam, 1985-86 and 1986-87 . . . . 36

20 Numbers of bald eagles in aerial censuses and residencies of transmitter-equipped bald eagles, 1985-86. . . . . . . . . . . . . . . 38

21 Numbers of bald eagles in aerial censuses and residencies of transmitter-equipped bald eagles, 1986-87 . . . . . . . . . . . . . . . 38

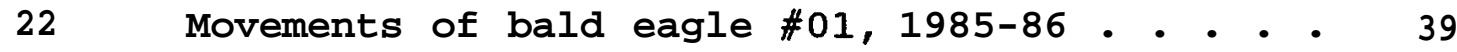

23 Movements of bald eagle \#02, 1985-86 . . . . . 40

24 Movements of bald eagle \#03, 1985-86 . . . . . 42

25 Movements of bald eagle \#03, 1986-87 . . . . . 43

26 Movements of bald eagle \#05, 1985-86 and 1986-87 . . . . . . . . . . . . . . . . . . . 45

27 Movements of bald eagle \#06, 1985-86 . . . . . 47

28 Movements of bald eagle \#06, 1986-87 . . . . . 48

29 Movements of bald eagle $\# 07,1985-86 . . .4 .49$

30 Movements of bald eagle \#08, 1985-86 and 1986-87 . . . . . . . . . . . . . . . . . . 50

31 Map of major nocturnal roosts of bald eagles on Lake Pend Oreille and bald eagle nests, 1985-86 and 1986-87 . . . . . . . . . . . . . 52

32 Map of land ownership surrounding Lake Pend Oreille, 1987 . . . . . . . . . . . . . . . 
33 Time budget categories of bald eagles on Lake Pend Oreille, 1985-86 and 1986-87. . . . . . .

34 Time budget categories for locomotion of bald eagles on Lake Pend Oreille, 1985-86 and 1986-87. . . . . . . . . . . . . . . . . .

35 Perch substrates used by bald eagles on Lake Pend Oreille, 1985-86 and 1986-87 . . . . . . 68

36 Hunting success by bald eagles on Lake Pend Oreille, 1985-86 and 1986-87 . . . . . . . . .

37 Feeding substrates of bald eagles on Lake Pend Oreille, from time budget sessions, 1985-86 and 1986-87 . . . . . . . . . . . . . . . .

38 Preening substrates of bald eagles on Lake Pend Oreille, 1985-86. . . . . . . . . . . 


\section{LIST OF APPENDICES}

APPENDIX

$\underline{\text { PAGE }}$

A Field data forms and eagle behavior codes . . A-I

B Locations of bald eagles in weekly aerial censuses of Lake Pend Oreille, 1985-86 and 1986-87 . . B-I

C Biological data on captured bald eagles on Lake Pend Oreille, 1986 . . . . . . . . . . . C-I

D Maps of bald eagle communal roosts on Lake Pend Oreille, 1985-86 and 1986-87 . . . . . . D-I 


\section{ACKNOWLEDGEMENTS}

I gratefully acknowledge the support of Jim Meyer

(Bonneville Power Administration), Pete Zager (Idaho Department of Fish and Game [IDFG], and Rich Howard (U.S. Fish and Wildlife Service) for initiation of this study through the preparation and submission of the project proposal upon which it was based. The enthusiasm and hard work of field assistants Kathleen Fulmer and Chuck Kilpatrick, and volunteer Chris Bertellotti were invaluable to the collection of data during often less than ideal conditions. Without the technical and logistical support of Lonn Kuck, John Beecham (IDFG), and others, and funding for graphics production from the U.S. Fish and Wildlife Service, this study would never have reached a successful conclusion.

Thanks goes to Lenny Young (Bureau of Land Management) for instruction on preparation of bald eagle capture equipment and techniques, and advice on study design; to Dave Anderson (Pacific Power and Light Company) for advice on eagle backpack transmitter attachment; to Steve Heibert and Dave Thorson (U.S. Forest Service [USFS]) for aerial photo interpretation upon which the habitat description of lands surrounding Lake Pend Oreille was based: to Craig Rindlisbacher (University of Idaho) who spent innumerable hours digitizing eagle census data and producing distribution maps;' to Bill Brooks (Brooks Seaplane Service) for his flight experience and good humor resulting in the completion of nearly all scheduled aerial censuses; to Kevin Carson (University of Idaho Media Center) for the production of high quality graphics; and to Chuck Mancuso (University of Idaho Research and Extension Center, Sandpoint) and Jack Dawson (North Idaho College) for use of computer facilities. Finally, I extend my appreciation and gratitude to my wife, Laurie, who assisted in fieldwork and helped me overcome the hurdles and savor the successes. 
Effects of the Cabinet Gorge Kokanee Hatchery on wintering bald eagles in the lower Clark Fork River and Lake Pend Oreille, Idaho

The abundance and distribution of bald eagles (Haliaeetus leucocephalus) on the lower Clark Fork River, Lake Pend Oreille, and the upper Pend Oreille River, Idaho, were documented during the winters of $1985-86$ and 1986-87. Peak counts of bald eagles in weekly aerial censuses were higher in 1985-86 (274) and 1986-87 (429) than previously recorded in mid-winter surveys. Differences in eagle distribution within and between years were apparently responses to changes in prey availability.

Eight bald eagles were captured and equipped with radio transmitters in the winter and spring of 1986. Residencies within the study area averaged 13.9 days in $1985-86$ and 58.3 days for the four eagles that returned in 1986-87. The eagles exhibited considerable daily movement throughout the study area. After departing the area, one eagle was later sighted approximately $1,185 \mathrm{~km}$ to the southwest in northern California.

Three major communal roosts used by bald eagles were identified. Two roosts were located on federally-owned land: one was on a privately-owned island. Eagles roosted in Douglas-fir (Pseudotsusa menzeisii), western larch (Larix occidentalis), and black cottonwood (Populus trichocaroa) that averaged $63.1 \mathrm{~cm}$ diameter at breast height and $33.5 \mathrm{~m}$ height. Each site was relatively secure from human disturbance during its period of use.

The most common habitat types along the shoreline and upland areas adjacent to Lake Pend Oreille were western redcedar (Thuia plicata)/queencup beadlily (Clintonia uniflora) and Douglas-fir/ninebark (Physocarpus malvaceus). Greater than 50\% of the area was forested: in the upper canopy, mean tree height exceeded $22 \mathrm{~m}$ and mean density exceeded 3 trees/ha. Land ownership adjacent to the lake was predominately private in the north and federal in the south.

Eagle behavioral activity was recorded at time budget sessions at areas of heavy use. Perching in live trees was the most common behavior observed; ponderosa pine (Pinus ponderosa), Douglas-fir, and black cottonwood were preferred 
tree species. Overall capture success rate of fish was greater than 85\%: aerial capture was most successful (78\%).

Remains of birds found in regurgitated pellets of bald eagles $(N=208)$ were followed in numbers by remains of fish $(\mathrm{N}=175)$ and mammals $(\mathrm{N}=21)$. Prey remains collected under diurnal feeding perches consisted mostly of fish, primarily Lake Superior whitefish (Coresonas clupeaformis) and (kokanee salmon [Onchorhynchus nerka).

Recoveries of tagged salmon carcasses placed in the Clark Fork River below Cabinet Gorge Dam indicated midchannel releases were most effective in making carcasses accessible to foraging eagles. 


\section{INTRODUCTION}

\section{BACKGROUND}

The bald eagle (Haliaeetus leucocephalus) has received "Endangered" species status by the U.S. Department of Interior in 43 of the lower 48 contiguous states and is listed as "Threatened" in the other five states (U.S. Fish and Wildlife Service 1984). The designation of the species as "Endangered" in Idaho has required state and federal agencies to protect important bald eagle habitat.

Lake Pend Oreille, in northern Idaho, has hosted a population of wintering bald eagles which is drawn to the area by an abundance of fish residing in the lake, by waterfowl migrating south from Canada, and by the presence of open water conditions during winter. The availability of kokanee salmon (Onchorhvnchus nerka) which spawn in the lake and its tributaries from November to January has been linked to the presence of wintering bald eagles in the area (Myer 1979). Kokanee salmon were inadvertently introduced into the Clark Fork River system from Flathead Lake as a result of a flood event in the mid-1930's. By the 1940's and 1950's Lake Pend Oreille had developed into a major sport and commercial fishery with more than one million salmon harvested annually from 1950-65.

Even though the fishery was highly productive during this period, several factors began to influence its stability. The dewatering of salmon redds by lower lake levels as a result of water releases at Albeni Falls Dam downstream on the Pend Oreille River contributed to a decline in annual recruitment in the population. In addition, major spawning runs of salmon that migrated upstream in the Clark Fork River were blocked by the construction of Cabinet Gorge Dam, thus eliminating approximately $90 \%$ of the spawning area in the system. The complexity and severity of the salmon's population status increased still further with the establishment of non-native oppossum shrimp (Mysis relicta) which compete with young kokanee salmon for zooplankton (Larry LaBolle, personal communication, 1987).

In the 1960's, the first measure was taken to ameliorate these effects when the operation of the Albeni Falls Dam was modified by establishing low pool on the lake prior to salmon spawning to minimize associated losses. In 1973, the commercial salmon fishery on the lake was eliminated. In 1976, hatchery releases of salmon by the IDFG were begun and the population began to stabilize (6-8 million salmon), but total rehabilitation of the fishery was 
prevented due to limited hatchery capacity. In 1986, construction of the Cabinet Gorge Hatchery on the lower Clark Fork River was completed and operation was begun with the task of rebuilding the salmon fishery in the lake which had by then decreased in size to approximately five million fish.

The expected enhancement of the salmon fishery in Lake Pend Oreille will have the potential to add to the significance of the area to wintering bald eagles by providing an abundant, accessible, and dependable food source at a time of increased stress. However, only limited information on the use of the area by wintering bald eagles has existed from which an evaluation could be based. The U.S. Fish and Wildlife Service in their Biological Opinion on the Cabinet Gorge Hatchery project recommended that this study be undertaken to fill the gap in baseline data on bald eagle use.

GOAL

The goal of this study was to obtain baseline data on bald eagles wintering along the lower Clark Fork River and Lake Pend Oreille, Idaho. It was designed to identify important bald eagle habitat that will allow a future assessment to be made of the effects to bald eagles resulting from the enhancement of the kokanee salmon fishery, and to provide information from which management decisions can be based for the protection and enhancement of eagle habitat.

\section{OBJECTIVES}

The objectives of the study were to:

1. Determine the seasonal changes in the numbers and distribution of wintering bald eagles.

2. Identify and characterize important bald eagle perching, feeding, and roosting areas.

3. Determine the species of prey used by bald eagles.

4. Determine the daily flight patterns and behavioral . activities of wintering bald eagles.

5. Develop recommendations for the protection and/or enhancement of bald eagle habitat along the lower Clark Fork River and Lake Pend Oreille. 
The primary study area is located in the Panhandle region of Idaho and encompasses the lower $50 \mathrm{~km}$ of the Clark Fork River, $184 \mathrm{~km}$ of shoreline on Lake Pend Oreille, and the upper $12 \mathrm{~km}$ of the Pend Oreille River which flows eventually into the Columbia River (Fig. 1). It is situated in a migration corridor between bald eagle summering areas to the north in Canada and wintering areas further to the south in Idaho, Montana, Nevada, Oregon, Utah, and Wyoming. The climate of the area is influenced by Pacific weather systems and is often wet and cold in winter. The mean minimum temperature has averaged -4.1 degrees Celsius and the mean precipitation $10.1 \mathrm{~cm}$ at Sandpoint for the period of November through May from 1951-80.

Lake Pend Oreille is a deep (mean depth $=164 \mathrm{~m}$; maximum depth $=351 \mathrm{~m}$ ), temperate, oligotrophic lake (Bowles et al. 1986). It is the largest lake in Idaho with approximately $184 \mathrm{~km}$ of shoreline and lies at $625 \mathrm{~m}$ elevation. It is bordered by the Cabinet Mountains to the northeast, the Green Monarch and Coeur d'Alene mountains to the southeast, and the Selkirk Mountains to the northwest. The northern half of the lake is characterized by several islands and numerous bays, some with extensive shallows; the shoreline along the southern half has more rugged terrain that falls sharply into the deeper waters of the lake. Ownership of land adjacent to the lake is primarily private in the north and federal (USFS) in the south. The lake is a popular summer resort area, but human activity there becomes extremely limited in mid-winter. Many northern bays become frozen during colder winters. The level of the lake was lowered by an average of $3.6 \mathrm{~m}$ to a mean low pool of $622 \mathrm{~m}$ from November to April in 1985-86 and 1986-87 by water released at Albeni Falls Dam.

The Clark Fork River is the major source of water to the area, entering from the east in Montana out of Noxon Rapids Dam and into Cabinet Gorge Reservoir, then through Cabinet Gorge Dam into Lake Pend Oreille. It is bordered by the Cabinet Mountains to the northeast and the Bitterroot Range to the southwest. Slow-moving sections of the river above Cabinet Gorge Dam often become frozen during the winter months. Below the dam where discharge rates during the winter may fluctuate greatly (90-900 cms), the river rarely freezes. A substantial delta that exists throughout the winter at the river's mouth is often partially icebound.

The Pend Oreille River from its outlet at the northwest portion of Lake Pend Oreille as it proceeds downstream past Sandpoint remains wide and slow-moving. A higher level of 


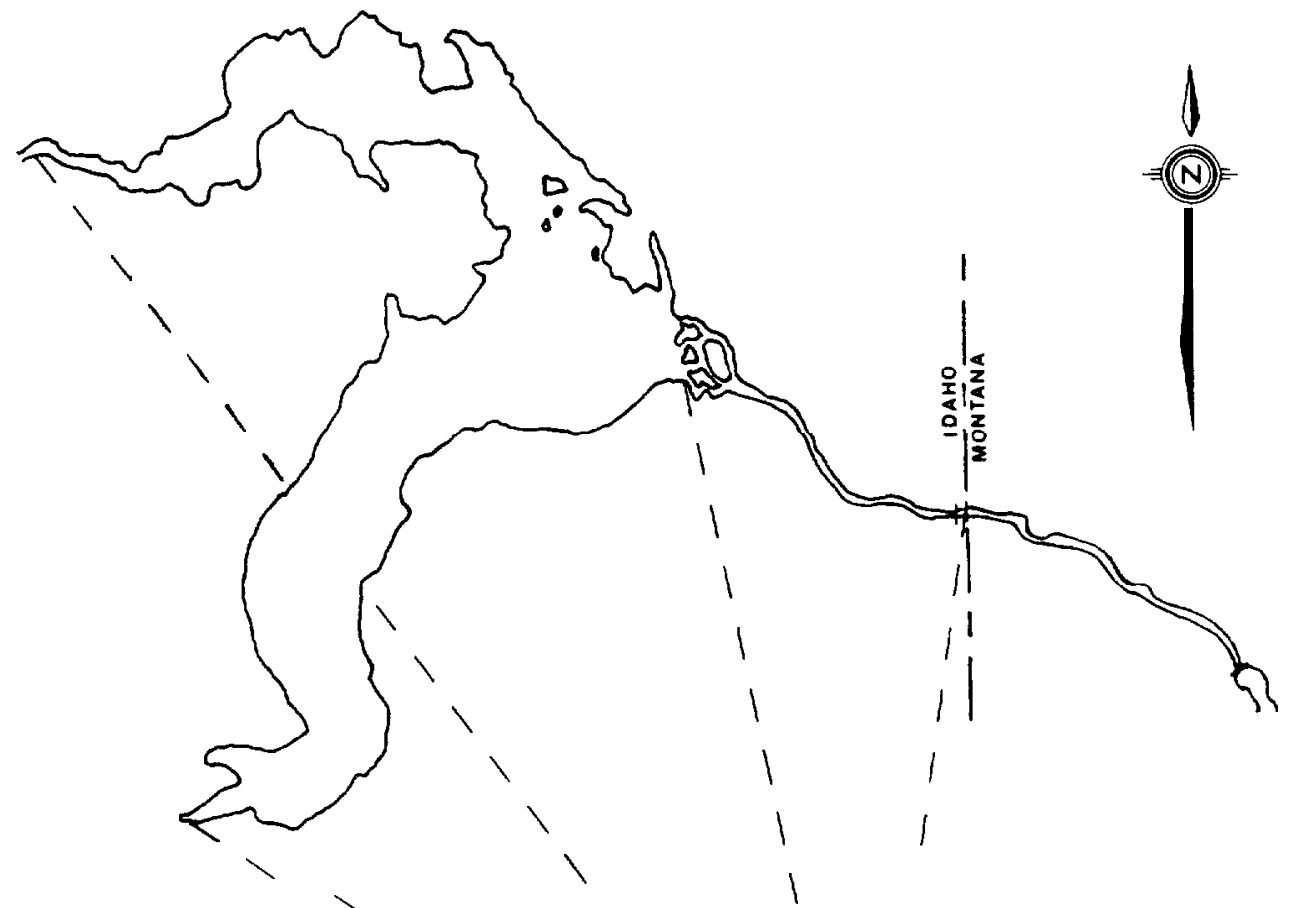

LAKE PENQ OREILEE । ।

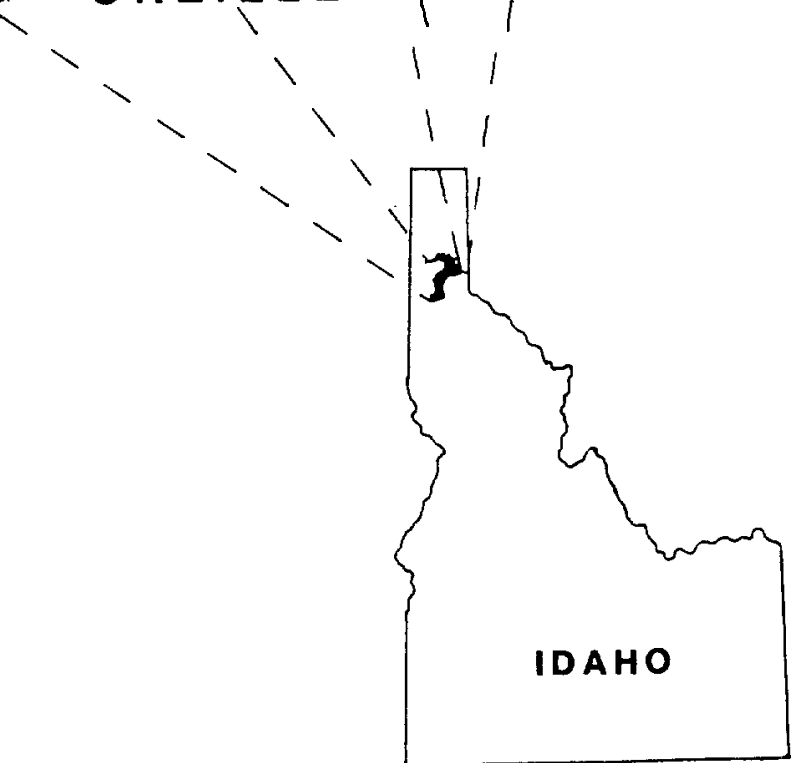

Figure 1. Map of study area. 
human activity than on the lake is present throughout the year due to its proximity to Sandpoint. Portions of this upper section of the river may freeze over for short periods during the winter months.

The Lake Pend Oreille fishery supports populations of non-native kokanee salmon, rainbow trout (Salmo sairdneri), cutthroat trout (Salmo clarki), Dolly varden (Salvelinus confluentis), brook trout (Salvelinus fontinalis), mackinaw (Salvelinus namavcush), Lake Superior whitefish (Coreoonas cluoeaformis), mountain whitefish (Prosopium williamsoni), largemouth bass (Micropterus salmoides), northern squawfish (Ptvchocheilus oresonensis), largescale sucker (Catostomas macrocheilus), and others (Bowles et al. 1987). The area is also frequented by large numbers of migrating waterfowl until the formation of ice in the shallow portions of the lake begins to limit their food accessibility. 


\section{BALD EAGLE ABUNDANCE AND DISTRIBUTION}

Weekly aerial censuses were conducted from late October (1986) and early November (1985) to early April to determine total numbers, age class composition, and seasonal distribution of bald eagles within the study area. The census route was from the delta of the Clark Fork River, Idaho, upstream to Noxon Rapids Dam, Montana, (50 km) and return (the higher of the counts used in the final tally), the shoreline of Lake Pend Oreille and its islands (184 km), and the Pend oreille River from Sandpoint downstream to Smith Creek (12 km) (Fig. 2). During the spring of 1985-86 and the field season of 1986-87, one flight per month was extended further downstream to Albeni Falls Dam (45 km).

Censuses were flown in fixed-wing aircraft (Cessna 185) at $105-140 \mathrm{~km} / \mathrm{hr}$ and 75-125 m above the water. The pilot was usually accompanied by two observers: one seated in the front (spotter), and one seated in the rear of the aircraft (recorder). The spotter called out and recorded on a tape recorder the age classes (adult: fully white head and tail; subadult: all other combinations of body plumage), numbers, locations, perch tree species and/or activities of bald eagles which were passed along the census route. The recorder assisted in spotting eagles, and followed the progress of the flight on $7.5 \mathrm{~min} U . S$. Geologic Survey (USGS) topographic maps (1:24,000 scale), while recording onto them data called out by the spotter. In isolated instances where large numbers of eagles were concentrated and the possibility of not observing some eagles increased, the aircraft was circled back sharply for an immediate recount of the area in question. The beginning and ending times of each flight, weather data (temperature, precipitation, wind velocity and direction), activity at eagle nest sites, and other pertinent information were recorded onto aerial census forms (Appendix $A-1$ ).

Censuses began between $2.6 \mathrm{hrs}$ and $6.2 \mathrm{hrs}$ after sunrise $(\bar{x}=4.2 \mathrm{hrs})$. Unfavorable flight conditions (high winds, turbulence, poor visibility) during many mornings prevented a standardized departure time and sometimes resulted in a one- or two-day postponement 'or cancellation of the flight until the following week. Census duration for the normal weekly route averaged $2.8 \mathrm{hrs}$.

A geographic information system (COMARC 1986) was used to document eagle distribution. Base maps were created by digitizing the shoreline of the lake from USGS 7.5 and $15 \mathrm{~min}$ topographic maps. Eagle locations previously 


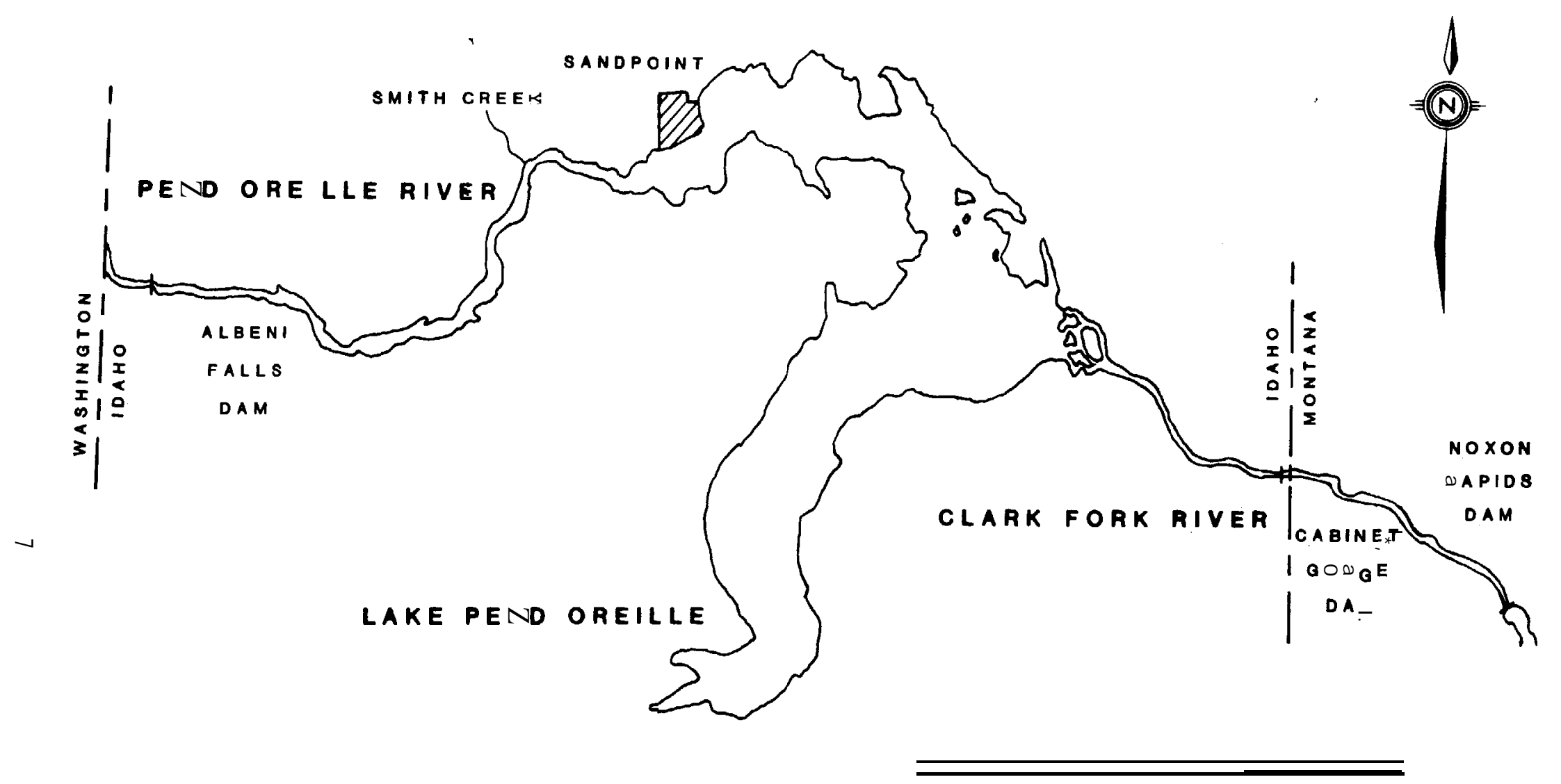

Figure 2. Map of area covered in aerial censuses of bald eagles, 1985-86 and 1986-87. 
recorded onto aerial census maps were digitized to create additional overlays which were then expanded with corresponding data on eagle age classes, activities, and perch tree species. A single map of each weekly census of Lake Pend Oreille was generated to provide an illustration of eagle abundance and distribution as the concentration progressed through the winters of 1985-86 and 1986-87. The system was also used to total the species and structure of perch trees used by bald eagles at the time of the census.

Differences in eagle distribution were examined by dividing the lake and river shoreline into units of one mile (lake-mile [LM]; river-mile [RM]). For more detailed analysis of distribution on the lake, the time spanned by the concentration periods was divided into intervals of 54 days each (early winter: 24 October to 16 December; midwinter: 17 December to 8 February: late winter: 9 February to 3 April). A Kolmogorov-Smirnov test (SYSTAT, Inc. 1986) was used to test for significant differences (of $=0.05$ ) in the cumulative distributions of eagle numbers between years.

\section{CAPTURE AND MOVEMENTS OF BALD EAGLES}

Bald eagles were captured with a floating kokanee salmon equipped with two monofilament nooses that extended laterally from the fish just above the surface of the water, as modified after Frenzel and Anthony (1982) (Fig. 3). A monofilament line tied to the nooses extended into the water to a depth of $10-20 \mathrm{~m}$ where it was connected to $1.5 \mathrm{~m}$ of elastic cord (6 mm diameter) attached to a $2 \mathrm{~kg}$ cement anchor.

Capture attempts began about sunrise from a boat by positioning 1-4 capture fish 15-50 m offshore from popular eagle perch sites. Observers then returned to a vantage point on shore to await an eagle's arrival. When a flying eagle descended and grasped the fish, its toe(s) and/or tarsus were usually encircled by one of the nooses. As tension increased on the line with the attempted departure of the eagle, the nooses closed and the eagle was pulled gently to the water's surface.

Captured eagles were approached immediately by boat and retrieved from the. water with a large fish net $(1.0 \mathrm{~m}$ diameter). They were hooded to minimize stress while being handled, restrained by securing a triangular bandage around the wings and body and by tethering the tarsi together with nylon cord, and wrapped in a wool blanket to help maintain body temperature and allow feathers to dry. Before leaving the site, capture equipment was removed from the water. Eagles were then transported to shore to undergo a series of 

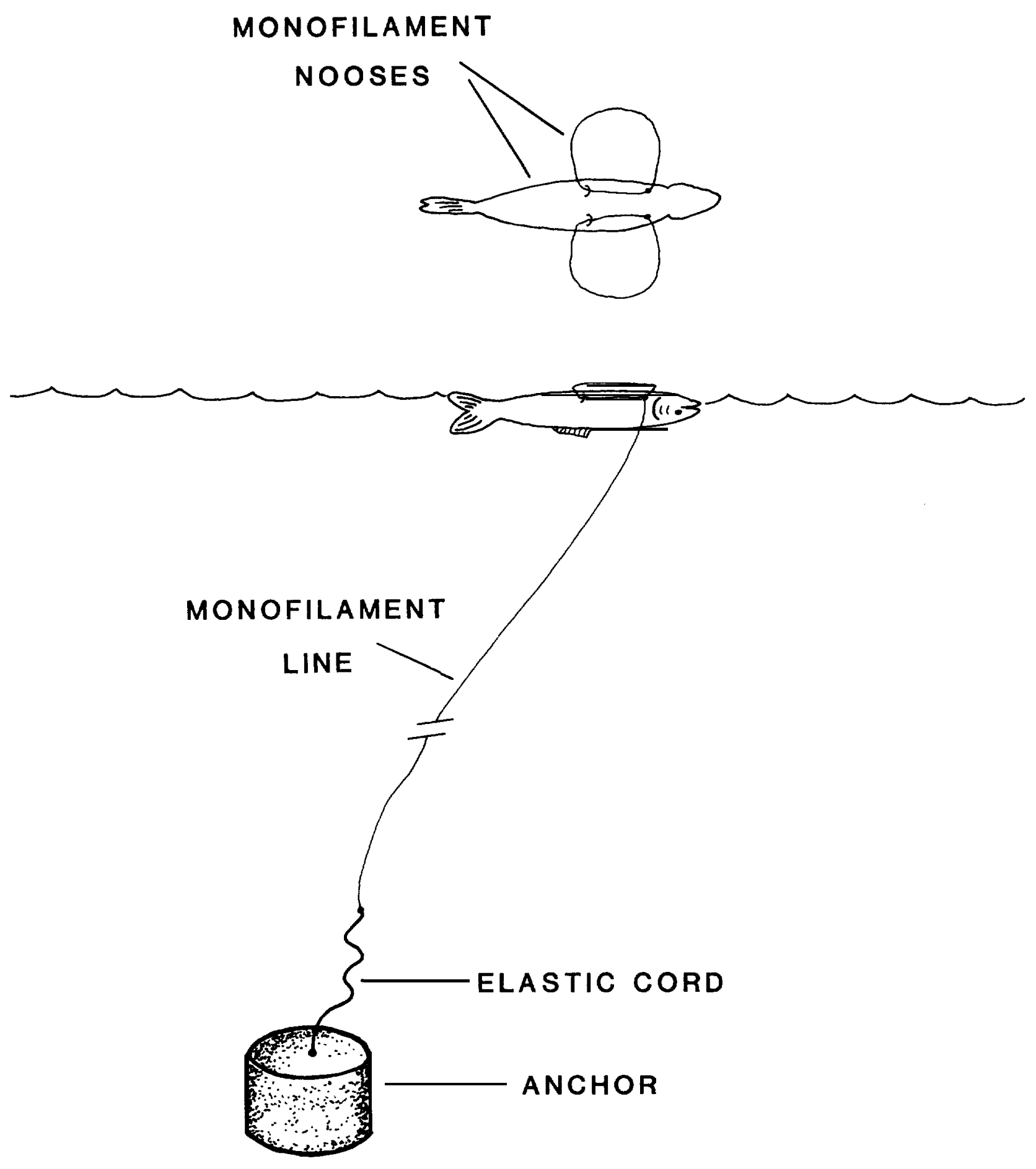

Figure 3. Floating kokanee salmoncapture syskmforbaldeagles. 
morphological measurements (Appendix A-2) for judging relative health condition and determining sex (Bortolotti 1984). U.S. Fish and Wildlife Service No. 9 aluminum bands were attached around one tarsus of each eagle.

Captured eagles were equipped with patagial wingmarkers and radio-transmitters. Wing-markers were bright green, made of vinyl-coated nylon (Cooley Inc., Anaheim, California), and numerically coded (01 to 08) dorsally with white gloss paint (Naz-Dar Co., Chicago, Illinois). Each wing-marker wrapped around the wing next to the body at a natural gap in the feathers and was held in place by an aluminum rivet through the terminal (posterior) ends of the marker. Radio-transmitter packages (Telonics, Inc., Mesa, Arizona) weighed $60 \mathrm{~g}$, had an operational life of 15 months, and were attached to each eagle in backpack configuration with $1.4 \mathrm{~cm}$ teflon ribbon (Bally Ribbon Mills, Bally, Pennsylvania). Waxed dental floss (Johnson and Johnson Products, New Brunswick, New Jersey) was used to secure the loose ends of the ribbon to each other at the base of the transmitter package after they encircled the eagle's body and to affix the point where the ribbon criss-crossed above the eagle's sternum.

Eagles were released near the capture site and observed for as long as possible to ensure no adverse effects from the capture and handling procedures. Movements of transmitter-equipped eagles were obtained by following signals during weekly census flights for final telemetry or visual confirmation and by radio-tracking and triangulation from a boat, by automobile, or on foot. Eagle locations were plotted on $7.5 \mathrm{~min}$ USGS topographic maps and characterized on data forms (Appendix $A-3$ ). Locations were evaluated based upon their type (visual or triangulation) and the degree of accuracy obtained (Heezen and Tester 1967); those locations suspected of being inaccurate were used only for providing a general area from which to begin the next radio-tracking session.

\section{NOCTURNAL ROOSTS}

Night locations of bald eagles were identified by observing eagles' flight paths and destinations after they left popular feeding sites at dusk, and by observations of eagles at previously identified roost sites. Additional roost locations and data on roost fidelity by individuals were documented by observing the roost flights of transmitter-equipped eagles or by triangulation on their night locations between one hour after sunset and one hour before sunrise. Location of roosts and roost trees frequently used by eagles were plotted on $7.5 \mathrm{~min}$ USGS 
topographic maps. Height of roost trees was measured with a clinometer; diameter at breast height (dbh) was measured with a diameter tape.

\section{HABITAT DESCRIPTION}

Detailed habitat information on lands adjacent to Lake Pend Oreille, the lower Clark Fork River, and the upper Pend Oreille River was not available, therefore, a general description of these lands was used to characterize bald eagle habitat. USFS personnel provided a description of the area based upon aerial photo interpretation and limited forest stand data for two habitat use zones: 1) shoreline zone: a $100 \mathrm{~m}$ wide band along the shoreline of the lake and rivers, 2) upland zone: a $1.6 \mathrm{~km}$ wide band adjoining the shoreline zone. The shoreline zone encompassed areas of considerable daily activity that bald eagles used for feeding, perching, and hunting. The upland zone included secondary use areas that were used for roosting and loafing, and where a higher degree of security from disturbance for bald eagles could be maintained. Both zones were subjectively divided into the same 25 units based upon major differences in topographic and habitat characteristics (Fig. 4). Each unit was described in terms of habitat type (Cooper et al. 1985), estimated percent of unforested and forested land (old-growth, mature, and younger timber classes), estimated mean height and density of upper canopy trees, most common slopes, land ownership, and proposed management plans for USFS land (U.S. Forest Service 1985).

\section{BEHAVIORAL ACTIVITY BUDGETS}

Bald eagle behavior was documented during weekly daylong observation sessions at sites of intense eagle activity. Portable blinds were used to hide the observer and minimize disturbance. Observation sites were initially chosen to correspond with eagle distribution noted in the weekly aerial censuses and were used alternately throughout the 1985-86 field season until eagle activity at a site diminished significantly. In the winter of 1986-87, eagle behavior was documented only at the mouth of Granite Creek (Fig. 5). Some sites of intense eagle activity were excluded as potential observation sites due to their inaccessibility to observers, too great a distance for observation to be effective, or a lack of suitable locations from which observations might be conducted.

Observation sessions usually began approximately 30 minutes before sunrise and were terminated after sunset when eagles were no longer present. The activity (state) of each 


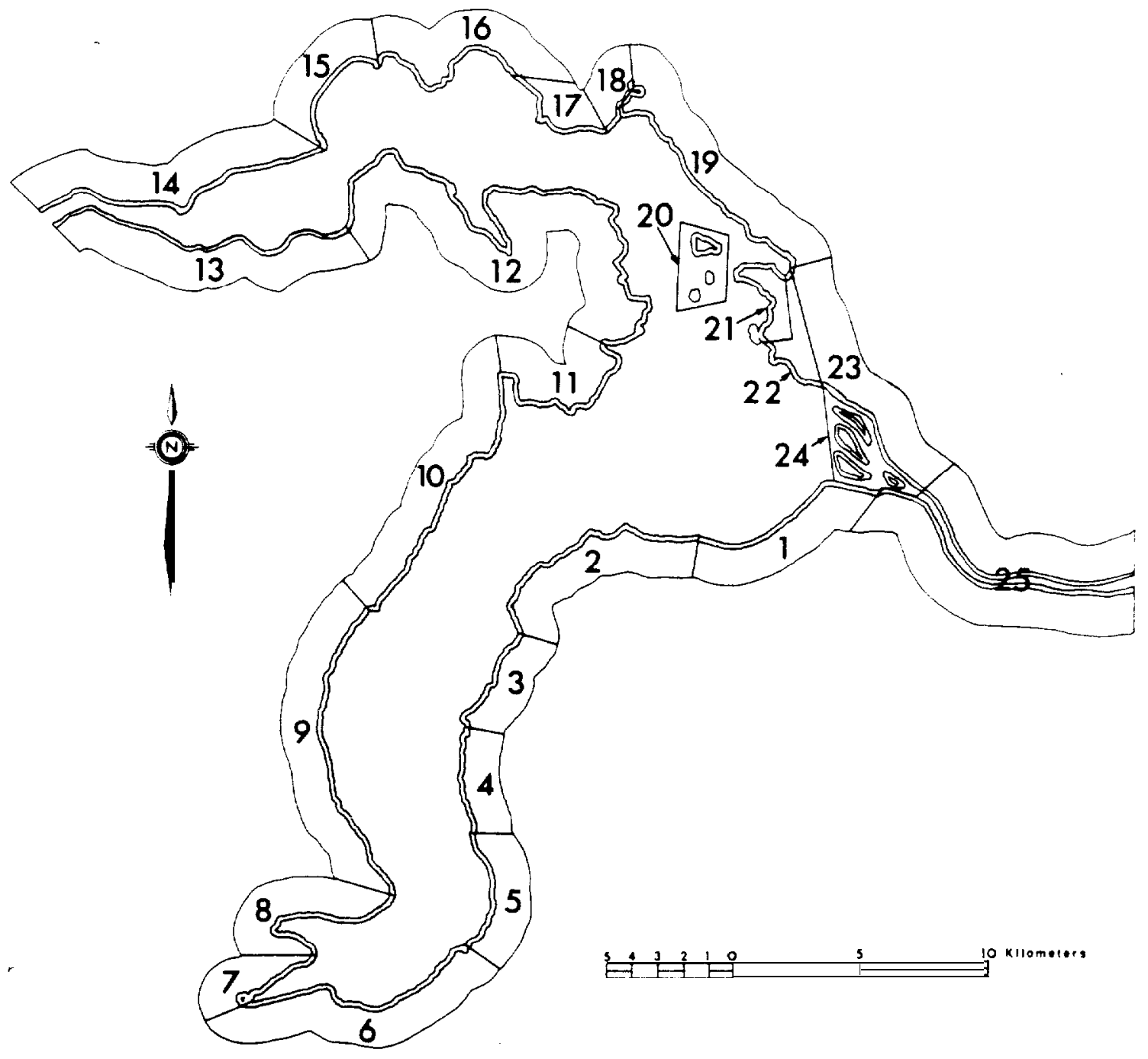

Figure 4. Map of habitat use zones on Lake Fend Oreille. 


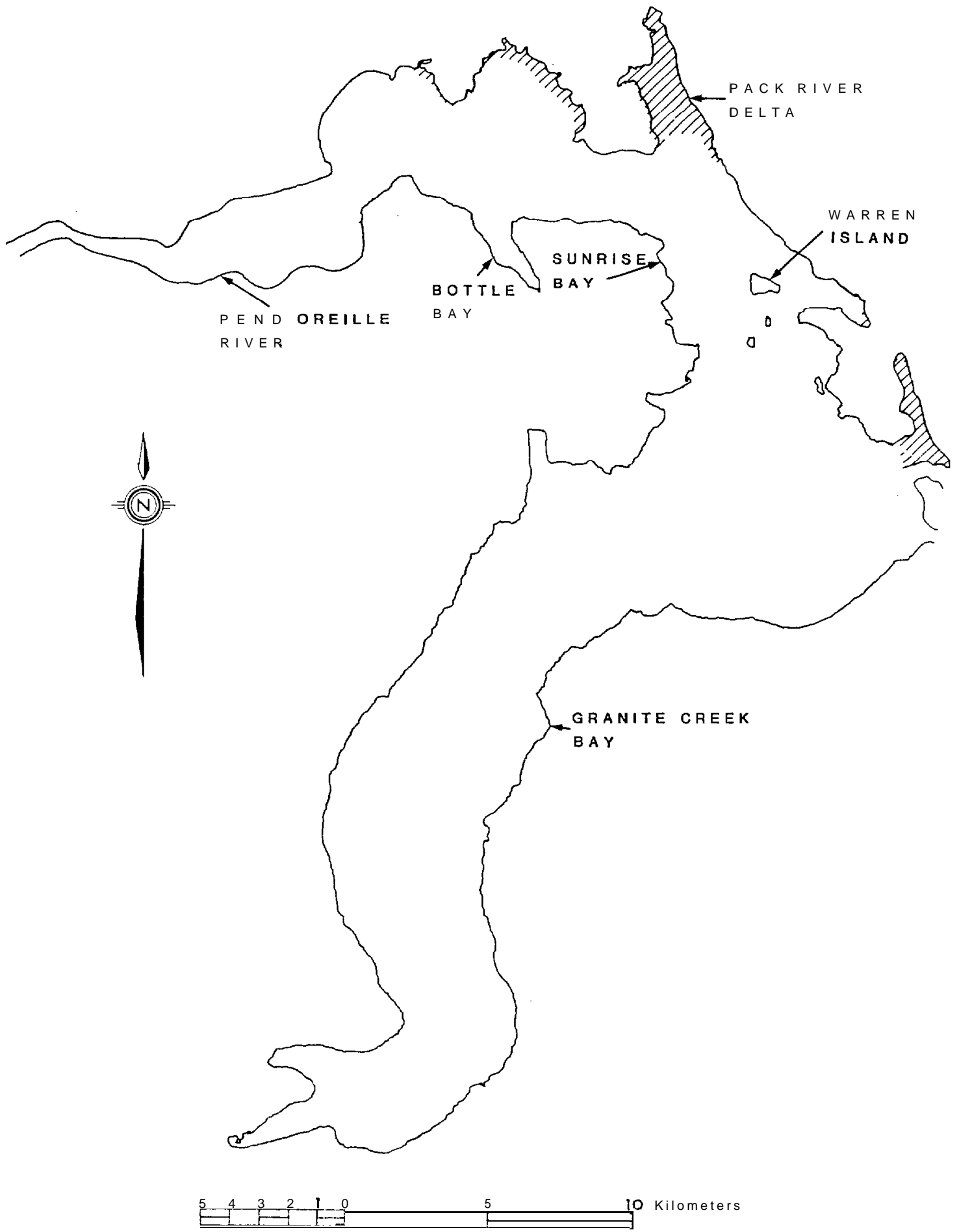

Figure 5. Locations of observation sites for bald eagle behavioral activity budgets, $1985-86$ and 1986-87. 
eagle in view was recorded (in coded form) as the observer scanned the site every five minutes (Altmann 1974) (Appendix A-4). Eagles observed were classified as either adults or subadults.

\section{FEEDING HABITS}

Foraging events of bald eagles were additionally recorded independently of the 5-min activity scan during each observation session to provide a detailed record of the frequency and success rate of capture attempts by bald eagles, and to add to a list of prey species taken by bald eagles.

Pellets of undigested food materials cast up by bald eagles at two major nocturnal roosts and remains of prey discarded by eagles at diurnal feeding perches were located by searching under roost and perch trees and by walking shoreline transects. Materials collected were labeled for laboratory analysis. Pellets were soaked in a weak (10\%) sodium hydroxide solution or soapy water to aid in separation of materials and analyzed by methods described by Errington (1932). Mammalian prey items in pellets were identified by examination of guard hairs (Stains 1958). Fish items were identified by examination of scales (Casteel 1972) and body parts (Brown 1971, Simpson and Wallace 1978).

\section{SALMON CARCASS AVAILABILITY FROM CABINET GORGE HATCHERY}

To determine the future availability to wintering bald eagles of artificially-spawned kokanee salmon processed at the Cabinet Gorge Hatchery, salmon carcasses were released into the Clark Fork River adjacent to the hatchery and their progress downstream monitored. Salmon were marked with numerically- and color-coded tags of plastic ribbon $(2 \mathrm{~cm} x$ $16 \mathrm{~cm})$ that were stapled to the opercle of each fish. Carcasses were marked at Granite Creek immediately after being artificially spawned, then packed in ice or snow, and transported to the hatchery. Live, artificially-spawned salmon were anaesthetized with MS-222 and either marked at the hatchery where they were placed in a holding pond, or at Granite Creek where they were placed in an aerated water tank and transported by truck to the hatchery.. Live salmon were allowed to expire just prior to release.., All carcasses were released $10 \mathrm{~m}$ offshore $(3-5 \mathrm{~m}$ depth) from the hatchery fish ladder at the approximate location of future releases or in mid-channel of the river ( $>15 \mathrm{~m}$ depth). 


\begin{abstract}
Movement of tagged carcasses downstream was monitored by searching from boats for those that had become stranded along the shoreline and shallows of the river. Surveys were conducted when low flows were anticipated during a minimum of three days following each release. Drift nets were positioned across two side channels to reduce survey time. Initially, surveys were conducted from the release site to the Clark Fork River delta (10 RMs), but some later surveys were terminated near the mouth of the south channel of the river ( $8 \mathrm{RMs}$ ) due to problems in safely maneuvering boats through the braided channels of the lower sections of the river, particularly at low flows. The tag number and/or color, location, percent of flesh remaining, and availability of carcasses to bald eagles were recorded for all located markers.
\end{abstract}




\section{BALD EAGLE ABUNDANCE AND DISTRIBUTION}

Total Study Area

Aerial censuses of bald eagles within the study area were conducted from 7 November 1985 to 3 April 1986 (N = 19) and from 24 October 1986 to 3 April $1987(\mathrm{~N}=23)$. In both years of the study, migrant bald eagles began to arrive in the area in late October or early November, and departed by early April (Fig. 6). Eagle numbers increased, peaked, and declined later in the concentration period in 1985-86 than in 1986-87. The number of weeks $(\mathrm{N}=22)$ that elapsed between the first and last census of greater than 25 eagles (which excludes early censuses consisting primarily of resident eagles) was equal for both years of the study, indicating concentration periods of approximately equal duration.

Peak eagle numbers in 1985-86 (274) were recorded two weeks later than in 1986-87 (429) (Table 1). The timing of the peaks is similar to that for concentrations of wintering eagles in other parts of the U.S. (Spencer 1976); weekly variations in eagle numbers as evidenced during both winters have been attributed elsewhere to weather conditions on census days, migratory movements, and availability of prey (Southern 1963, Shea 1973, Servheen 1975).

The 1985-86 peak in numbers of adults (228) occurred one week later than the subadult peak (65); peak counts occurred on the same date for both adults (364) and subadults (65) in 1986-87. Adult bald eagles outnumbered subadults in all censuses throughout both years (Figs. 7 and 8). The mean percentage of subadult bald eagles counted in 1985-86 censuses was $18.1 \%$; similar to the $18.5 \%$ counted in 1986-87 (Fig. 9). These values are lower than the 30\% subadults that is typical in wintering populations in Washington (Hancock 1964, Stalmaster et al. 1979), Utah (Edwards 1969), and Montana (McClelland 1973), and much lower than the $60 \%$ subadults found in Arizona (Grubb 1984).

Mid-January censuses of bald eagles on Lake Pend Oreille, the lower Clark Fork River below Cabinet Gorge Dam, and the upper Pend Oreille River, which were conducted as part of the National Wildlife Federation's nationwide bald eagle surveys since they were begun in 1979, increased significantly $(\underline{P}<0.050)$ in 1986 and 1987 above previous censuses. The counts in 1986 (265) and 1987 (266) were significantly higher $(\underline{P}<0.050)$ than the mean count for 1981 to $1984(\overline{\mathrm{X}}=88.4)$ (Fig. 10) (IDFG internal document). This increase may be due in small part to increased 


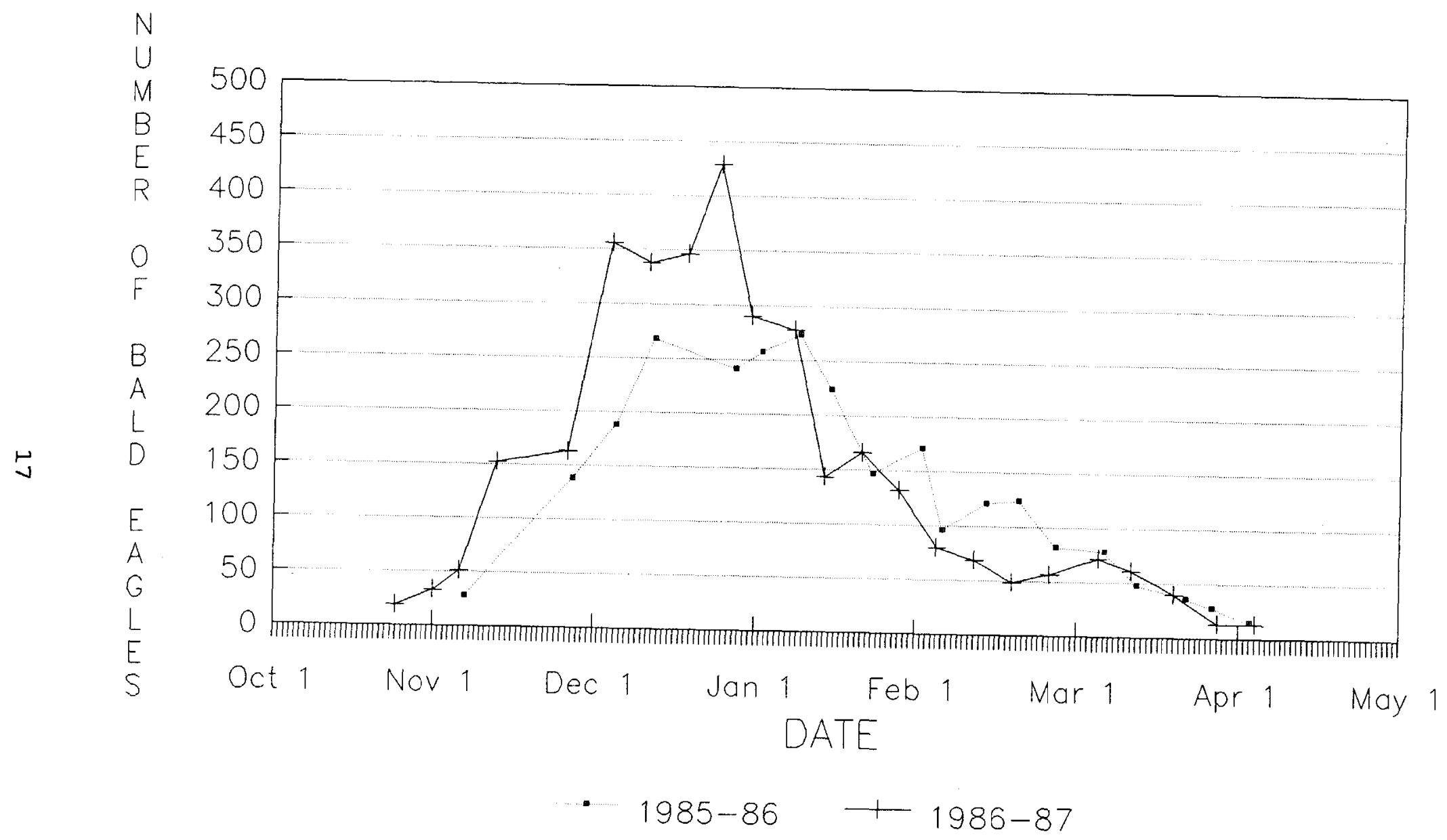
Figure 6. Numbers of bald eagles in aerial censuses of the study area,
$1985-86$ and 1986-87. 
Table 1. Peak counts of bald eagles in aerial censuses of the study area, $1985-86$ and 1986-87.

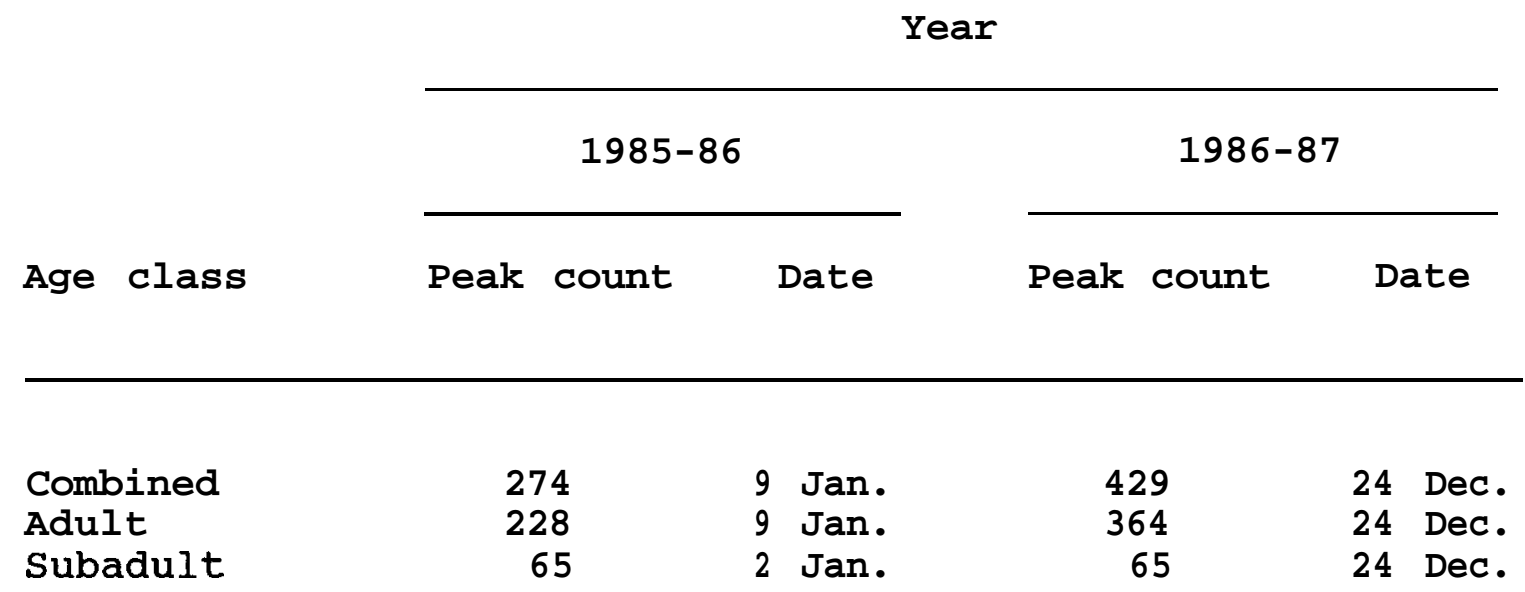




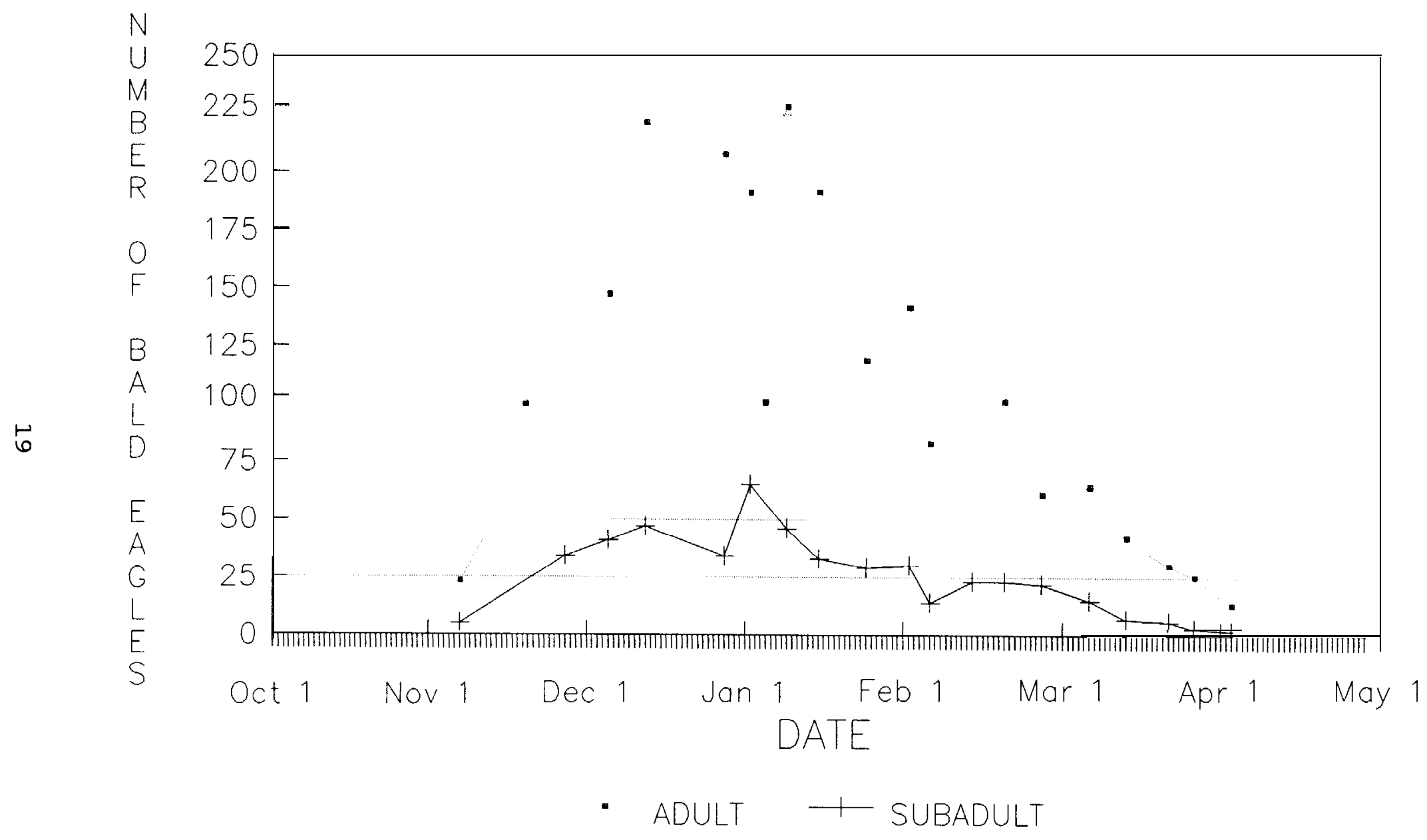

Figure 7. Numbers of adult and subadult bald eagles in aerial censuses of the study area, 1985-86. 


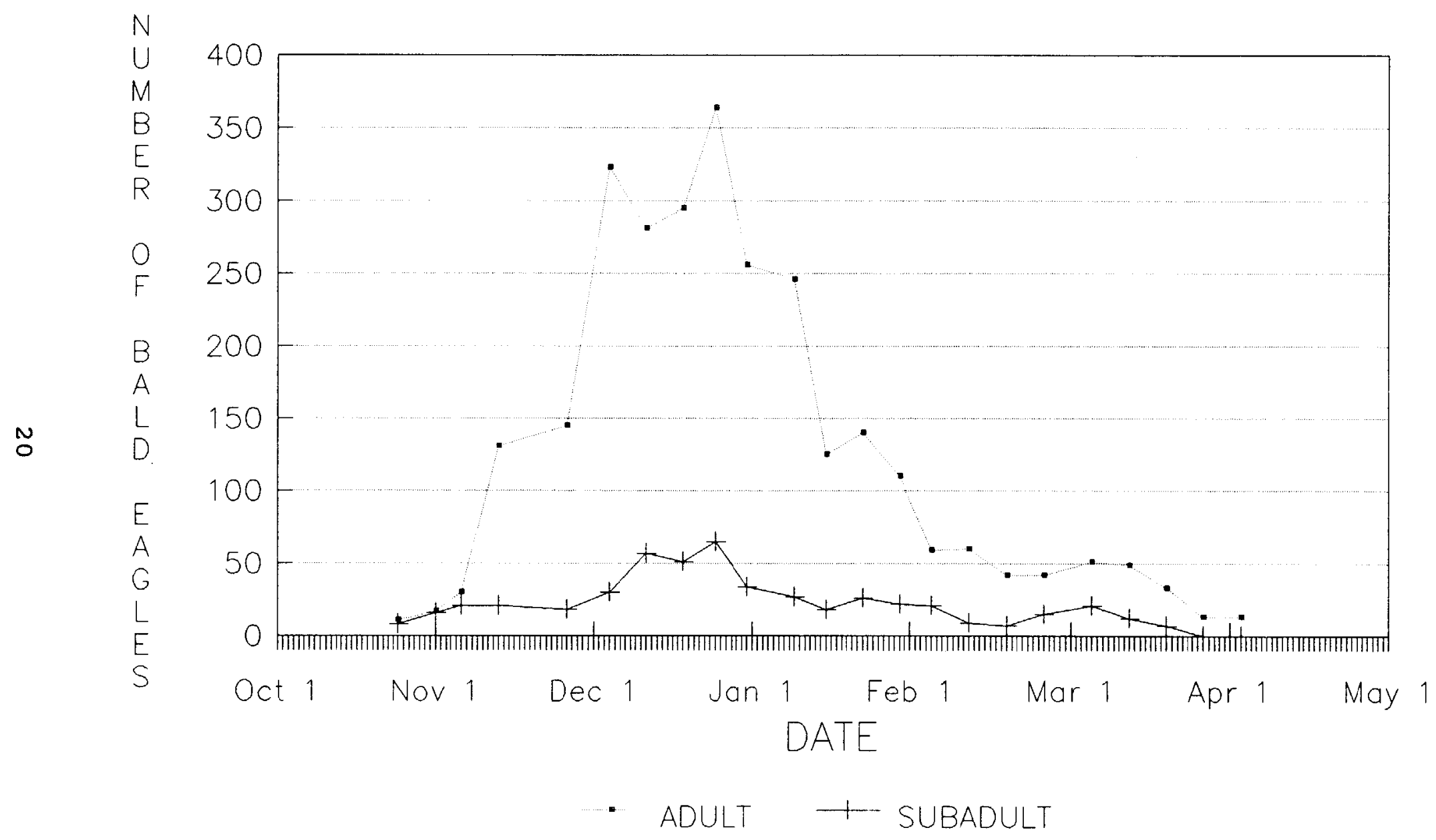

Figure 8. Numbers of actult and subadult bald eagles in aerial censuses of the study area, 1986-87. 


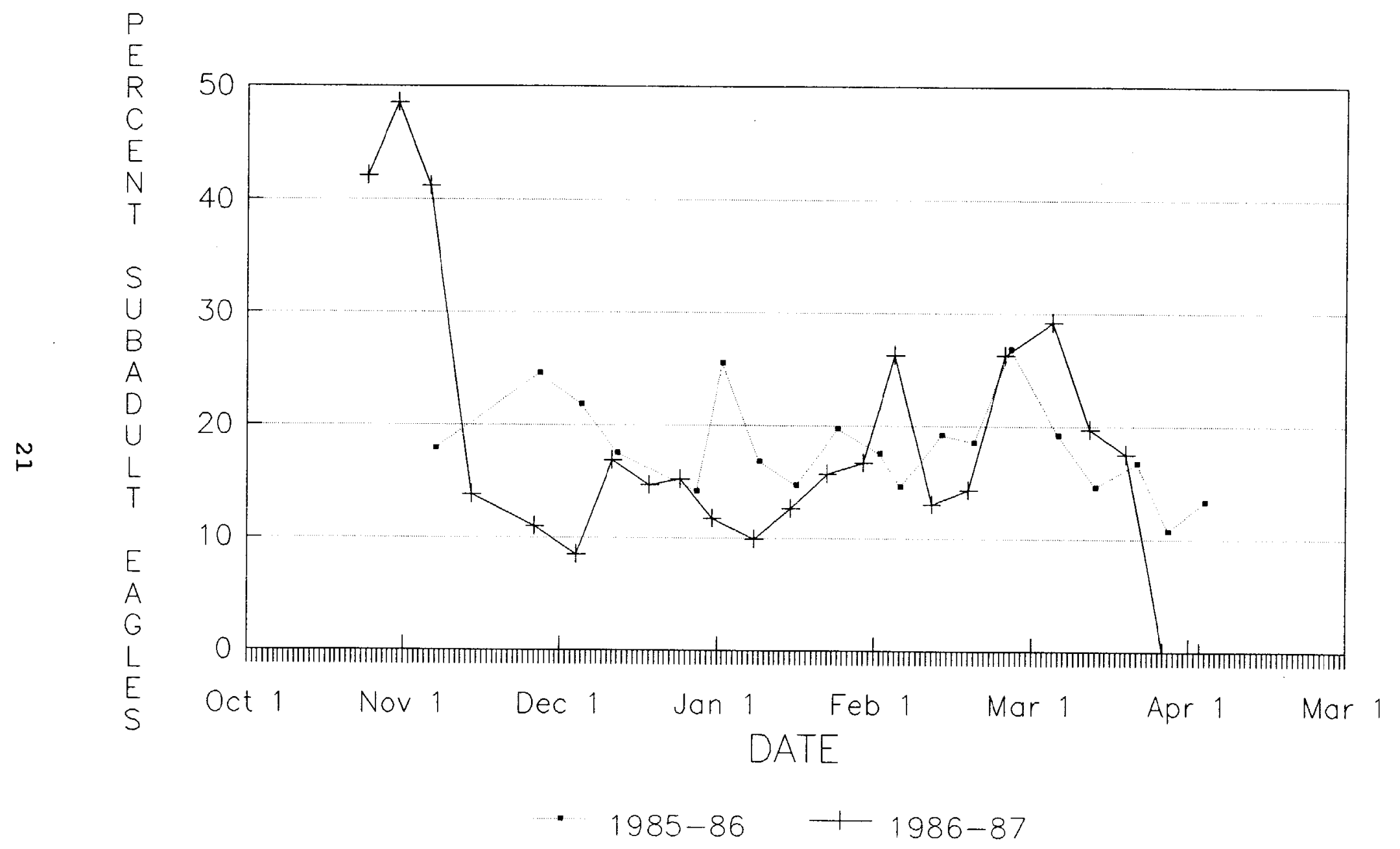

Figure 9. Percent subadult bald eagles in aerial censuses of the study area, 1985-86 and 1986-87. 


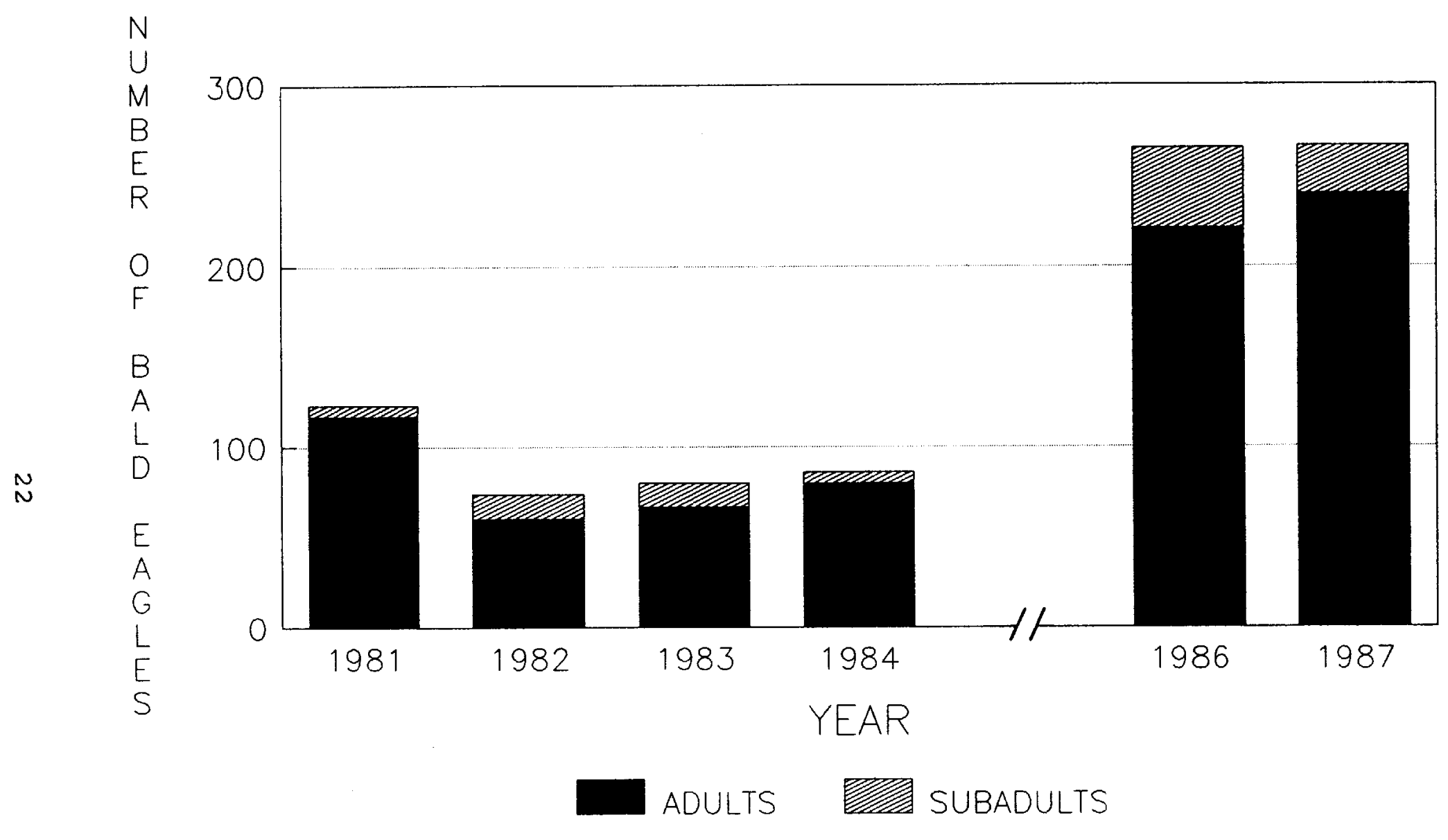

Figure 10. Mid-winter bald eagle censuses of the study area, excluding upstream of Cabinet Gorge Dam, 1981-84 and 1986-87. 
familiarity with the census route in 1986 and 1987 by those conducting the census, or by having a concentration period in which the peak in eagle numbers did not correspond to the census date, as occurred in 1987. The 1986 and $1987 \mathrm{mid}-$ January counts contributed an average of $34 \%$ of the total number of eagles counted in Idaho in the National Wildlife Federation's surveys and approximately $2 \%$ of the number counted nationwide.

Lake Pend Oreille

Most of the eagles counted in the censuses of the study area were found along the shoreline of Lake Pend Oreille in 1985-86 $(\bar{x}=74.8 \%)$ and 1986-87 ( $\bar{x}=67.0 \%)$ (Appendix $B)$. The peak census of eagles on the lake in 1985-86 was lower and occurred earlier than the peak in 1986-87 (Table 2; Fig. 11).

Areas used by bald eagles along Lake Pend Oreille were classified based on the mean number of eagles sighted along each LM in aerial censuses conducted during each of the two concentration periods (Table 3). In 1985-86, heavy use areas were restricted to 12 L.Ms in the northern half of the lake; individual IM counts ranged from 8-25 eagles per census (Fig. 12). Areas of moderate use were located throughout the remainder of the lake excluding the southwest shoreline. Nearly all other remaining LMs received light use; three LMs were not used by eagles.

In 1986-87, eagle distribution differed ( $\underline{P}=0.095)$ from 1985-86. Areas of heavy use were distributed to a lesser extent in northern Lake Pend Oreille, and were found near the mouth of Granite Creek and in the southernmost parts of the lake at Echo Bay. More LMs were heavily-used than during the previous year, but the mean number of eagles per census was similar. Individual LM counts in heavy use areas ranged from 8-39 eagles per census. Many areas classified as moderate were similar to those identified in the previous year. Light use was recorded at all but one of the remaining LMs in which no eagles were counted. Distribution of eagles per IM by winter period was significantly different between years (early: $\underline{P}<0.001$; mid-: $\underline{\mathrm{P}}=0.035$; late: $\underline{\mathrm{P}}<0.001)$.

Eagle distribution between years in the northern half of the lake was significantly different : only during early winter $(\underline{P}=0.027)$; the mean number of eagles per LM in 1985-86 censuses $(3=1.73)$ was higher than the mean in 1986-87 ( $\overline{\mathrm{x}}=1.02)$ (Fig. 13). In the southern half of the lake, significant differences were found during both early $(\underline{P}=0.025)$ and late winter $(\underline{P}<0.001)$ between years: during early winter the mean number of eagles per LM was 
Table 2. Peak counts of bald eagles in aerial censuses of Lake Pend Oreille, the lower Clark Fork River, and the upper Pend Oreille River, 1985-86 and 1986-87.

Year

$1985-86$

Location Peak count Date Peak count Date

\begin{tabular}{|c|c|c|c|c|}
\hline Lake Pend & 251 & 12 Dec. & 352 & 24 \\
\hline $\begin{array}{l}\text { Clark Fork } \\
\text { River }\end{array}$ & 34 & 2 Jan. & 48 & $\begin{array}{r}24 \\
8\end{array}$ \\
\hline Pend Oreille & 36 & 2 Feb. & 29 & 24 \\
\hline
\end{tabular}

River 


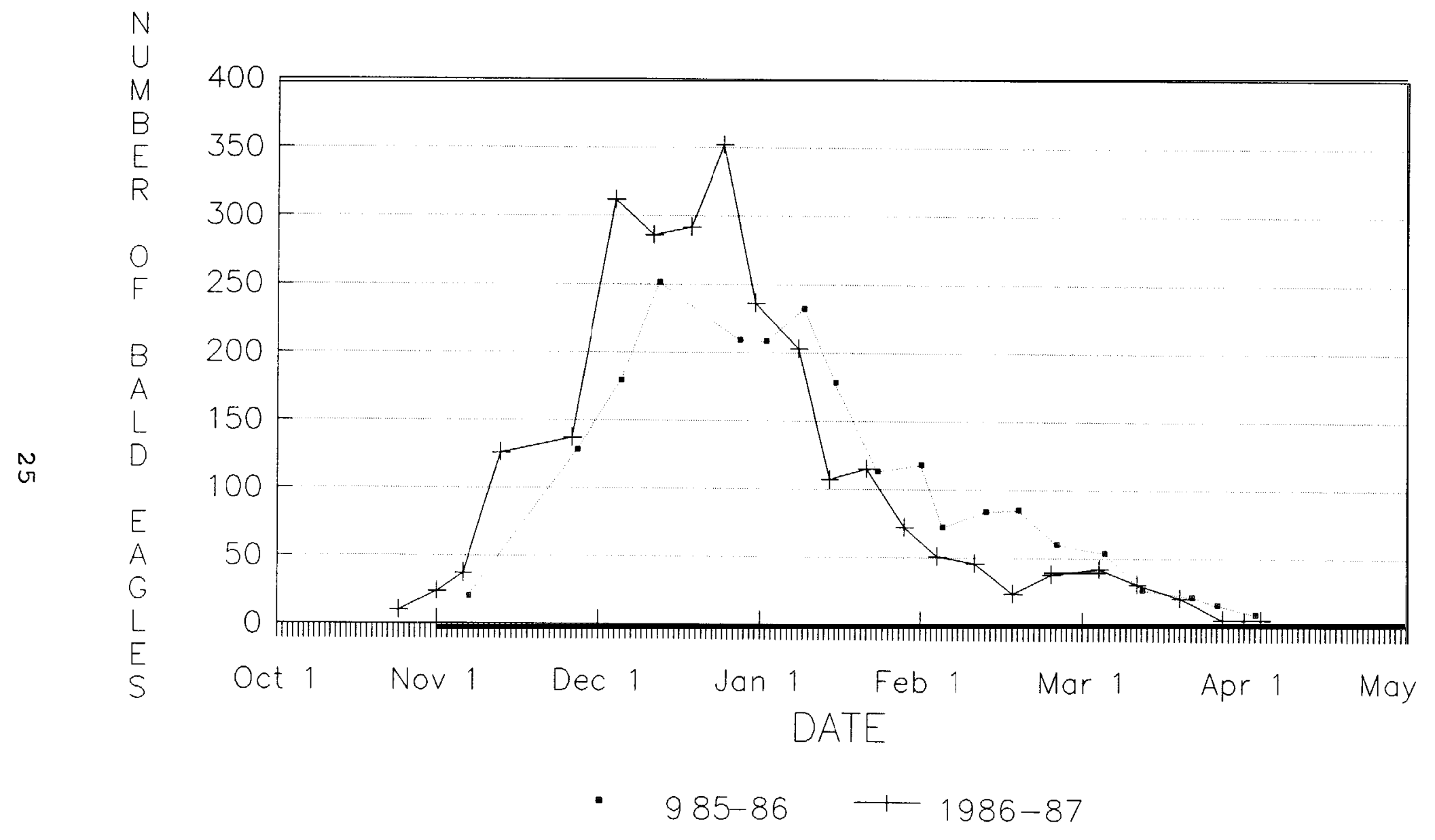

Figure 11. Numbers of bald eagles in aerial censuses of Lake Pend Oreille, 1985-86 and 1986-87. 
Table 3. Description of bald eagle use areas by lake-mile LM) on Lake Pend Oreille, 1985-86 and 1986-87.

\begin{tabular}{|c|c|c|c|c|c|}
\hline \multicolumn{2}{|c|}{ Intensity of use } & \multicolumn{2}{|r|}{$1985-86$} & \multicolumn{2}{|r|}{$1986-87$} \\
\hline class & $\begin{array}{l}\text { Mean \# eagles } \\
\text { /census/LM }\end{array}$ & \# LMs & $\begin{array}{l}\text { Mean \# eagles } \\
\text { /census/LM }\end{array}$ & \# LMs & $\begin{array}{l}\text { Mean \# eagles } \\
\text { /census/LM }\end{array}$ \\
\hline $\begin{array}{l}\text { Heavy } \\
\text { Moderate } \\
\text { Light }\end{array}$ & $\begin{array}{r}>2 \\
1-2 \\
<1\end{array}$ & $\begin{array}{l}12 \\
25 \\
74\end{array}$ & $\begin{array}{l}3.4 \\
1.4 \\
0.4\end{array}$ & $\begin{array}{l}15 \\
19 \\
77\end{array}$ & $\begin{array}{l}3.1 \\
1.4 \\
0.4\end{array}$ \\
\hline
\end{tabular}




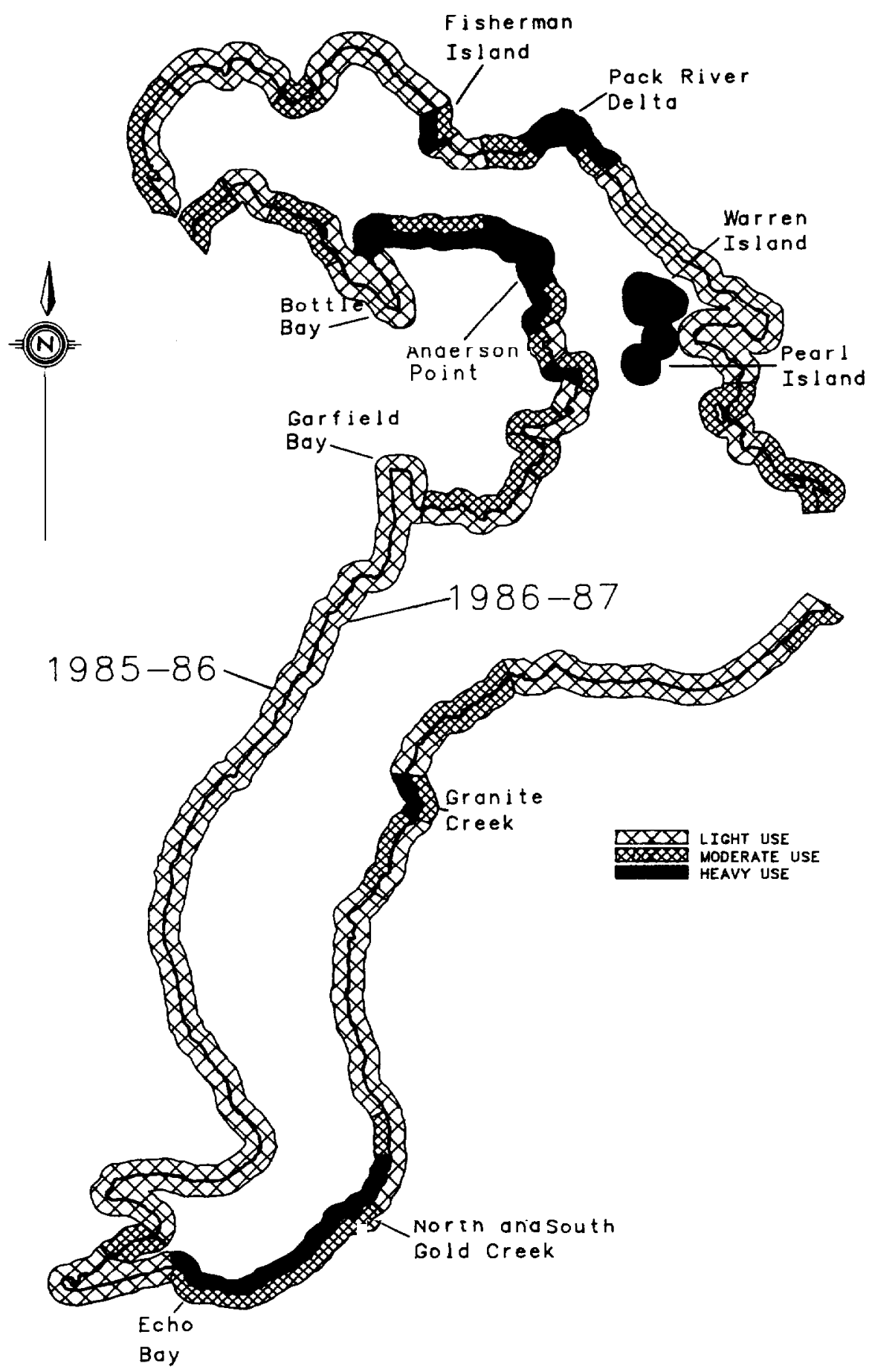

Figure 12. Distribution of bald eagle use areas on Lake Pend Oreille, 1985-86 and 1986-87. 


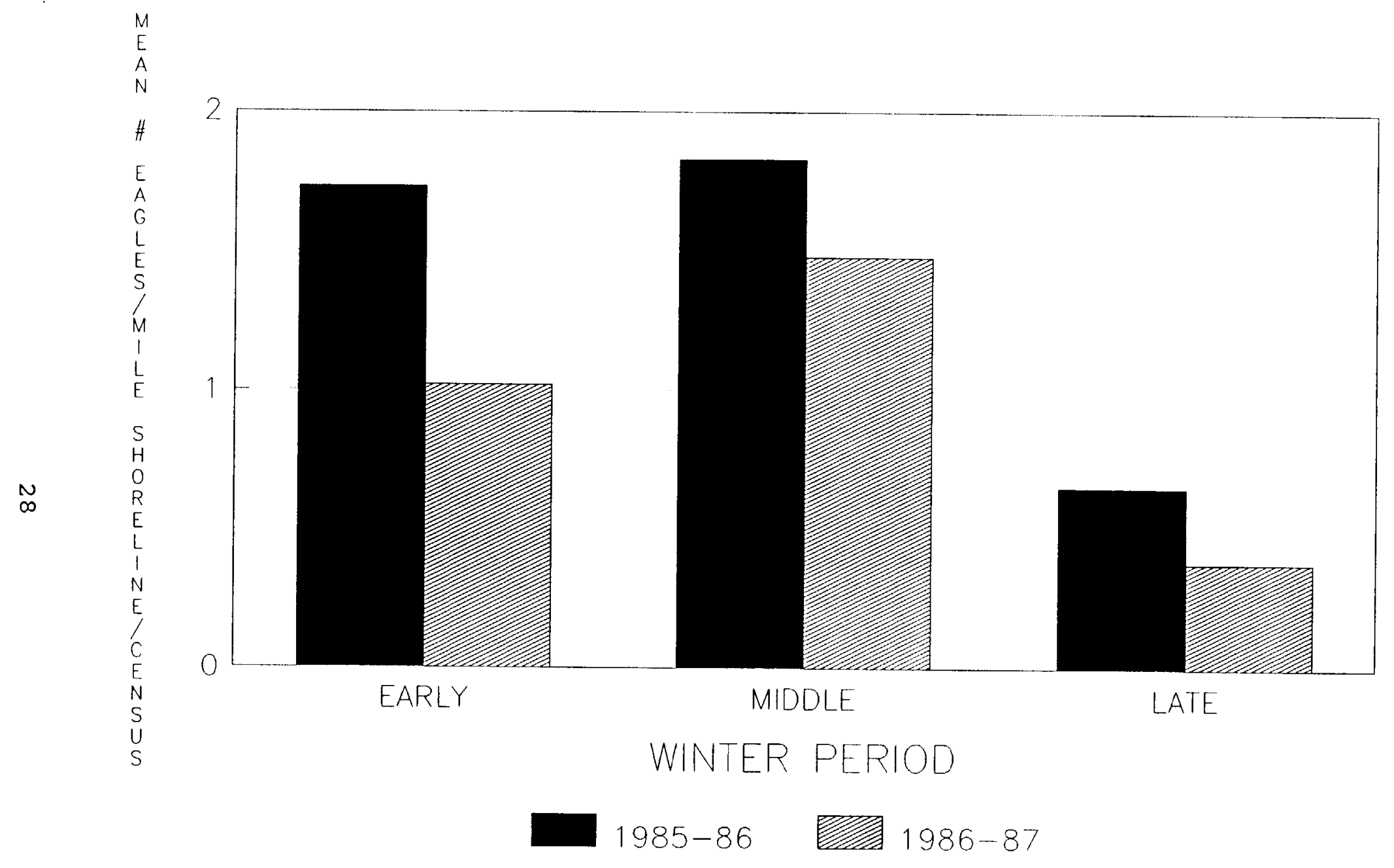

Figure 13. Mean number of bald eagles per mile shoreline on northern Lake Pend Oreille, 1985-86 and 1986-87. 
lower in 1985-86 ( $\bar{x}=0.88)$ than in 1986-87 $(\bar{x}=1.30)$, but higher during late winter in 1985-86 $(\bar{x}=0.14)$ than in 1986-87 ( $\bar{x}=0.07) \quad($ Fig. 14).

Seasonal changes in eagle distribution appeared to be associated with prey availability. Large numbers of Lake Superior whitefish that died from causes associated with spawning stress in the northern parts of the lake during early winter in 1985-86 (Ned Horner, personal communication, 1987) provided an abundant food source for eagles in this area; minimal whitefish mortality was observed in 1986-87. Greater utilization of spawned-out kokanee salmon during early winter of 1986-87 than in the previous winter in the south and southeast reaches of the lake along both the shoreline and at the mouth of tributaries was indicated by increased eagle numbers at these locations; kokanee salmon escapement in the lake was similar in $1985(366,000)$ and $1986(322,000)$ (Bowles et al. 1987). Higher minimum temperatures in 1986-87 which prevented the formation of large areas of ice in the northern bays as occurred the previous year, contributed to greater waterfowl numbers in this part of the lake and increased use of waterfowl as part of the eagles' diet in mid- to late winter.

\section{Clark Fork River}

Eagle numbers on the Clark Fork River averaged $14.4 \%$ of the study area censuses in 1985-86 and 21.3\% in 1986-87 and followed the same general pattern of use as the study area totals (Fig. 15). The peak count in 1985-86 (34) was lower than the peak in 1986-87 (48).

Most bald eagles on the river were observed along the 11 RMs between the delta and Cabinet Gorge Dam in both 1985-86 (60.5\%) and in 1986-87 (62.7\%) (Fig. 16). The preference of this section of river was probably due to the relative lack of river ice that would limit food availability, and the presence of migrating kokanee salmon whose travel upstream beyond the dam was prevented. Significantly more $(\underline{P}=0.008)$ eagles were counted in 1986-87 censuses than in the previous year. This increase corresponded to greater numbers of kokanee salmon that migrated up the river in this area in 1986-87 to spawn in the Lightning Creek/Spring Creek drainage (RM 142) and adjacent to the Cabinet Gorge Hatchery (RM 150) (Bowles et al. 19.87).

\section{Pend Oreille River}

The number of eagles counted on the upper Pend Oreille River made up an average of $10.6 \%$ of the 1985-86 censuses of the study area and $11.7 \%$ of the 1986-87 censuses. The peak census in 1985-86 occurred much later than the peak the following year (Table 2; Fig. 17). 


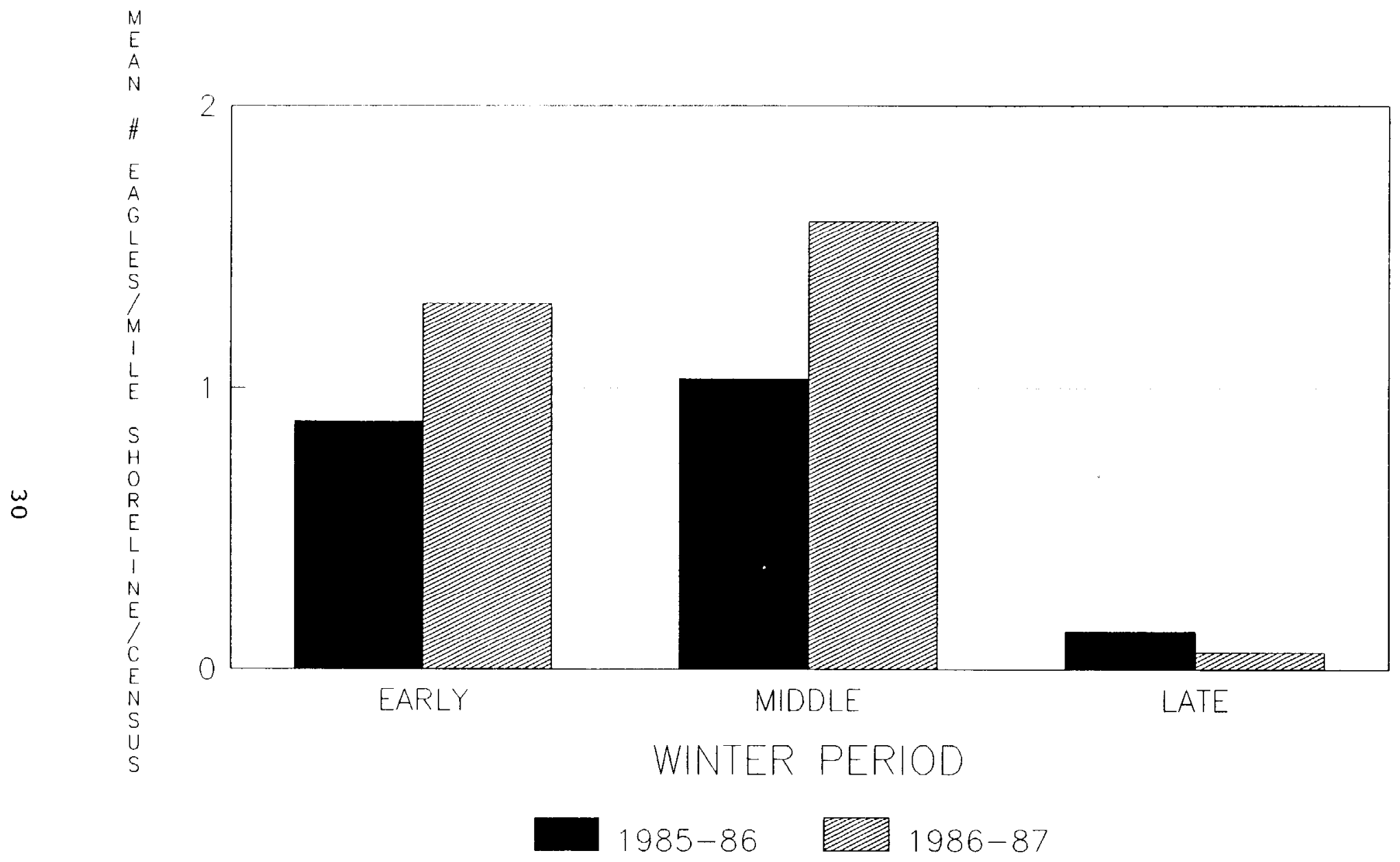

Figure 14. Mean number of bald eagles per mile shoreline on southern Lake Pend Oreille, 1985-86 and 1986-87. 


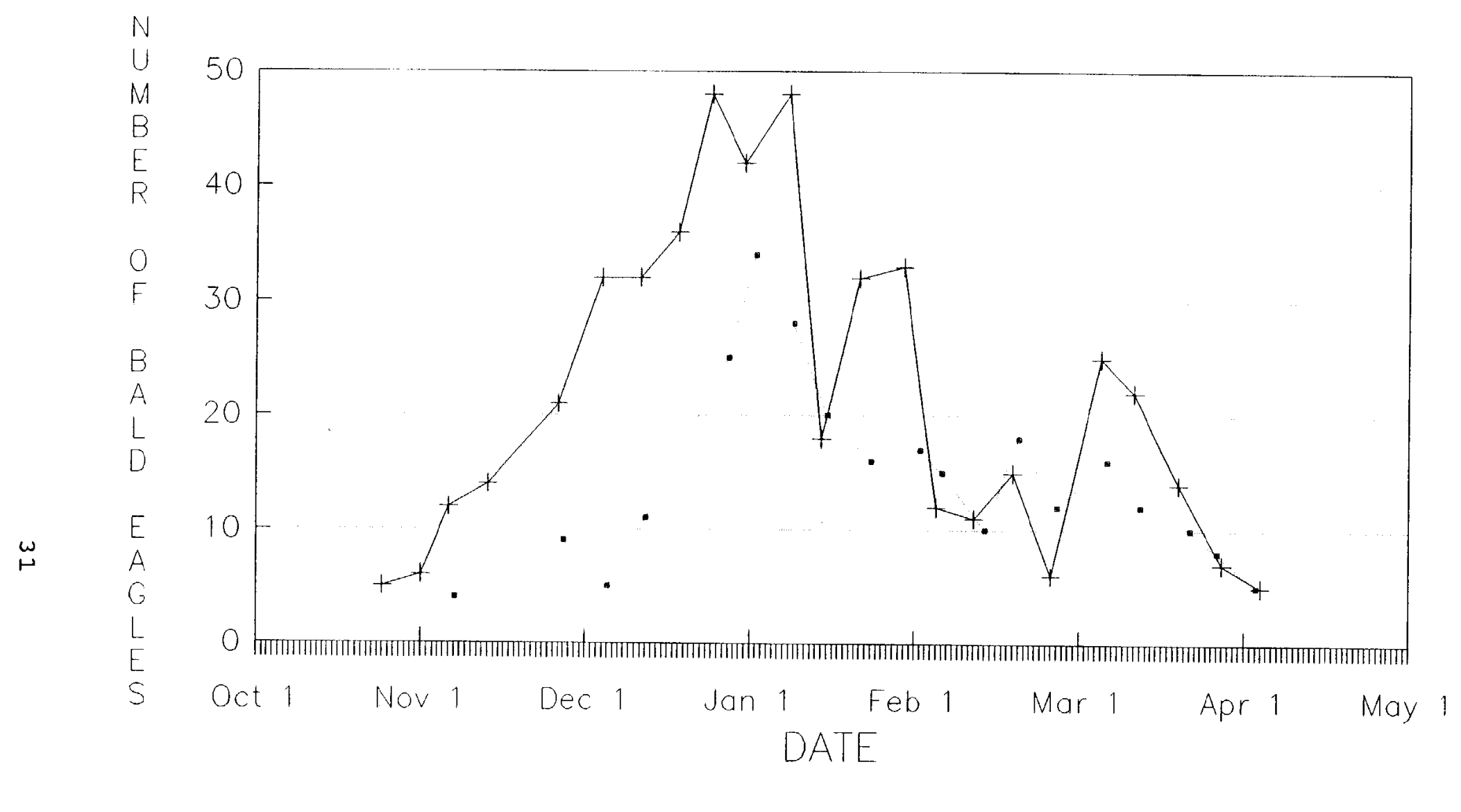

Figure 15. Numbers of bald eagles in aerial censuses of the lower clark Fork River, $1985-86$ and 1986-87. 


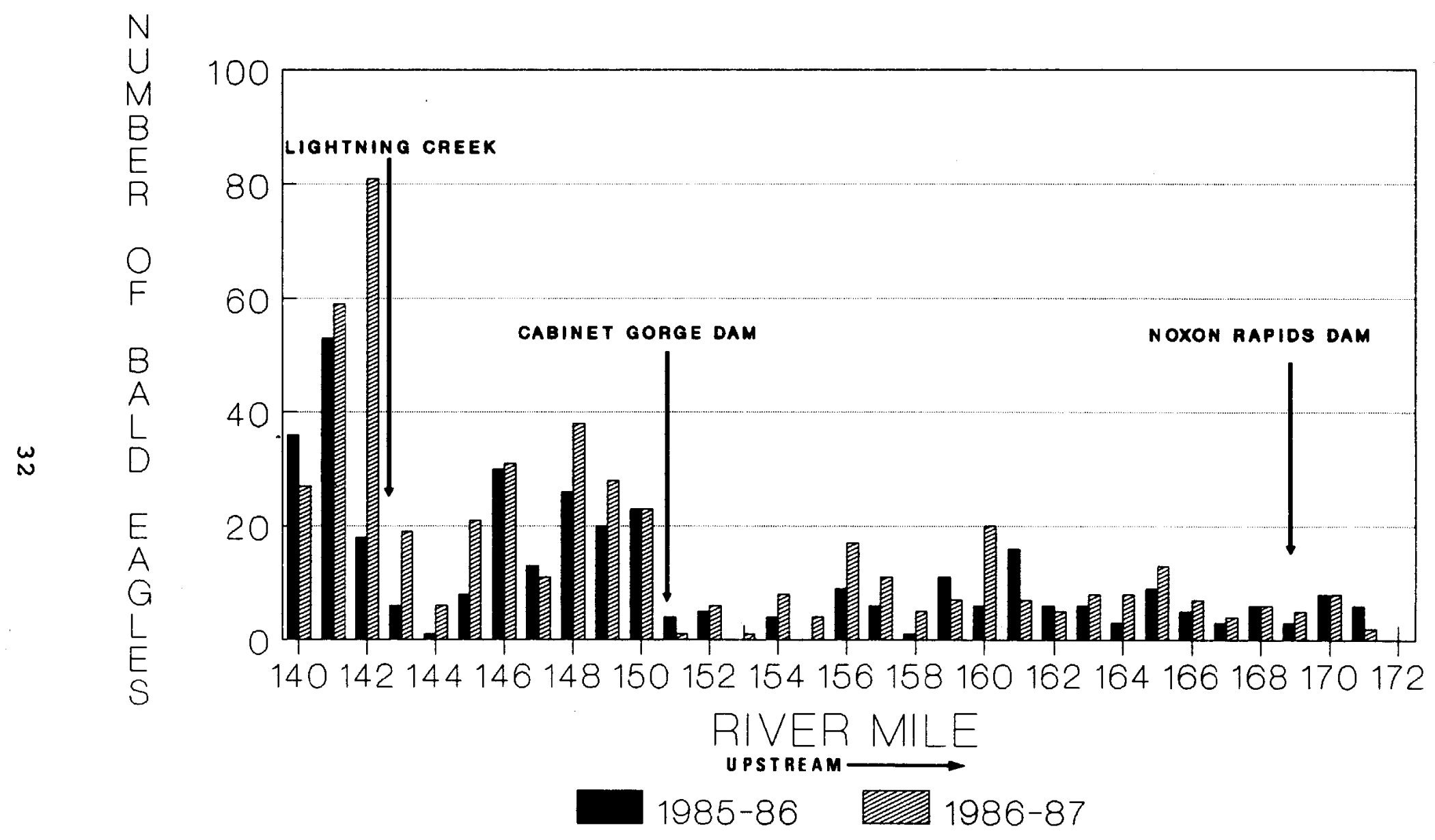

Figure 16. Distribution of total numbers of bald eagles in aerial censuses of the lower Clark Fork River, 1985-86 and 1986-87. 


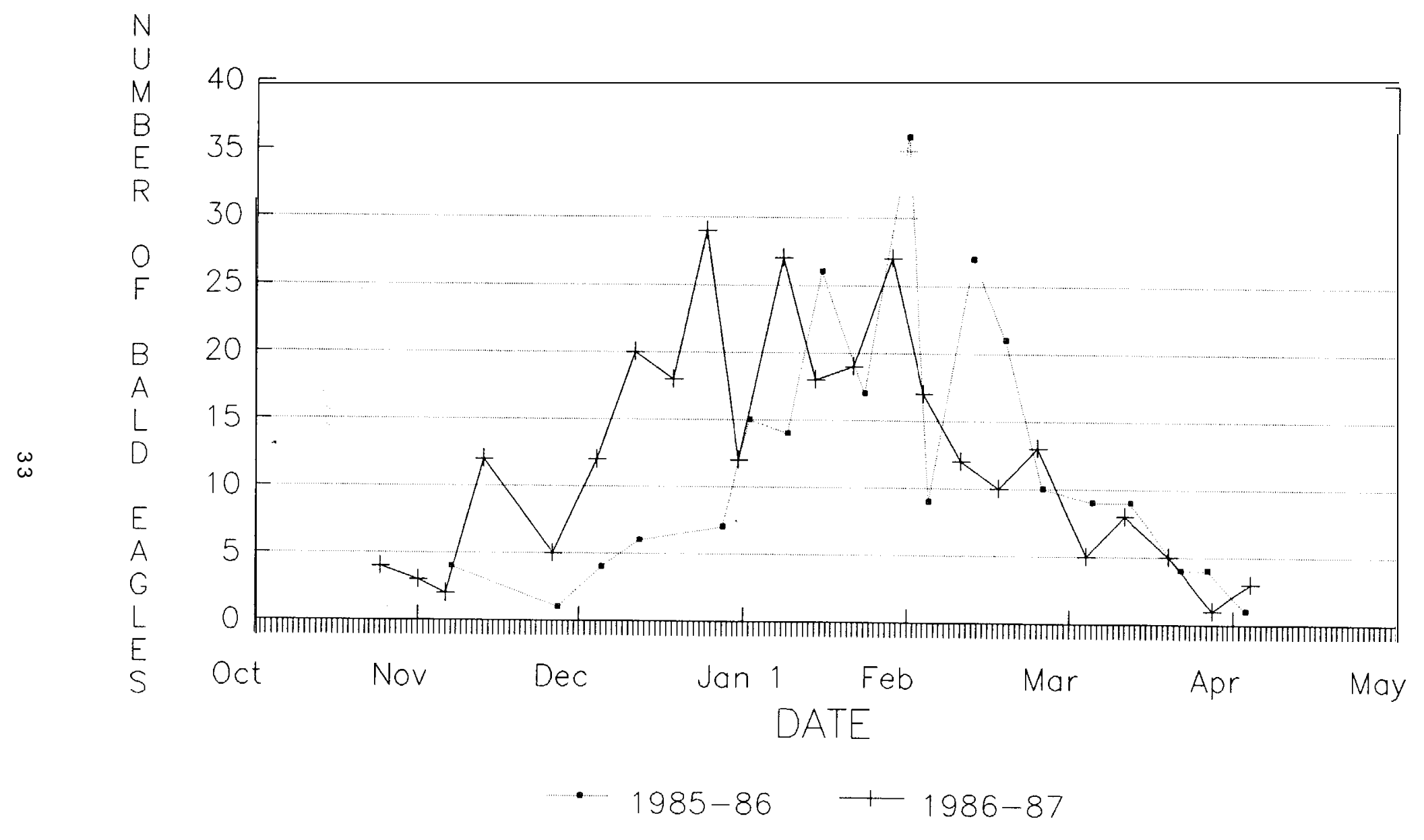

Figure 17. Numbers of bald eagles in aerial censuses of the upper Pend Oreille River, 1985-86 and 1986-87. 
Distribution of bald eagles on the upper Pend Oreille River was similar during both concentration periods (Fig. 18); counts differed significantly $(\underline{P}=0.008)$ only along RM 109. More open water and large numbers of waterfowl may have been responsible for the increase in eagle numbers on the river in 1986-87.

Monthly censuses of the lower Pend Oreille River from Smith Creek downstream to Albeni Falls Dam (N $=8)$ that were begun in February 1986 indicated low numbers of eagles in this area during most of the sample periods (Fig. 19).

\section{CAPTURE AND MOVEMENTS OF BALD EAGLES}

Six adult and two subadult bald eagles were captured, measured, and equipped with radio-transmitters during the 1985-86 concentration period (Table 4; Appendix C). Residencies within the study area after capture ranged from 1 to 35 days $(\bar{x}=13.9)$ in 1985-86. Residencies of four eagles that returned in 1986-87 ranged from 27 to 113 days $(\overline{\mathrm{X}}=58.3)$. Eagle residencies were not strongly related to the date of the peak aerial census in 1985-86 or 1986-87 (Figs. 20 and 21). In 1986-87, two transmitter-equipped eagles arrived before the peak census; two arrived after the peak. In both years of the study, all transmitterequipped eagles departed after the peak census. Departure dates of the four bald eagles that returned to the study area in 1986-87 occurred well after the peak census in 1985$86(\bar{x}=61.0$ days $)$ and $1986-87(\bar{x}=66.5$ days $)$.

Eagle \#01

The first eagle equipped with a transmitter, \#01, was an adult captured at Garfield Bay on Lake Pend Oreille at $0804 \mathrm{~h}$ on 23 January 1986 (Fig. 22). Subsequent monitoring revealed two days' movement north to Bottle Bay, then west along the upper Pend Oreille River near Smith Creek to the Muskrat Lake area where travel was more limited for the next 12 days. On 8 February, it flew northeast approximately $21 \mathrm{~km}$, remaining in this location near the Pack River along Berry Creek until 10 February, the last day a telemetry signal was received. On 17 February and again on 2 March, eagle \#01 was sighted with other eagles at Tule Lake National Wildlife Refuge, California, $15 \mathrm{~km}$ south of the Oregon border, a distance " of approximately $1,185 \mathrm{~km}$ southwest of Lake Pend Oreille.

Eaqle \#02

Eagle \#02, an adult, was captured on 29 January 1986 at $1132 \mathrm{~h}$ at Garfield Bay and remained near the bay for the next five days (Fig. 23). On 5 February, it flew to the Pend Oreille River, continuing its flight to the west the 


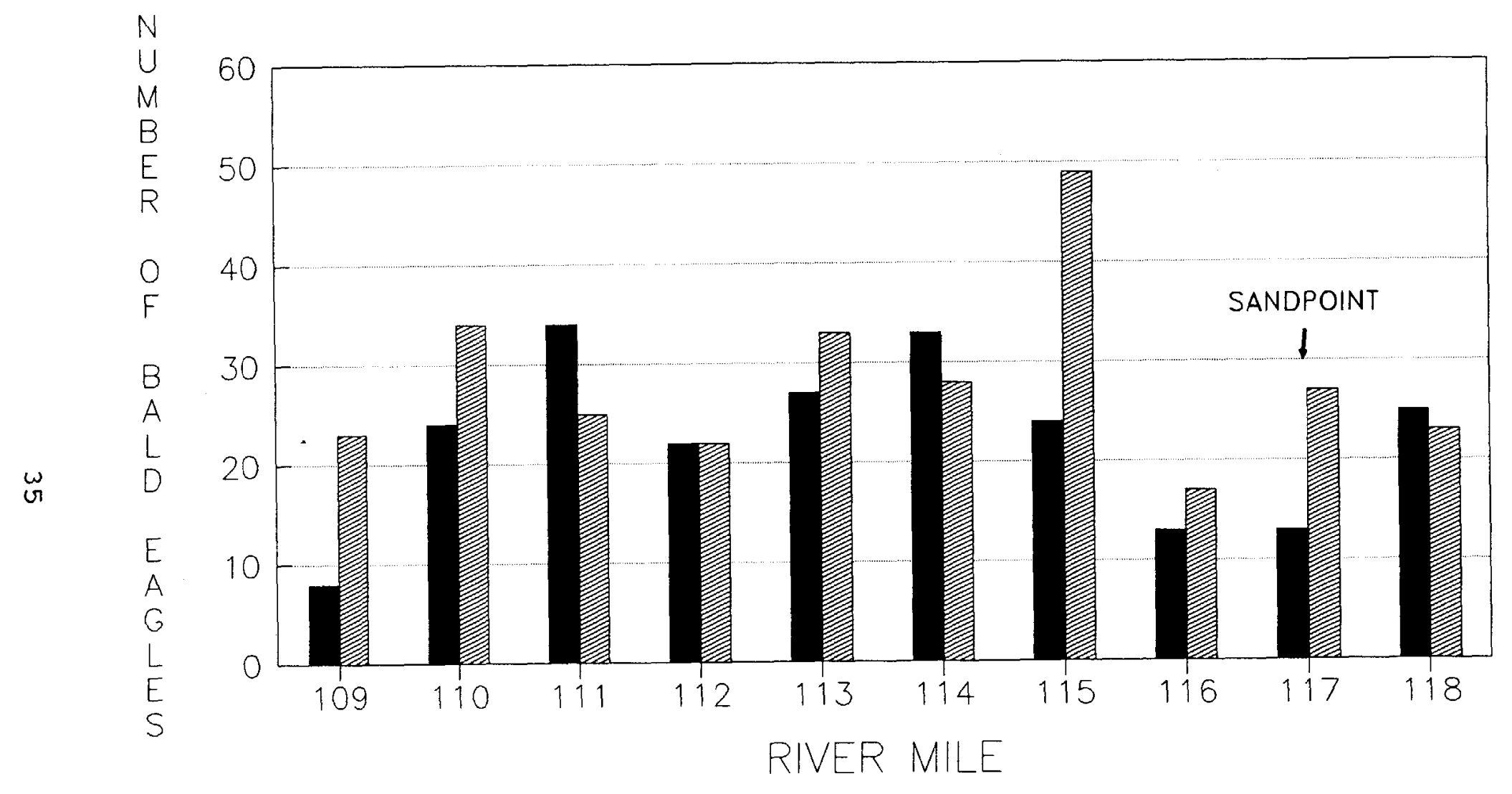

1985-86 翌 $1986-87$

Figure 18. Distribution of total numbers of bald eagles in aerial censuses of the upper Pend oreille River, 1985-86 and 1986-87. 


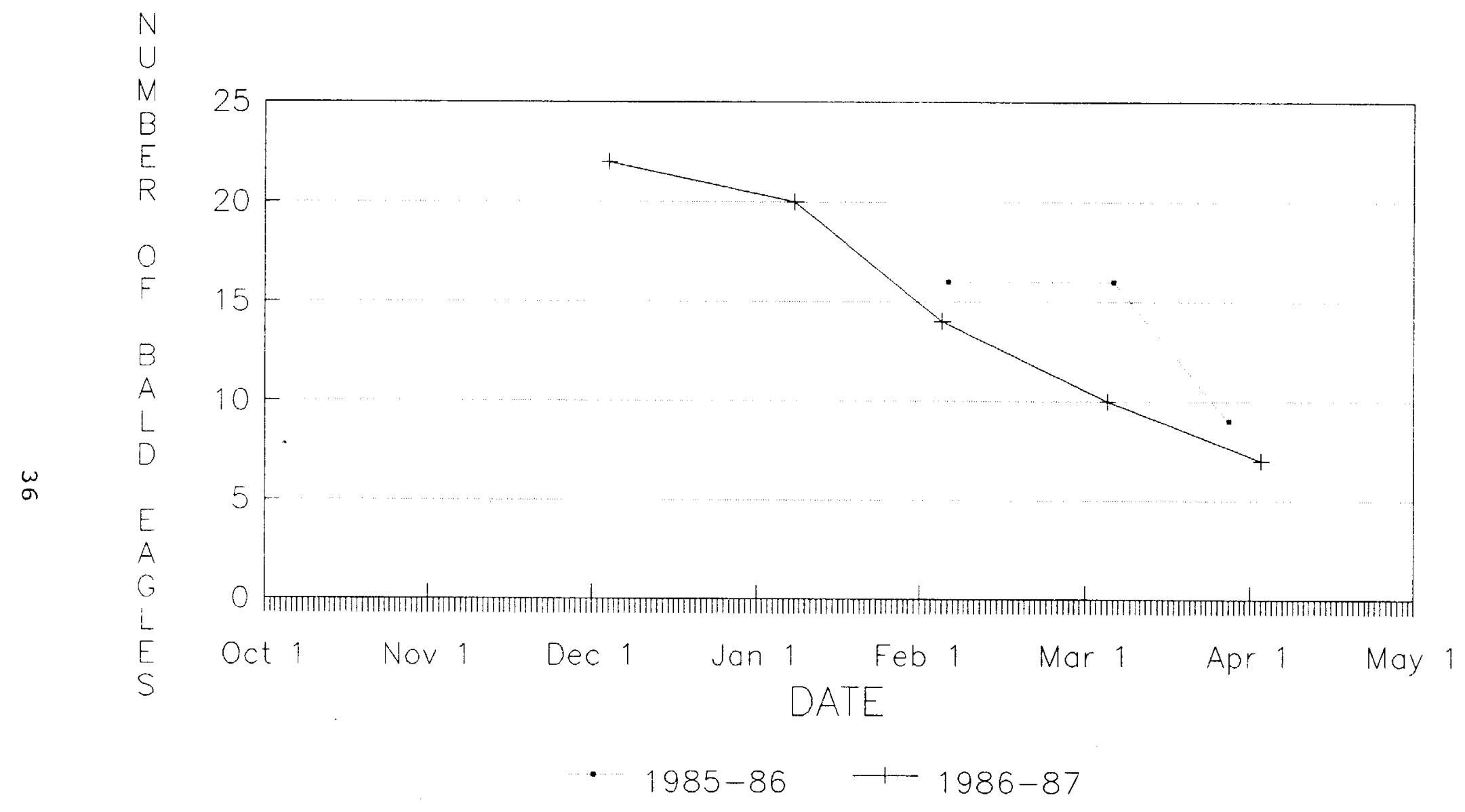

Figure 19. Numbers of bald eagies in aerial censuses of the Pend Oreille River from Smith Creek to Albeni Falls Dam, 1985-86 and 1986-87. 
Table 4. Age classes, capture dates, and residencies of transmitter-equipped bald eagles on Lake Pend Oreille, 1985-86 and 1986-87.

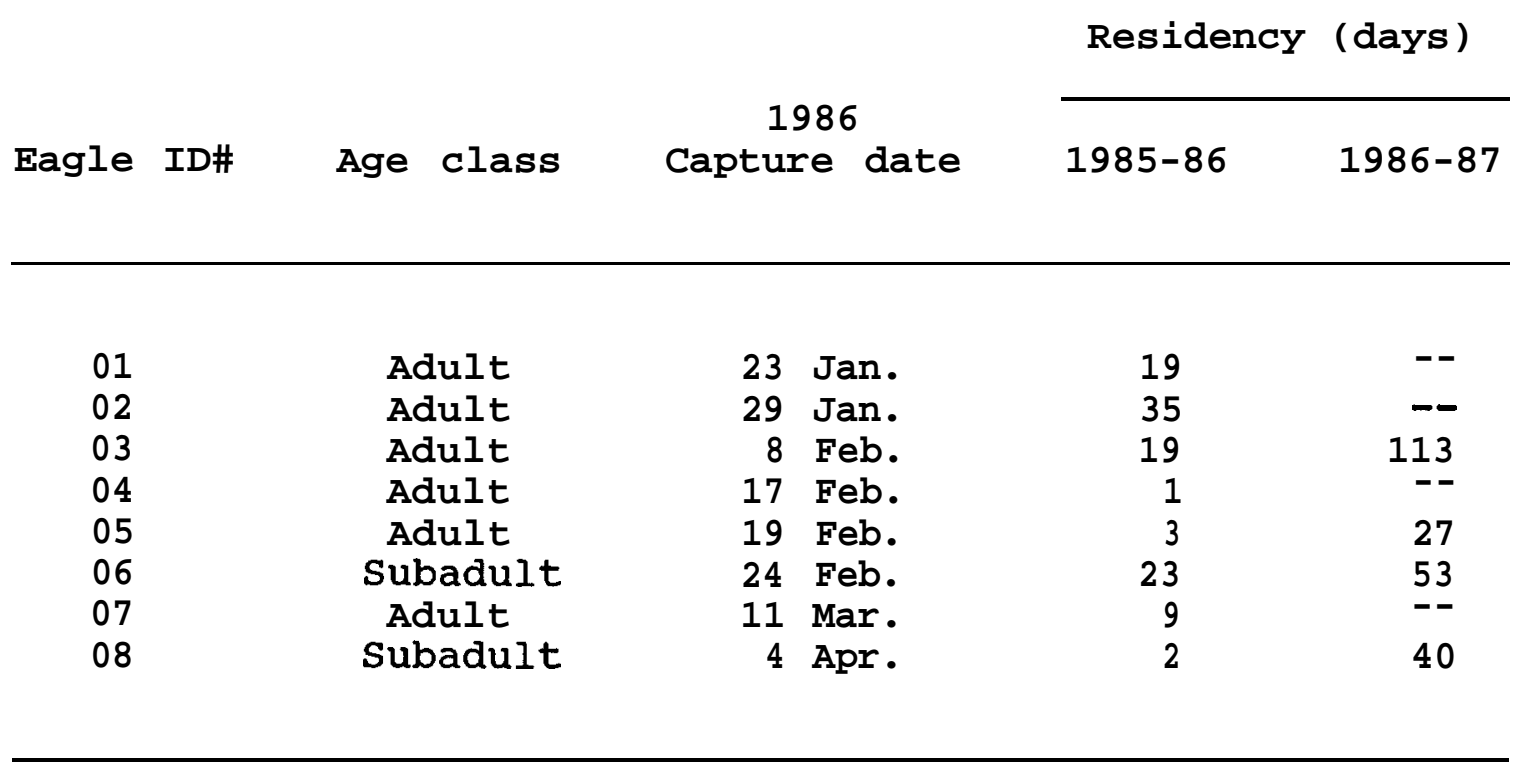




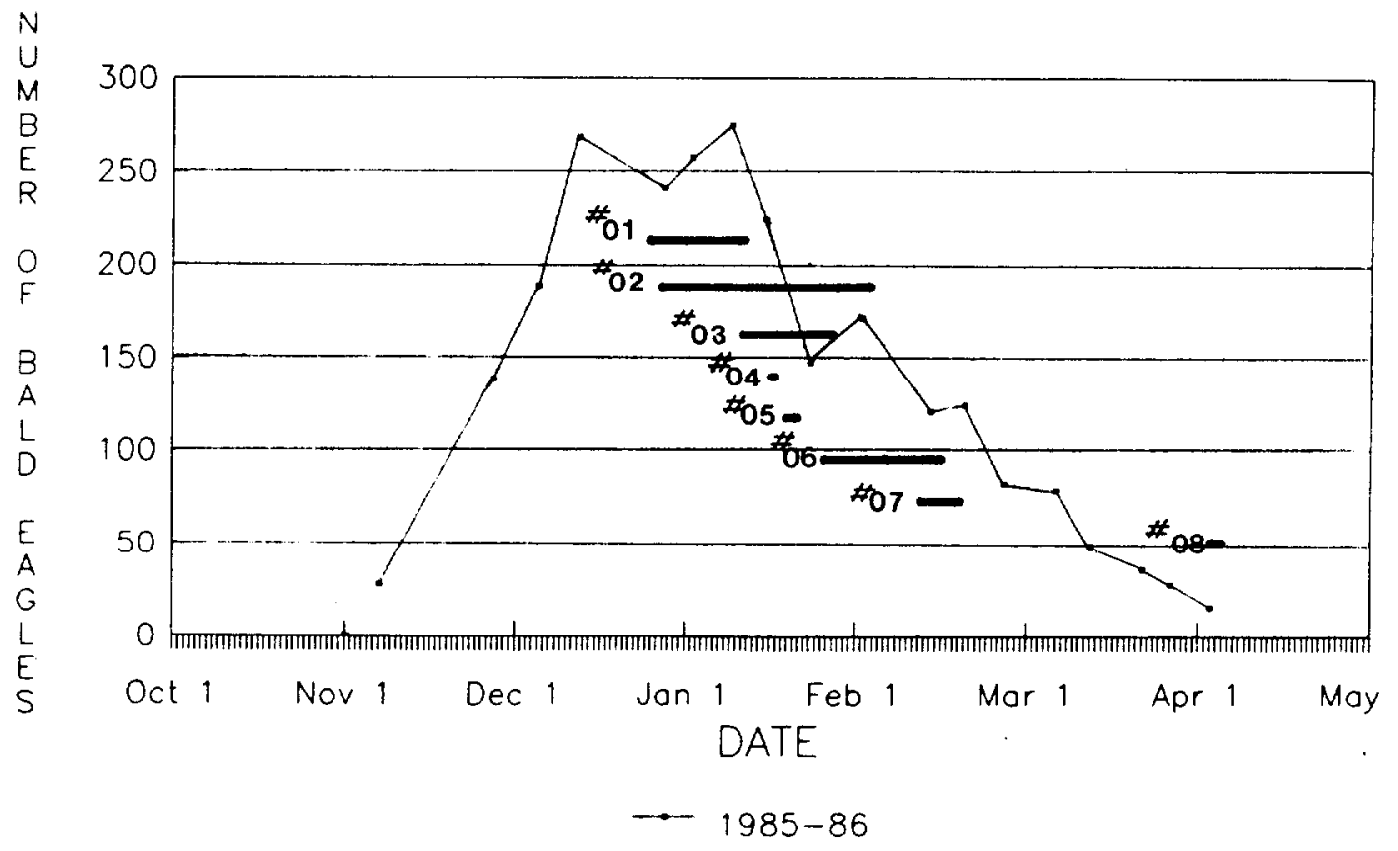

Figure 20. Numbers of bald eagles in aerial censuses and residencies of transmitter-equipped bald eagles, 1985-86.

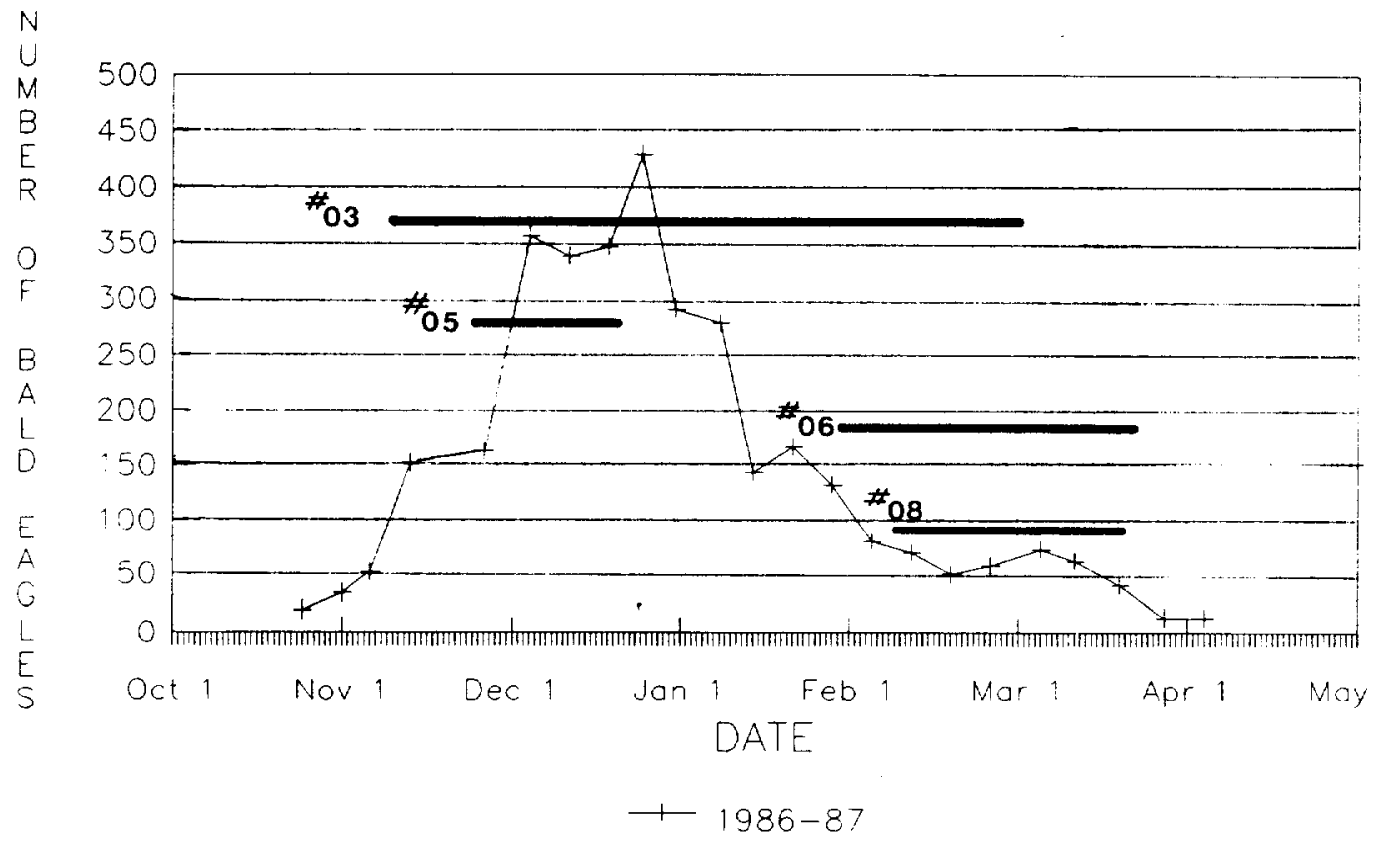

Figure 21. Numbers of bald eagles in aerial censuses and residencies of transmitter-equipped bald eagles, 1986-87. 


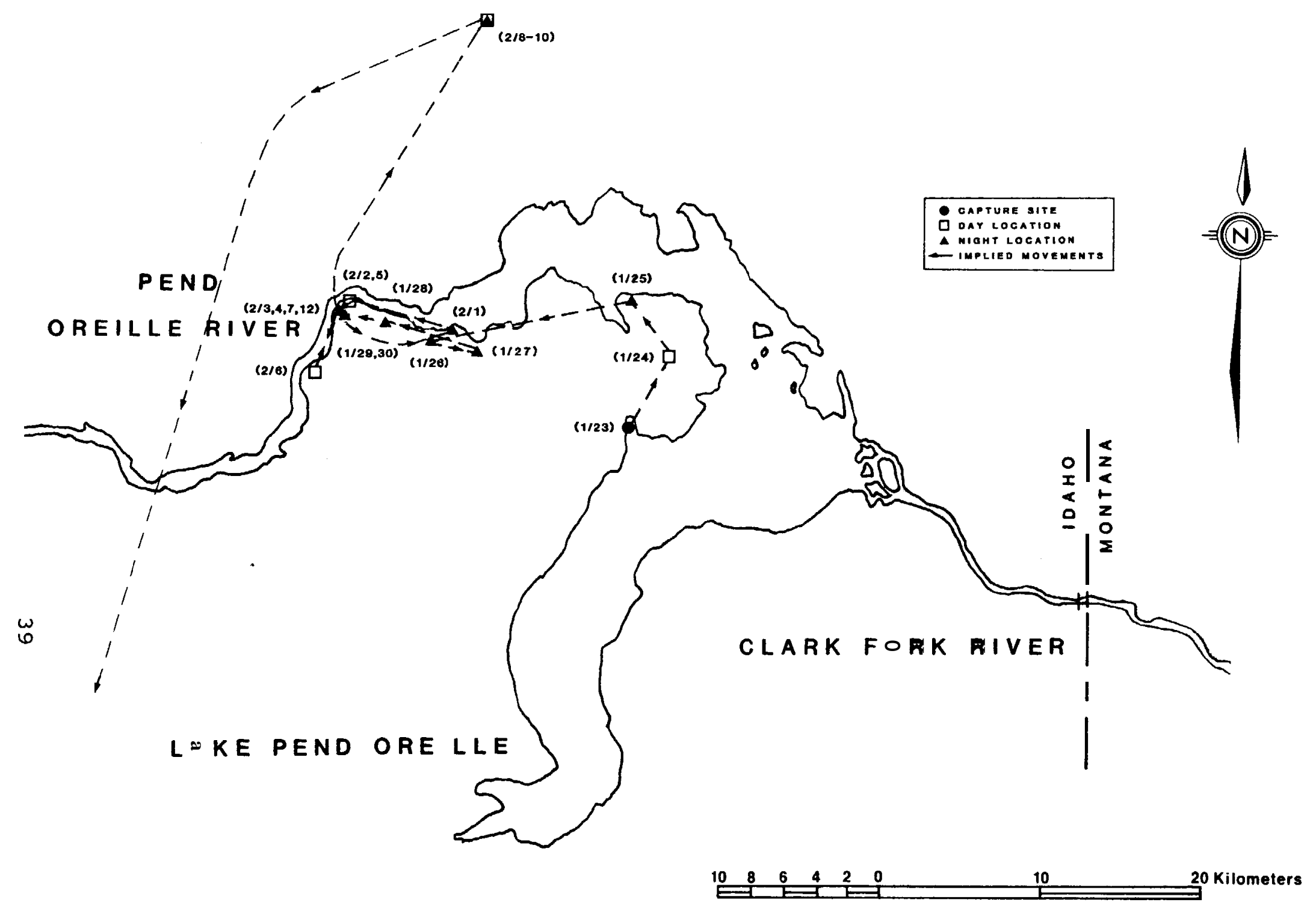

Figure 22. Movements of bald eagle \#01, 1985-86. 


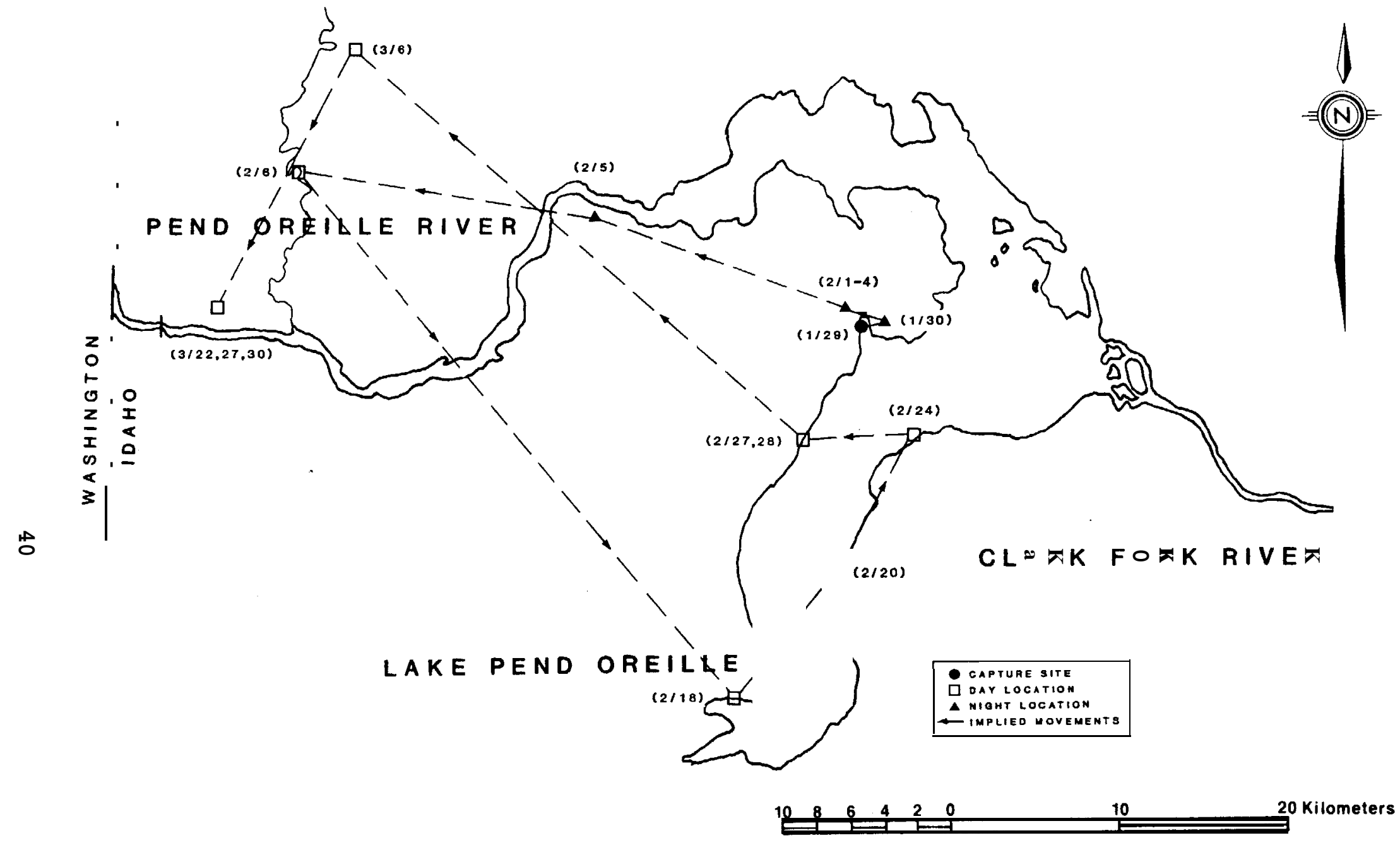

Figure 23. Movements of bald eagle \#02, 1985-86. 
following day to the Priest River where it was observed feeding on fish. Eagle \#02 could not be located again until 18 February when it was found at the southern end of lake Pend Oreille. It departed the southern half of the lake on 4 March and was observed on 6 March near the Priest River with an adult and a subadult bald eagle and several ravens (Corvus corax) feeding on a cow (Bovidae spp.) carcass. It was once again out of telemetry contact until 22 March when it was observed feeding on the carcass of a whitetail deer (Odocoileus virainianus) $3 \mathrm{~km}$ north of the Pend Oreille River. The eagle was located in the same area on two more occasions until departing the area after 30 March.

Eaqle \#03

Another adult eagle, \#03, was captured at $1026 \mathrm{~h}$ on 8 February 1986 near the east shoreline of Garfield Bay (Fig. 24). It roosted the next two nights near the bay, but flew north on 10 February to roost west of Bottle Bay. Eagle \#03 moved west to remain along the Pend Oreille River for the next four days, after which time it flew back to the lake near Garfield Bay. It was sighted far to the southeast on Cabinet Gorge Reservoir on 20 February, moved back downstream along the Clark Fork River during the next three days, and was last sighted during the winter of 1985-86 on 25 February flying to roost from Denton Slough on Lake Pend Oreille.

Eagle \#03 returned to the lake on 9 November 1986 and roosted near the Clark Fork River delta (Fig. 25). It roosted to the north near Denton slough the following evening and returned again to the delta one day later. On 12 November, it flew west to the Pend Oreille River south of Smith Creek where it remained for the next 2 weeks, until moving back to the lake $8 \mathrm{~km}$ south of Garfield Bay on 26 November. Eagle \#03 was sighted next back at Denton Slough: it roosted and hunted in the vicinity until flying to Lightning Creek along the Clark Fork River on 2 December. It was observed the next ten days hunting and feeding on kokanee salmon on the creek and the river, and then flew to Granite Creek Bay on the lake. After two days, it moved to the southern end of the lake, remaining there from 15-18 December; approximately 150 eagles were in this area at this time feeding on salmon spawning along the shoreline and at the mouth of tributaries. On 31 December, eagle \#03 was back at Denton Slough, then moved northwest near the Pack River delta, and finally back to the Clark Fork delta in early January. It remained in the vicinity of Denton Slough from 7-12 January.

Signals from eagle \#03's transmitter were not received again for over two weeks from either ground or aerial monitoring. On 29 January, eagle \#03 was sighted back at 


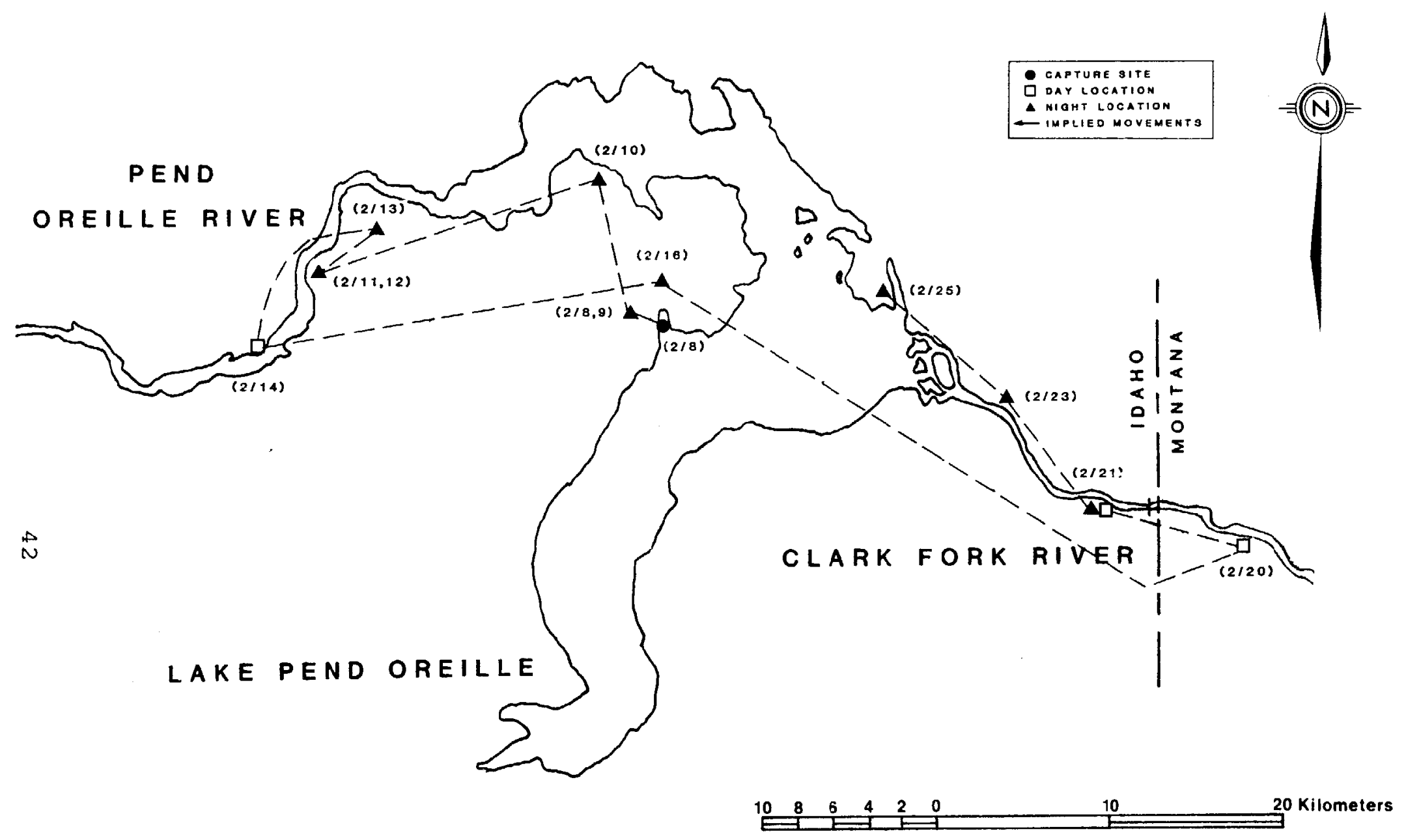

Figure 24. Movements of bald eagle \#03, 1985-86. 


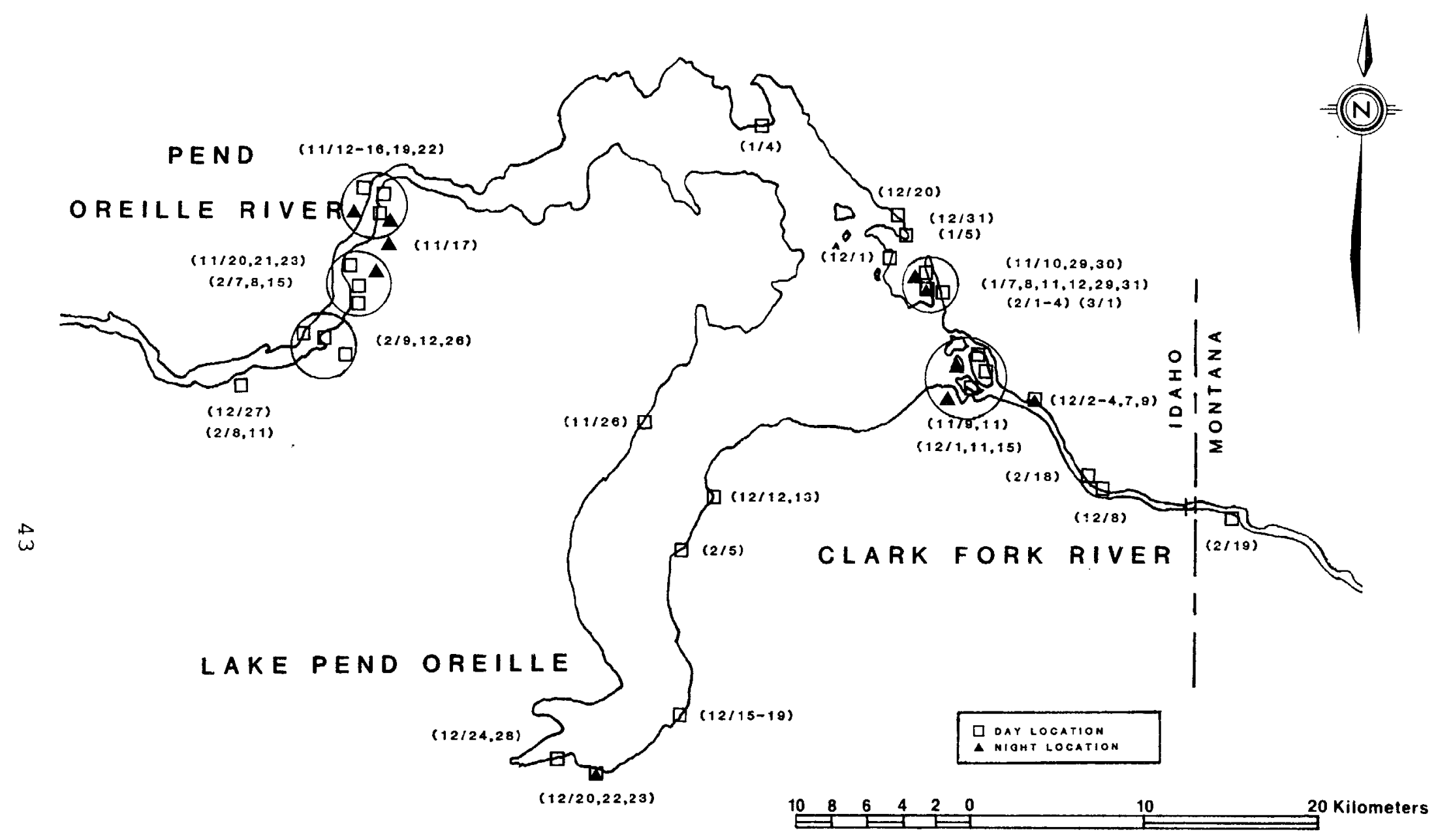

Figure 25. Movements of bald eagle \#03, 1986-87. 
Denton slough during the weekly aerial census, and remained at this location for the next week. At Denton Slough, extensive shallows exist and, when warmer temperatures begin to melt the ice cover, live and dead winter-killed fish become more available. Eagle \#03 left the slough for the southern part of the lake on 5 February, continued west stopping along the Pend Oreille River where it remained from 7-15 February. It returned to Denton Slough to roost the evening of 15 February, flew about $7 \mathrm{~km}$ up the Clark Fork River on 18 February, and flew above the Cabinet Gorge Dam about $14 \mathrm{~km}$ further upstream on the following day. It returned to the Pend Oreille River from 20-28 February and then flew to the Clark Fork River delta/Denton Slough area. Eagle \#03 was once again out of telemetry contact for the first week of March. However, it was subsequently located along the Kootenai River near Troy, Montana, $14 \mathrm{~km}$ east of the Idaho border, approximately $45 \mathrm{~km}$ from its last location on Lake Pend Oreille. It was sighted on numerous days from early March until its departure in mid-April.

Eagle \#04

An adult bald eagle, \#04, was captured in Garfield Bay at $1012 \mathrm{~h}$ on 17 February 1986. After release, it flew to perch in a ponderosa pine (Pinus ponderosa) approximately $1 \mathrm{~km}$ west of the bay. No additional signals were received from eagle \#04's transmitter later that evening or during subsequent monitoring sessions.

Eagle \#05

Eagle \#05, an adult, was captured at $0916 \mathrm{~h}$ on 19 February 1986 at Garfield Bay (Fig. 26). The eagle remained in the northern part of Lake Pend Oreille until 23 February when it flew south out of telemetry contact. From 10-20 March, \#05 was observed perched in a grove of cottonwoods (Populus spp.), and with other eagles and ravens feeding on a whitetail deer carcass along the St. Joe River near Calder, Idaho, approximately $110 \mathrm{~km}$ south of its last known location on Lake Pend Oreille.

On 24 December 1986, eagle \#05 was once again sighted in northern Idaho along the Pend Oreille River where it remained for the next three days. On 29 December, it moved onto northern Lake Pend Oreille near the Pack River Delta until 5 January when it flew to the Clark Fork River delta area. By 8 January, \#05 moved to Granite Creek where it was observed feeding on spawning kokanee salmon with several other eagles. It remained in this area until 20 January when the signal from its transmitter could no longer be received. 


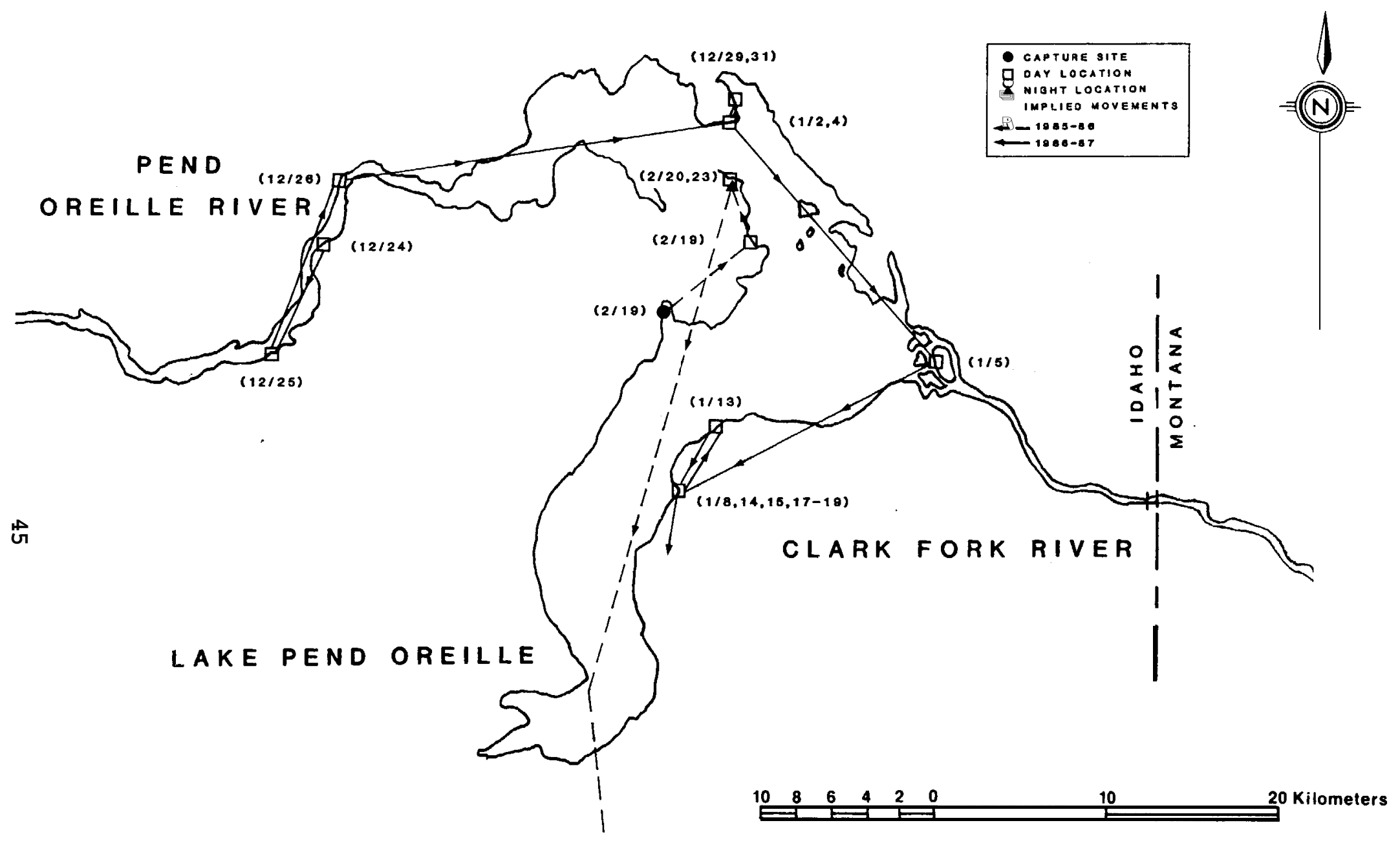

Figure 26. Movements of bald eagle \#05, 1985-86 and 1986-87. 
Eagle \#06

Subadult eagle \#06 was captured at $1045 \mathrm{~h}$ on 24 February 1986 along the west side of Garfield Bay (Fig. 27). It was located the following day to the northeast near the Pack River delta. It then moved to the Clark Fork River delta on 26 February and roosted in the Johnson Creek area. On 27 February, it was observed feeding on a whitetail deer carcass on the shore of the Clark Fork River and was located on subsequent days in this area through 8 March. By 12 March, eagle \#06 had moved upstream along the river to the confluence with the Bull River, Montana, and then moved another $10 \mathrm{~km}$ onto Noxon Reservoir the next day where it was sighted perched on ice along the edge of open water above Noxon Rapids Dam. Five days later on 18 March, eagle \#06 was back on Lake Pend Oreille along Denton Slough where it remained until leaving the study area in mid-afternoon on 22 March.

Eagle \#06, in adult plumage, returned to Lake Pend Oreille along Denton Slough on 29 January 1987 (Fig. 28). Subsequent locations documented movements on the Clark Fork River and delta, and then back to Denton slough on 18 February. On 23 February, eagle \#06 moved approximately $70 \mathrm{~km}$ downstream along the Pend Oreille River to Indian Island, Washington. Five days later, the eagle had returned to Denton slough where it remained feeding on fish for the next 23 days until it departed the area on 22 March.

\section{Eaqle \#07}

Adult bald eagle \#07 was captured at $0917 \mathrm{~h}$ on 11 March 1986 offshore from Pearl Island (Fig. 29). It departed the lake about $1200 \mathrm{~h}$ two days later, flying approximately $25 \mathrm{~km}$ north into the Cabinet Mountains, where it resided at approximately $1200 \mathrm{~m}$ elevation for the next six days. The final telemetry signal from \#07 was received at $0900 \mathrm{~h}$ on 19 March in the same area; no signal was received by $1400 \mathrm{~h}$.

Eagle \#08

Eagle \#08, a subadult, was captured at $0837 \mathrm{~h}$ on 4 April 1986 north of Sunrise Bay and roosted that evening near the capture site (Fig. 30). It flew northwest out of the study area the following day: its transmitter signal was lost by early afternoon.

The first location of-eagle \#08 in 1987 was along the Pend Oreille River on 8 February. Two days later, the eagle had moved east about $45 \mathrm{~km}$ to Lake Pend Oreille near the capture site of the previous year. By 15 February, it was sighted once again along the Pend Oreille River, this time just across the Washington/Idaho border. Eagle \#08 could not be located for about three weeks until mid-March when it 


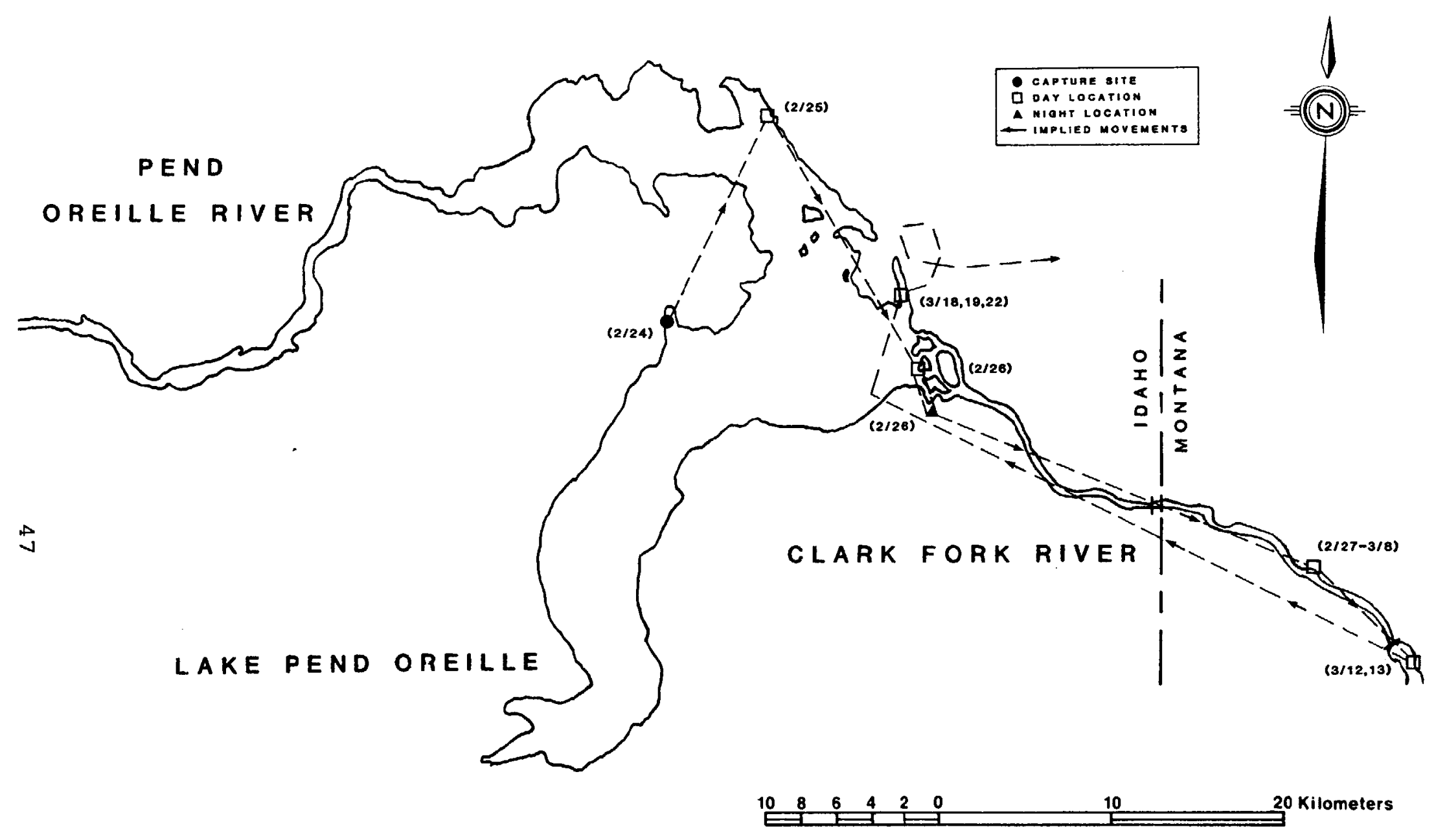

Figure 27. Movements of bald eagle \#06, 1985-86. 


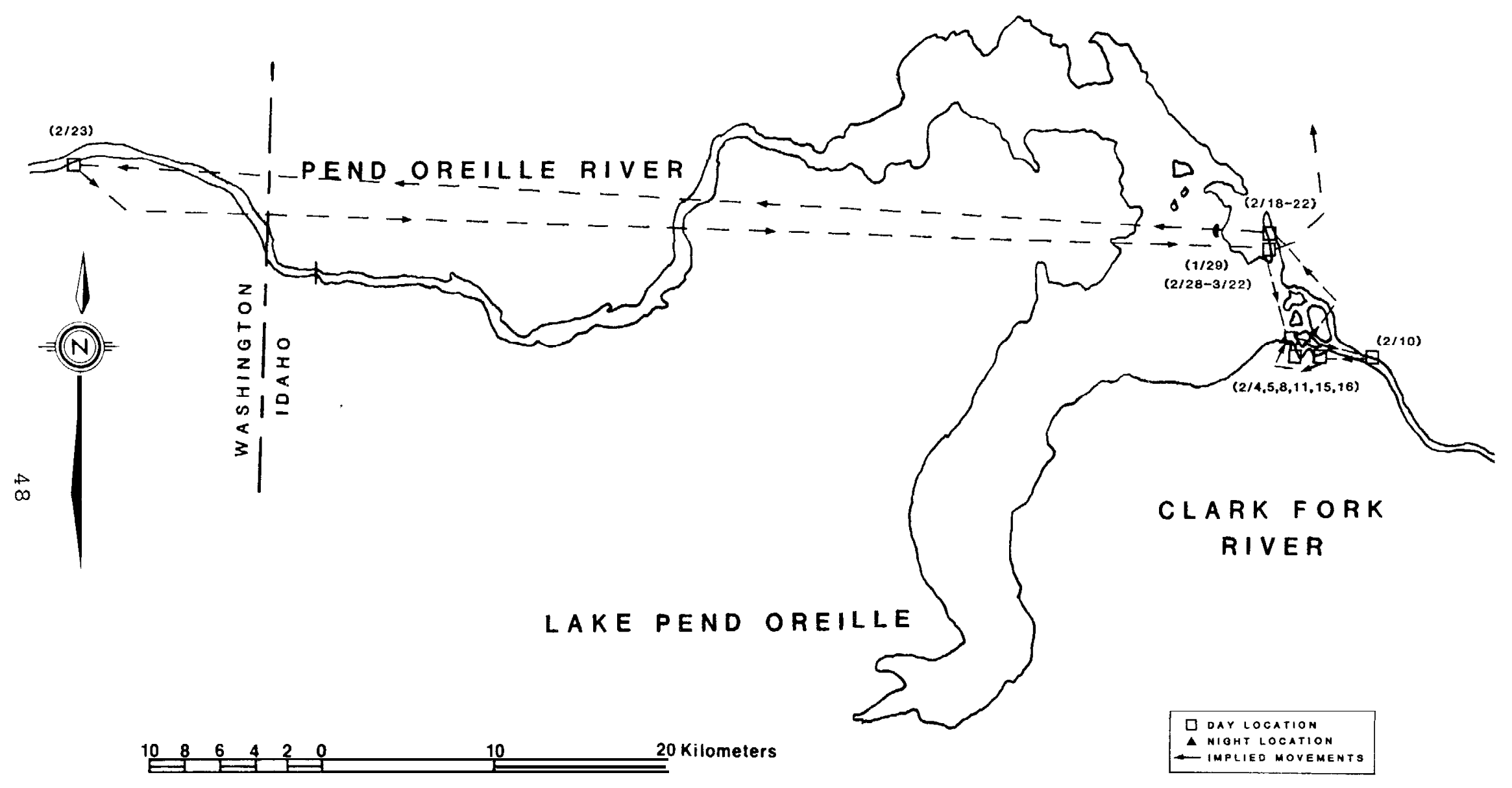

Figure 28. Movements of bald eagle \#06, 1986-87. 


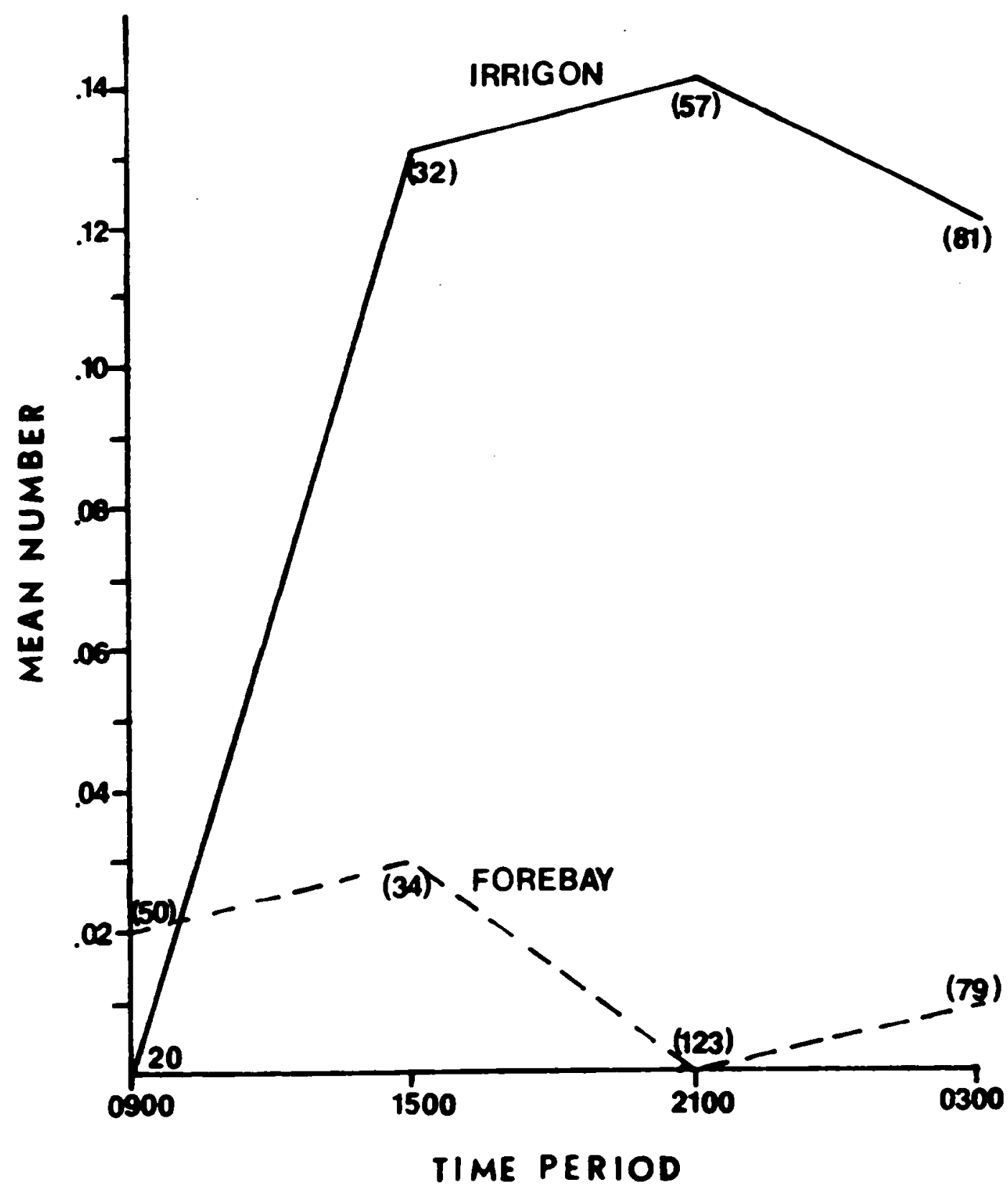

Figure 13. Mean number of juvenile salmonids consumed and time of capture for smallmouth bass collected at Irrigon and the John Day forebay, April to September 1982. Time periods are midpoints of six hour intervals. Sample sizes are in parentheses. 


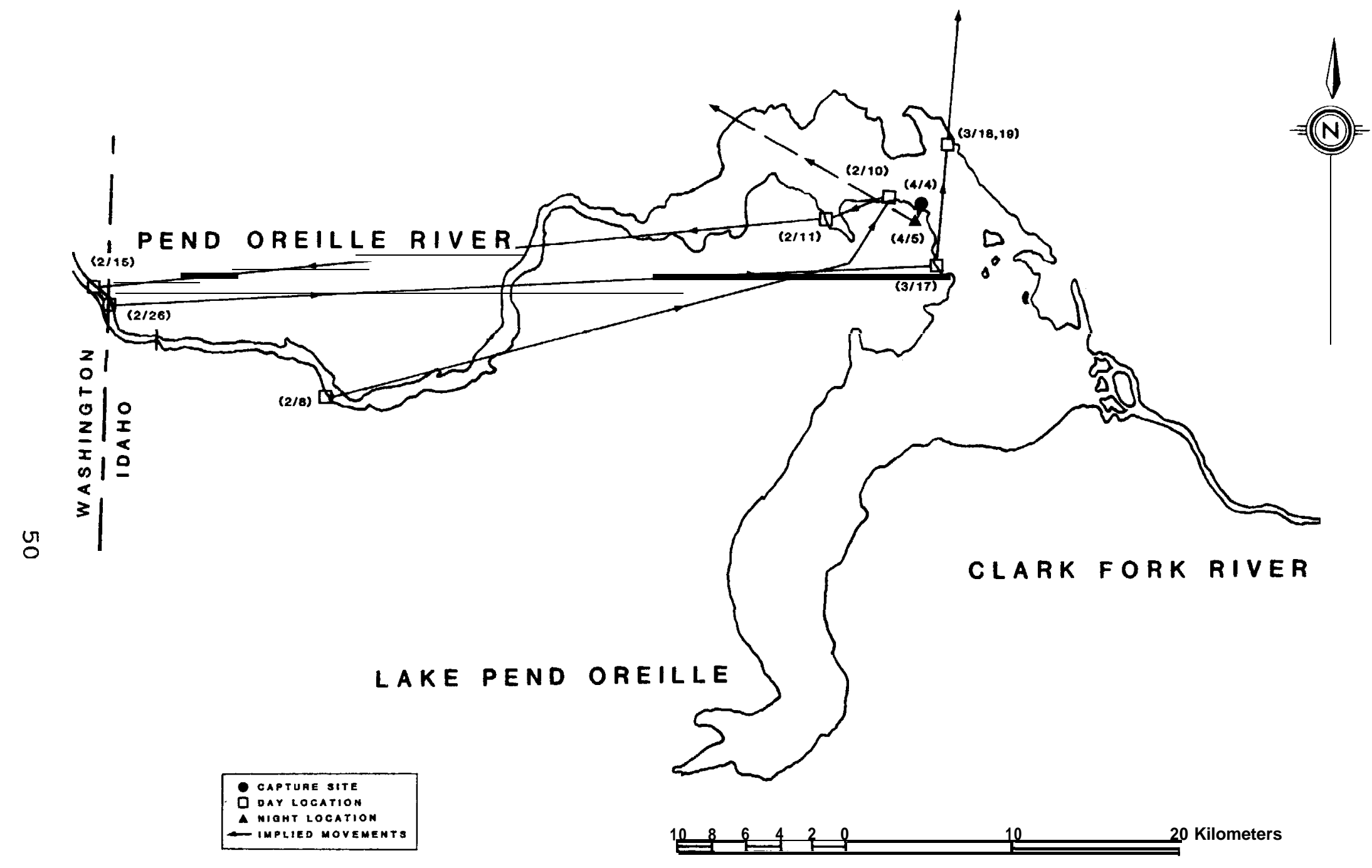

Figure 30. Movements of bald eagle \#08, 1985-86 and 1986-87. 
was observed on Lake Pend Oreille south of Sunrise Bay. It then spent two days along the Pack River delta before flying north out of the area on 19 March.

Interchange of Easles With McDonald Creek Concentration During the autumn of 1986, Glacier National Park, Montana, personnel at the McDonald Creek eagle concentration monitored for Lake Pend Oreille transmitter-equipped bald eagles. No transmitter signals were received nor were any green wing-markers observed during the concentration period (Oct.-Dec.).

Bald eagles equipped with wing-markers in Glacier National Park since 1977 (N > 100) were watched for during both years of the study on Lake Pend Oreille. Only one wing-marked eagle (A23) from the park was observed in the study area. The eagle was sighted along the south shore of the Pend Oreille River opposite Sandpoint on 27 January 1986, and approximately $16 \mathrm{~km}$ further downstream on 28 January: it was not seen in 1986-87. Eagle A23 was originally captured in the park as a juvenile on 18 November 1978 and has not been observed there during subsequent autumns: however, it was observed at Modoc National Wildlife Refuge in northeastern California on 15 January 1985 (McClelland, personal communication, 1985).

Known long-range movements of transmitter-equipped eagles at Lake Pend Oreille and Glacier National Park (Young 1983, McClelland et al. 1984, B. R. McClelland, personal communication, 1987) indicate little exchange of eagles migrating between the two locations. However, with the apparent collapse of the eagle concentration in the park in the autumn of 1987 resulting from extremely low salmon numbers (B. R. McClelland, personal communication, 1987), the possibility of a future increase in the number of eagles migrating into the lake Pend Oreille area from the east seems more likely, particularly if alternative prey resources are not available.

\section{NOCTURNAL ROOSTS}

At night, wintering bald eagles have been observed roosting singly, in small groups, or communally in locations to which they may return on a regular basis (Shea 1973, Steenhof et al. 1980, Keister and. Anthony 1983). In the Lake Pend Oreille area, many instance's of roosting by small numbers of eagles were documented and three major roosts were identified (Fig. 31). Fewer roost locations were obtained in southern Lake Pend Oreille due to its inaccessibility by automobile throughout most of the winter months. Two nocturnal roosts along the Pend Oreille River 


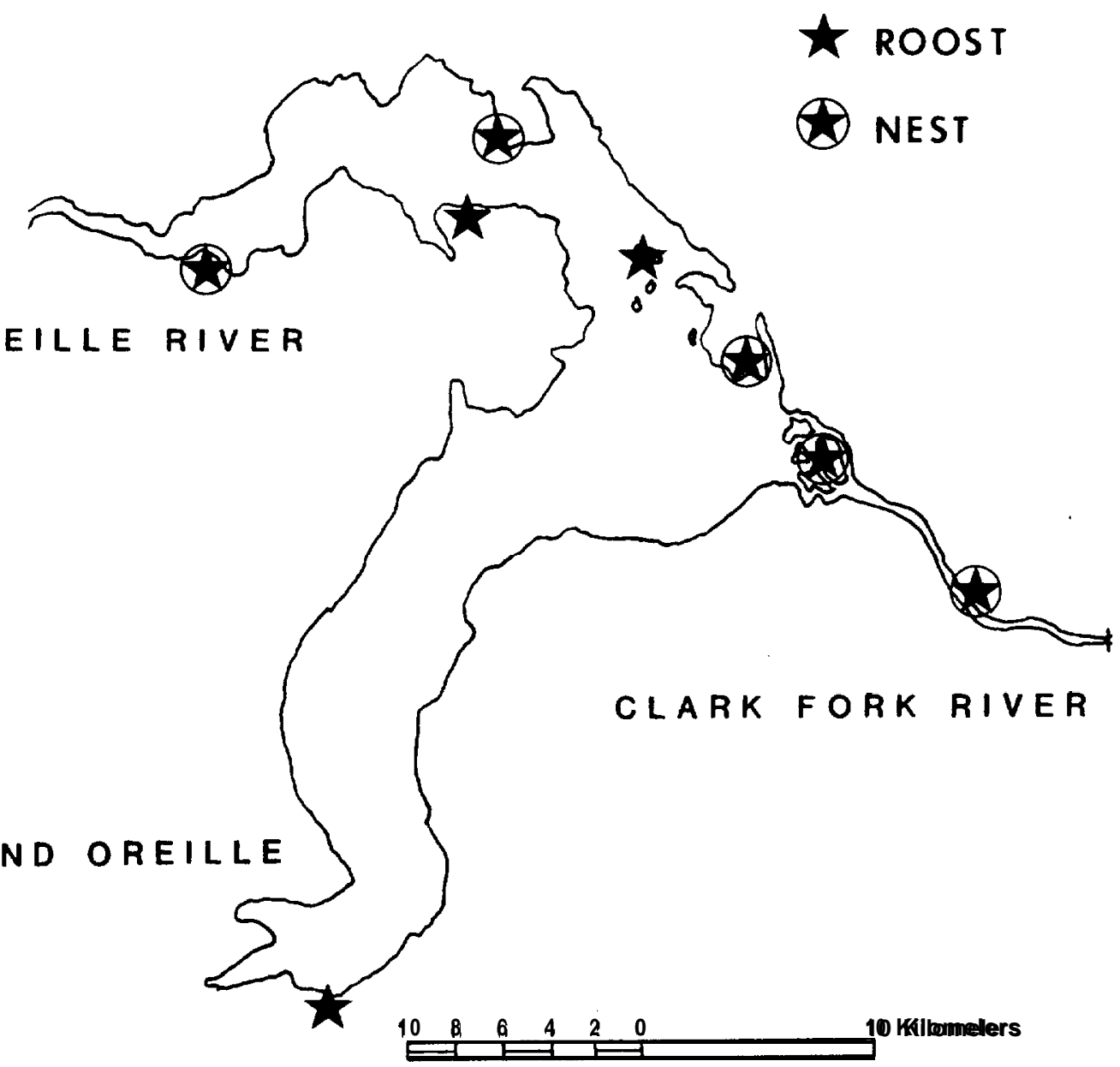

Figure 31. Map of major nocturnal roosts of bald eagles on Lake Pend Oreille and bald eaqle nests, 1985-86 and 1986-87. 
identified by Meyer (1979) were used sporadically in 1985-86 and 1986-87 by relatively few eagles as were numerous other sites. The use of numerous roost sites dispersed throughout the study area may indicate the importance of eagles remaining near a plentiful, but shifting food source, and no lack of suitable roost trees.

Warren Island Roost

Warren Island Roost lies along a north-south ridgeline on the western side of this privately-owned island at a mean elevation of $2140 \mathrm{~m}$ and mean distance to the lake of approximately $122 \mathrm{~m}$ (SW 1/4, Sec. 34, T57N, R1E; NW 1/4, Sec. 3, T56N, R1E, Boise Meridian) (Appendix D-1). Several homesites exist at scattered locations near the shoreline of the island, but none are in use during the winter months when eagle use occurs.

Counts of eagles at the roost from early December to March revealed frequent use and high numbers of eagles present (maximum count: 49 [1985-86]; 32 [1986-87]), particularly during 1985-86 when more eagles remained in the northern parts of the lake (Tables 5 and 6 ).

Eight roost trees were identified during counts and reaffirmed by collection of pellets and prey remains at the tree bases (Table 7). Mean tree dbh was $61.9 \mathrm{~cm}$; mean tree height was $29.4 \mathrm{~m}$. Douglas-fir (Pseudotsusa menzeisii) and western larch (Larix occidentalis) were the most common roost tree species. Five of the roost trees were snags; two of these were blown down by high winds in the summer of 1987 .

\section{East Bottle Bay Roost}

East Bottle Bay Roost lies on a north-facing slope on private and USFS land from approximately $215 \mathrm{~m}$ from the lakeshore at $2200 \mathrm{~m}$, up-slope to just below the summit of a ridge at $2900 \mathrm{~m}$ (SW 1/4, SE 1/4, Sec. 27, and $\mathrm{NE} \mathrm{1/4,}$ Sec. 34, T57N, R1W, Boise Meridian) (Appendix D-2). A dirt road accesses summer homesites near the roost from its lower end, but is seldom-used during winter. Old, partially overgrown logging roads traverse the roost.

Bald eagles roosted at East Bottle Bay throughout the concentration periods of both years (Table 8); the peak count occurred in late November (46 eagles). Large fluctuations in roost count totals during periods of heavy use may be due to thermal conditions promoting soaring activity by eagles on count days; in several instances, groups of eagles were observed leaving nearby feeding locations at Bottle Bay, then flying beyond and above the roost at dark to land at other locations higher on the hillside. High numbers of eagles of unidentified age class 
Table 5. Counts of bald eagles at Warren Island Roost, 1985-86.

Date Time Adults Subadults Unidentified Total

\begin{tabular}{|c|c|c|c|c|c|c|}
\hline 3 & Dec. & PM & 15 & 19 & 3 & 37 \\
\hline 4 & Dec. & $\mathrm{PM}$ & 0 & 0 & 42 & 42 \\
\hline 5 & Dec. & PM & 0 & 0 & 35 & 35 \\
\hline 6 & Dec. & $\mathrm{AM}$ & 0 & 0 & 27 & 27 \\
\hline 7 & Dec. & $\mathbf{A M}$ & 0 & 0 & 23 & 23 \\
\hline 8 & Dec. & PM & 27 & 10 & 0 & 37 \\
\hline 9 & Dec. & $\mathrm{PM}$ & 0 & 0 & 49 & 49 \\
\hline 11 & Dec. & PM & 0 & 0 & 43 & 43 \\
\hline 13 & Dec. & PM & 0 & 0 & 39 & 39 \\
\hline 14 & Dec. & PM & 0 & 0 & 33 & 33 \\
\hline 15 & Dec. & PM & 0 & 0 & 30 & 30 \\
\hline 16 & Dec. & PM & 0 & 0 & 34 & 34 \\
\hline 17 & Dec. & PM & 0 & 0 & 24 & 24 \\
\hline 18 & Dec. & $\mathbf{A M}$ & 0 & 0 & 27 & 27 \\
\hline 20 & Dec. & PM & 0 & 0 & 24 & 24 \\
\hline 24 & Dec. & PM & 0 & 0 & 8 & 8 \\
\hline 25 & Dec. & PM & 5 & 6 & 0 & 11 \\
\hline 17 & Jan. & PM & 17 & 6 & 0 & 23 \\
\hline 21 & Jan. & PM & 10 & 3 & 0 & 13 \\
\hline 24 & Jan. & PM & 8 & 7 & 0 & 15 \\
\hline 26 & Jan. & PM & 3 & 0 & 8 & 11 \\
\hline 28 & Jan. & PM & 6 & 10 & 0 & 16 \\
\hline 31 & Jan. & PM & 9 & 7 & 7 & 23 \\
\hline 6 & Feb. & PM & 2 & 5 & 0 & 7 \\
\hline 7 & Feb. & PM & 4 & 2 & 2 & 8 \\
\hline 11 & Feb. & PM & 5 & 2 & 0 & 7 \\
\hline 14 & Feb. & PM & 6 & 2 & 0 & 8 \\
\hline 18 & Feb. & PM & 1 & 0 & 0 & 1 \\
\hline 21 & Feb. & PM & 2 & 1 & 0 & 3 \\
\hline 25 & Feb. & PM & 3 & 3 & 0 & 6 \\
\hline 28 & Feb. & PM & 2 & 3 & 0 & 5 \\
\hline 4 & Mar: & PM & 1 & 1 & 0 & 2 \\
\hline 8 & Mar. & PM & 0 & 0 & 0 & 0 \\
\hline
\end{tabular}


Table 6. Counts of bald eagles at Warren Island Roost, 1986-87.

Date Time Adults Subadults Unidentified Total

\begin{tabular}{|c|c|c|c|c|c|c|}
\hline 9 & Dec. & PM & 0 & 0 & 10 & 10 \\
\hline 11 & Dec. & $\mathrm{PM}$ & 5 & 8 & 3 & 16 \\
\hline 18 & Dec. & PM & 8 & 13 & 11 & 32 \\
\hline 6 & Jan. & PM & 6 & 7 & 7 & 20 \\
\hline 13 & Jan. & PM & 1 & 1 & 0 & 2 \\
\hline 19 & Jan. & $\mathrm{PM}$ & 8 & 8 & 0 & 16 \\
\hline 22 & Jan. & PM & 3 & 8 & 2 & 13 \\
\hline 26 & Jan. & PM & 3 & 0 & 8 & 11 \\
\hline 29 & Jan. & PM & 3 & 8 & 0 & 11 \\
\hline 18 & Feb. & PM & 1 & 4 & 0 & 5 \\
\hline 5 & Mar. & PM & 1 & 0 & 0 & 1 \\
\hline
\end{tabular}


Table 7. Characteristics of eight roost trees at Warren Island Roost, 1987.

\begin{tabular}{|c|c|c|c|c|c|c|}
\hline $\begin{array}{c}\text { Tree } \\
\text { no. }\end{array}$ & Aspect & $\begin{array}{c}\text { Slope } \\
\text { (degrees) }\end{array}$ & $\begin{array}{l}\text { Tree } \\
\text { dbh } \\
(\mathrm{cm})\end{array}$ & $\begin{array}{l}\text { Tree } \\
\text { height } \\
\text { (m) }\end{array}$ & $\begin{array}{l}\text { Tree } \\
\text { species }\end{array}$ & $\begin{array}{c}\text { Tree } \\
\text { condition }\end{array}$ \\
\hline 1 & $s-s w$ & 10 & 105.5 & 44.9 & $\begin{array}{c}\text { Douglas- } \\
\text { fir }\end{array}$ & Snag \\
\hline 2 & $\dot{s}$ & 6 & 67.0 & 31.5 & $\begin{array}{c}\text { Douglas- } \\
\text { fir }\end{array}$ & $\begin{array}{l}\text { Live: } \\
\text { full crown }\end{array}$ \\
\hline 3 & $\mathrm{E}-\mathrm{NE}$ & 5 & 38.8 & 25.2 & $\begin{array}{l}\text { Western } \\
\text { larch }\end{array}$ & Snag \\
\hline 4 & $\mathbf{S}-\mathbf{S W}$ & 2 & 39.6 & 24.1 & $\begin{array}{c}\text { Douglas- } \\
\text { fir }\end{array}$ & Snag \\
\hline 5 & S-SW & 8 & 49.0 & 28.0 & $\begin{array}{l}\text { Western } \\
\text { larch }\end{array}$ & $\begin{array}{l}\text { Snag; } \\
\text { down }\end{array}$ \\
\hline 6 & $\mathrm{~N}-\mathrm{NE}$ & 4 & 42.4 & 24.0 & $\begin{array}{c}\text { Western } \\
\text { larch }\end{array}$ & $\begin{array}{l}\text { Snag; } \\
\text { down }\end{array}$ \\
\hline 7 & S-SW & 1 & 81.9 & 38.0 & $\begin{array}{c}\text { Black } \\
\text { Cottonwood }\end{array}$ & $\begin{array}{c}\text { Live: } \\
1 / 2 \text { crown }\end{array}$ \\
\hline 8 & $\mathbf{W}$ & 1 & 70.6 & 19.1 & $\begin{array}{c}\text { Douglas- } \\
\text { fir }\end{array}$ & $\begin{array}{c}\text { Live: } \\
\text { broken top; } \\
\text { osprey nest }\end{array}$ \\
\hline
\end{tabular}


Table 8. Counts of bald eagles at East Bottle Bay Roost, 1985-86 and 1986-87.

Date Time Adults Subadults Unidentified Total

\section{$\underline{1985-86}$}

19 Nov. PM

24 Nov. PM

26 Nov. AM

26 Nov. PM

30 Nov. PM

8 Dec. PM

26 Dec. PM

14 Jan: PM

17 Feb. PM

26 Mar. PM

0
0
0
2
22
1
1
2
11
15
0

10

13

46

6

2

$\begin{array}{ll}5 & 6 \\ 0 & 1\end{array}$

$17 \quad 20$

$0 \quad 13$

$\begin{array}{rr}4 & 23 \\ 0 & 0\end{array}$

1986-87

$\begin{array}{rlrrrrr}10 & \text { Dec. } & \text { PM } & 12 & 12 & 0 & 24 \\ 23 & \text { Dec. } & \text { PM } & 3 & 0 & 0 & 3 \\ 4 & \text { Feb. } & \text { PM } & 2 & 2 & 0 & 4\end{array}$


and some of the variability in roost count totals resulted from the extreme distances from observers to the roost, and the presence of weather conditions (sun glare, fog, low clouds, precipitation) preventing more accurate results. Total counts of roosting eagles at this and other roosts were believed to be conservative due to these factors and the inability to observe all roost trees from count locations.

Use of ten roost trees at East Bottle Bay was identified visually and confirmed later by the presence of numerous pellets and prey remains at the bases of the trees (Table 9). Four trees were measured: mean dbh was $65.5 \mathrm{~cm}$; mean height was $41.8 \mathrm{~m}$. All of these trees were dead western larch. Eagles at this roost probably also use live trees, but due to the break-up and scattering of pellets as they fall and hit branches, and the difficulty in locating them from the ground, these trees were not adequately represented in the sample of trees measured.

Echo Bay Roost

Echo Bay Roost lies at the south end of Lake Pend Oreille on a north-facing slope of USFS land at a mean elevation of $2400 \mathrm{~m}$ and a mean distance to the lake of $120 \mathrm{~m}$ (NE 1/4, Sec. 13, T53N, R2W, Boise Meridian) (Appendix D-3). No development has occurred near the roost; though it is exposed to disturbance by boat traffic on the lake, minimal human activity occurs during winter.

The inaccessibility of the roost and inclement weather conditions which often prevailed in this area in winter prevented systematic counts of roosting eagles. On 23 December 1986, 33 bald eagles ( 30 adults, 3 subadults) were counted in the roost; this count was coincident with peak eagle numbers in the study area in 1986-87 and with peak counts of eagles in the southern part of the lake feeding on kokanee salmon.

\section{BALD EAGLE NESTS}

Three active bald eagle nests within the study area had been identified prior to this study; two additional nests were located in the winter of 1985-86 (Fig. 31). Incubation by adults began in late February or March both years at the four active nests (Table 10). A mean of one fledgling/nest at known productive sites was produced in 1986; a mean of 1.6 fledglings/nest was produced in 1987. The nesting pair of eagles at the Colby site apparently established an alternate nest site in 1987 and may have also used the same site in 1986; the new nest location has not been determined. 
Table 9. Characteristics of four roost trees at warren Island Roost, 1987 .

\begin{tabular}{|c|c|c|c|c|c|c|}
\hline $\begin{array}{c}\text { Tree } \\
\text { no. }\end{array}$ & Aspect & $\begin{array}{c}\text { Slope } \\
\text { (degrees) }\end{array}$ & $\begin{array}{l}\text { Tree } \\
\text { dbh } \\
(\mathrm{cm})\end{array}$ & $\begin{array}{l}\text { Tree } \\
\text { height } \\
\text { (m) }\end{array}$ & $\begin{array}{l}\text { Tree } \\
\text { species }\end{array}$ & $\begin{array}{l}\text { Tree } \\
\text { condition }\end{array}$ \\
\hline 1 & $\mathrm{~N}-\mathrm{NE}$ & 27 & 69.5 & 42.6 & $\begin{array}{c}\text { Western } \\
\text { larch }\end{array}$ & Snag \\
\hline 2 & $\mathrm{~N}$ & 29 & 63.5 & 38.9 & $\begin{array}{l}\text { Western } \\
\text { larch }\end{array}$ & Snag \\
\hline$\exists$ & $\mathrm{N}$ & 30 & 66.1 & 39.0 & $\begin{array}{l}\text { Western } \\
\text { larch }\end{array}$ & Snag \\
\hline 4 & $\mathrm{~N}$ & 34 & 64.0 & 46.8 & $\begin{array}{c}\text { Western } \\
\text { larch }\end{array}$ & $\begin{array}{l}\text { Snag: } \\
\text { broken top }\end{array}$ \\
\hline
\end{tabular}


Table 10. Bald eagle incubation dates, nest productivity, and land ownership on Lake Pend Oreille, the lower Clark Fork River, and the upper Pend oreille River, 1986 and 1987.

\begin{tabular}{|c|c|c|c|c|c|}
\hline \multirow{2}{*}{$\begin{array}{l}\text { Nest } \\
\text { location }\end{array}$} & \multicolumn{2}{|c|}{$\begin{array}{c}\text { Date incubation } \\
\text { initiated }\end{array}$} & \multicolumn{2}{|c|}{$\begin{array}{l}\text { No. young } \\
\text { fledged }\end{array}$} & \multirow{2}{*}{$\begin{array}{l}\text { Land } \\
\text { ownership }\end{array}$} \\
\hline & 1986 & 1987 & 1986 & 1987 & \\
\hline $\begin{array}{l}\text { Fisherman } \\
\text { Island }\end{array}$ & 22 Mar. & 20 Mar. & 2 & 2 & Federal \\
\hline $\begin{array}{l}\text { Sheepherder } \\
\text { Point }\end{array}$ & 27 Feb. & 5 Mar. & unknown & 1 & Private \\
\hline $\begin{array}{l}\text { Clark Fork } \\
\text { River Delta }\end{array}$ & 6 Mar. & 5 Mar. & 1 & 1 & Private \\
\hline Colby & inactive & inactive & 0 & $0^{*}$ & Private \\
\hline $\begin{array}{l}\text { Springy } \\
\text { Point }\end{array}$ & 22 Mar. & 12 Mar. & 0 & 2 & Private \\
\hline
\end{tabular}

* Two young fledged at alternate nest. 
Lake Pend Oreille

The most common habitat types within the 21 units of the shoreline zone $(100 \mathrm{~m}$ width) on Lake Pend Oreille were western redcedar (Thuja plicata)/queencup beadlily (Clintonia uniflora) and Douglas-fir/ninebark (Physocarpus malvaceus) (Table 11). A mean of $44 \%$ of each unit was unforested: a mean of $17 \%$ was forested with old-growth and $34 \%$ with mature trees. Mean height of upper canopy trees was $23.2 \mathrm{~m}$; mean density was 3.1 trees/ha. The northern half of the lake (units 11-12, 15-23) had gentler terrain and fewer steep slopes than the southern half of the lake (units 1-10). A mean of $63.5 \%$ of each northern unit was under private ownership; the USFS owned the majority of each southern unit $(\overline{\mathrm{X}}=98 \%)$ (Fig. 32).

The upland units surrounding the lake were classified into primarily the same habitat types as the shoreline units (Table 12). A smaller percentage of each unit was unforested $(\bar{x}=38 \%)$ : old-growth and mature trees comprised more of each unit $(\bar{x}=45 \%)$. Mean upper canopy tree height $(\bar{x}=22.6 \mathrm{~m})$ and mean density $(\bar{x}=4.7$ trees $/ \mathrm{ha})$ were greater than found near the shoreline. Northern units had a variety of slopes, and were dominated by private ownership $(\bar{x}=84 \%)$. All southern units had some slopes exceeding $60 \%$; most land was owned by the USFS $(\bar{x}=66 \%$ and was managed primarily as natural areas.

\section{Clark Fork River}

The shoreline zone bordering the lower Clark Fork River from the delta upstream to Cabinet Gorge Dam (units 24 and 25) was of the western redcedar/queencup beadlily habitat type. Half of each unit was unforested (50\%); old-growth and mature trees averaged $45 \%$ of each unit. Height of upper canopy trees $(\bar{x}=23.9 \mathrm{~m})$ was similar to lakeshore units: tree density was greater $(\bar{x}=4.1$ trees/ha). Slopes were relatively gentle. Land ownership was private.

In the upland zone, habitat types were similar to those found in the shoreline units. A mean of $50 \%$ of each unit was unforested; a mean of $40 \%$ of each unit was covered with old-growth and mature trees. Upper canopy trees were shorter $(\bar{x}=21.4 \mathrm{~m})$ and of higher densities $(\overline{\mathrm{x}}=8.6$ 'trees/ha) than in adjacent shoreline units. Slopes increased dramatically with elevation. A mean of $80 \%$ of each unit was owned privately.

\section{Pend Oreille River}

The most common habitat type in the shoreline zone along the upper Pend Oreille River (units 13 and 14) was the western redcedar/queencup beadlily type. Unforested areas 
Table 11. Habitat description of Lake Pend oreille shoreline zones (100 m width).

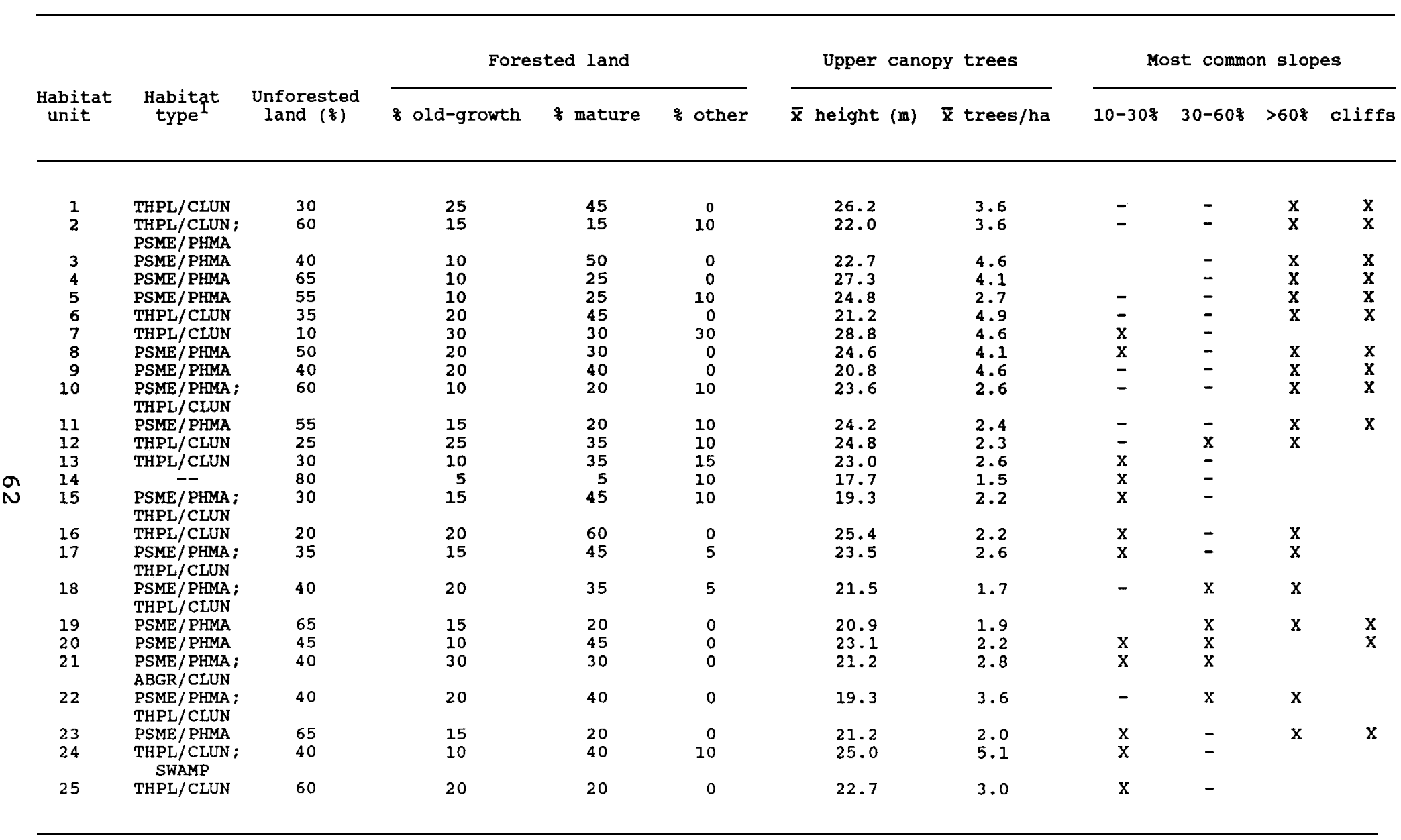

'Habitat type abbreviations: THPL/CLUN: Thuia plicata/Clintonia uniflora (Western redcedar/Queencup beadlily) PSME/PHMA: Pseudotsuqa menzeisii/Physocarpus malvaceus (Douglas-fir/Ninebark) 


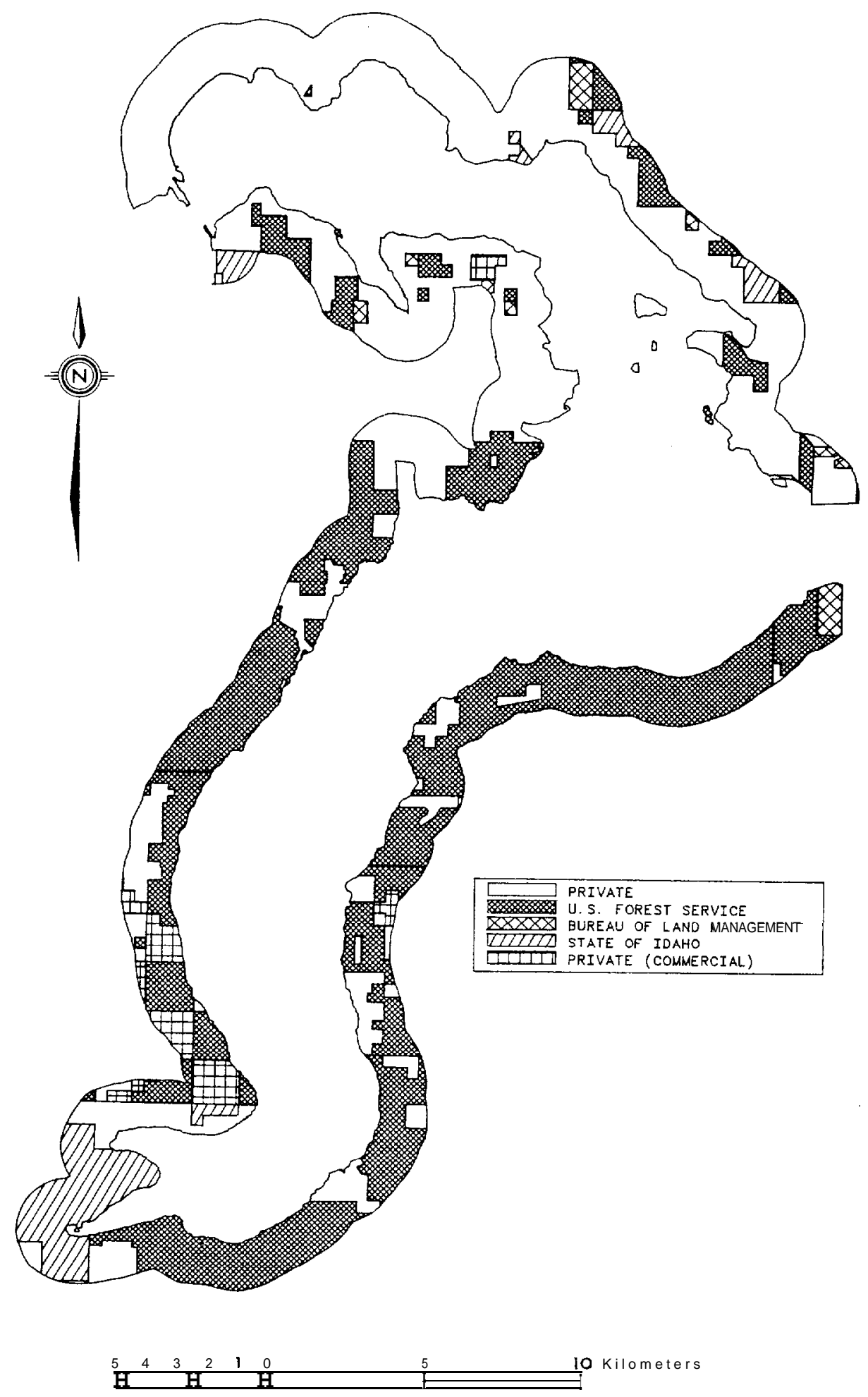

Figure 32. Map of land ownership surrounding Lake Fend Oreille. 
Table 12. Habitat description of Lake Pend Oreille upland zones $(1.6 \mathrm{~km}$ width).

\begin{tabular}{|c|c|c|c|c|c|c|c|c|c|c|c|}
\hline \multirow[b]{2}{*}{$\begin{array}{l}\text { Habitat } \\
\text { unit }\end{array}$} & \multirow{2}{*}{$\begin{array}{l}\text { Habitat } \\
\text { type }\end{array}$} & \multirow{2}{*}{$\begin{array}{l}\text { Unforested } \\
\text { land }(y)\end{array}$} & \multicolumn{3}{|c|}{ Forested land } & \multicolumn{2}{|c|}{ Upper canopy trees } & \multicolumn{4}{|c|}{ Most common slopes } \\
\hline & & & \& old-growth & 8 mature & other & $\overline{\mathrm{x}}$ height (m) & $\bar{x}$ trees/ha & $10-308$ & $30-60 \%$ & $>608$ & cliffs \\
\hline 1 & THPL/CLUN & 15 & 20 & 60 & 5 & 28.0 & 5.1 & & - & $\mathbf{x}$ & $x$ \\
\hline $\mathbf{2}$ & $\begin{array}{l}\text { PSME / PHMA; } \\
\text { THPL/CLUN }\end{array}$ & 40 & 20 & 25 & 15 & 25.7 & 3.3 & - & - & $\bar{x}$ & $x$ \\
\hline 3 & $\begin{array}{l}\text { PSME/ PHMA } \\
\text { THPL/ CLUN }\end{array}$ & 25 & 15 & 40 & 20 & 21.2 & 11.1 & - & $x$ & & $\mathbf{x}$ \\
\hline $\begin{array}{l}4 \\
5\end{array}$ & $\begin{array}{l}\text { THPL/CLUN } \\
\text { THPL/CLUN ; } \\
\text { PSME / PHMA }\end{array}$ & $\begin{array}{l}35 \\
30\end{array}$ & $\begin{array}{r}5 \\
10\end{array}$ & $\begin{array}{l}15 \\
10\end{array}$ & $\begin{array}{l}45 \\
50\end{array}$ & $\begin{array}{l}19.7 \\
15.9\end{array}$ & $\begin{array}{l}8.1 \\
8.5\end{array}$ & $\begin{array}{l}\mathrm{x} \\
\mathrm{x}\end{array}$ & $\bar{x}$ & $\begin{array}{l}\mathbf{x} \\
\mathbf{x}\end{array}$ & $x$ \\
\hline $\begin{array}{l}6 \\
7\end{array}$ & $\begin{array}{l}\text { THPL/CLUN } \\
\text { THPL/CLUN }\end{array}$ & $\begin{array}{l}30 \\
40\end{array}$ & $\begin{array}{l}20 \\
20\end{array}$ & $\begin{array}{l}50 \\
20\end{array}$ & $\begin{array}{r}0 \\
20\end{array}$ & $\begin{array}{l}26.7 \\
29.5\end{array}$ & $\begin{array}{l}5.7 \\
5.6\end{array}$ & $\bar{x}$ & - & $\mathrm{x}$ & $\mathbf{x}$ \\
\hline 8 & PSME / PHMA & 30 & 20 & 40 & 10 & 25.8 & 4.1 & $\hat{x}$ & $\mathrm{x}$ & $\mathrm{x}$ & $\mathbf{x}$ \\
\hline 9 & $\begin{array}{l}\text { PSME / PHMA } \\
\text { ABGR/CLUN }\end{array}$ & 30 & 20 & 40 & 10 & 23.9 & 7.1 & - & - & $\mathbf{x}$ & $x$ \\
\hline 10 & $\begin{array}{l}\text { PSME/PHMA } \\
\text { THPL/CLUN }\end{array}$ & 40 & 10 & 30 & 20 & 24.6 & 7.5 & - & - & $\mathbf{x}$ & $x$ \\
\hline 11 & $\begin{array}{l}\text { THPL/CLUN } \\
\text { PSME/ PHMA }\end{array}$ & 35 & 0 & 20 & 45 & 21.2 & 6.6 & - & - & $\mathbf{x}$ & $x$ \\
\hline 12 & $\begin{array}{l}\text { TSHE/CLUN } \\
\text { THPL/CLUN }\end{array}$ & 35 & 20 & 25 & 20 & 23.1 & 2.0 & $\mathrm{x}$ & - & $\mathrm{x}$ & $\mathbf{x}$ \\
\hline 13 & THPL/CLUN & 60 & 15 & 25 & 20 & 24.5 & 2.6 & $\mathrm{x}$ & - & $\mathrm{x}$ & \\
\hline 14 & $\begin{array}{l}\text { PSME/ PHMA } \\
\text { ABGR/CLUN }\end{array}$ & 65 & 5 & 10 & 25 & 21.2 & 2.1 & $\mathrm{x}$ & - & & \\
\hline 15 & THPL/CLUN & 80 & 5 & 5 & 10 & 23.1 & 2.0 & $\mathrm{x}$ & - & & \\
\hline 16 & PSME / PHMA & 50 & 15 & 20 & 15 & 22.7 & 2.1 & $\mathrm{x}$ & - & & \\
\hline 17 & $\begin{array}{l}\text { PSME / PHMA } \\
\text { ABGR/CLUN }\end{array}$ & 30 & 20 & 40 & 10 & 23.1 & 2.8 & $\mathrm{x}$ & - & $\mathrm{x}$ & \\
\hline 18 & $\begin{array}{l}\text { PSME / PHMA } \\
\text { THPL/CLUN }\end{array}$ & 35 & 10 & 25 & 30 & 19.7 & 0.8 & - & $\mathrm{x}$ & $\mathrm{x}$ & \\
\hline 19 & PSME / PEMA & 40 & 20 & 40 & 0 & 21.6 & 1.6 & & - & $\mathrm{x}$ & $x$ \\
\hline 20 & $\begin{array}{l}\text { PSME / PHMA } \\
\text { THPL/ CLUN }\end{array}$ & 25 & 25 & 50 & 0 & 19.7 & 2.6 & $\mathrm{x}$ & $\mathrm{x}$ & & \\
\hline 21 & THPL/CLUN & 40 & 10 & 40 & 10 & 20.8 & 3.2 & $\mathrm{x}$ & $x$ & & \\
\hline 22 & $\begin{array}{l}\text { PSME / PHMA } \\
\text { THPL/ CLUN }\end{array}$ & 30 & 20 & 10 & 40 & 17.7 & 6.1 & & $\mathrm{x}$ & $\mathrm{x}$ & \\
\hline 23 & THPL/CLUN & 30 & 10 & 25 & 35 & 22.7 & 3.6 & & - & $\mathrm{x}$ & $x$ \\
\hline 24 & $\begin{array}{l}\text { THPL/CLUN } \\
\text { SWAMP }\end{array}$ & 40 & 10 & 40 & 10 & 23.4 & 5.1 & $\mathrm{x}$ & - & & \\
\hline 25 & $\begin{array}{l}\text { PSME/ PHMA } \\
\text { THPL/CLUN }\end{array}$ & 50 & 15 & 15 & 20 & 19.3 & 3.5 & $\mathrm{x}$ & - & $\mathrm{x}$ & $x$ \\
\hline
\end{tabular}

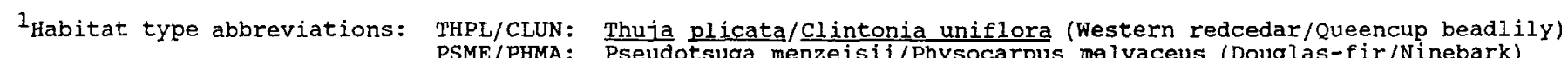

PSME/PHMA: Pseudotsuga menzeisii/Physocarpus malvaceus (Douglas-fir/Ninebark)

ABGR/CLUN: Abies grandis/Clintonia uniflora (Grand fir/Queencup beadlily)

TSHE/CLUN: Tsuga heterophylla/Clintonia uniflora (Western hemlock/Queencup beadlily) 
within each unit averaged 55\%; forested areas with oldgrowth and mature trees averaged 28\%. Trees were shorter $(\overline{\mathrm{x}}=20.4 \mathrm{~m})$ and less dense $(\overline{\mathrm{x}}=2.1$ trees $/ \mathrm{ha})$ than along the river. Slopes were gentle. Most land (98\%) in the units was privately-owned.

Upland units along the river were characterized as similar to the shoreline units but also contained habitat of the grand fir (Abies grandis)/queencup beadlily type. A mean of $63 \%$ of each unit was unforested; older trees averaged 23\% of each unit. Upper canopy trees in each unit were of similar height $(\bar{x}=22.9 \mathrm{~m})$, but not as dense $(\bar{x}=$ 2.4 trees/ha) as along the shoreline of Lake Pend Oreille. Most slopes were relatively gentle. Most land (95\%) was privately-owned.

\section{BEHAVIORAL ACTIVITY BUDGETS}

Time-budget data of bald eagles at areas of intense activity was recorded at five sites on 11 days during 1985$86(110 \mathrm{hrs} ; \overline{\mathrm{x}}=10 \mathrm{hrs})$ and at the mouth of Granite Creek during the kokanee salmon spawning run on two days in 198687 (14.6 hrs) (Table 13). A total of 7,780 individual activities were recorded during 1985-86 $(\mathrm{N}=5,568)$ and 1986-87 ( $N=2,212)$ from 5-min scans of eagles' behavior at the observation sites.

The most common bald eagle activity observed at all sites was perching during 1985-86 (85\%) and 1986-87 (91\%); flying, feeding, hunting, and preening were also recorded (Fig. 33). Locomotion categories were dominated by flight both years; direct flapping flight was most common, followed by soaring and gliding (Fig. 34). Live trees, followed by stumps and snags, were most often used as perch sites in 1985-86; ice which had formed in shallower bays at northern observation sites was also used. In 1986-87, live trees made up nearly all (99\%) of the perch sites used by bald eagles near Granite Creek (Fig. 35).

Documentation of perch tree use on Lake Pend Oreille by bald eagles counted in the aerial censuses indicated a preference for ponderosa pine (47\%) and Douglas-fir (38\%). Black cottonwood. (Populus trichocarpa) which are found in isolated groves and in much fewer numbers on the lake were used to a lesser extent ( $8 \%$ ). Eagles perched most often in live trees $(85 \%)$ and snags $(10 \%)$ within $100 \mathrm{~m}$ of the shoreline (Table 14).

The overall capture success rate was similar between 1985-86 (85\%) and 1986-87 (90\%); aerial capture attempts were less productive during 1985-86 than during 1986-87 when 
Table 13. Dates and sites of behavioral activity budget sessions of bald eagles, 1985-86 and 1986-87.

\begin{tabular}{lll} 
& \multicolumn{2}{c}{ Observation session } \\
\cline { 3 - 3 } Date Site & Time-span Duration (hrs)
\end{tabular}

\section{5-86}

10 Dec

23 Dec.

30 Dec.

6 Jan.

13 Jan.

26 Jan.

4 Feb.

10 Feb.

18 Feb.

10 Mar.

1986-87
Bottle Bay

Sunrise Bay

Bottle Bay

Sunrise Bay

Bottle Bay

Sunrise Bay

Warren Island

Bottle Bay

Pend Oreille River

Warren Island

Pack River Delta
0650-1630

0625-1555

0645-1620

0715-1615

0700-1610

0700-1625

0640-1655

0645-1645

0630-1715

0630-1730

0625-1755
9.7

9.5

9.6

9.0

9.2

9.4

10.3

10.0

10.8

11.0

11.5

12 Dec.

Granite Creek Bay

0700-1625

9.4

28 Dec.

Granite Creek Bay

0715-1225

5.2 


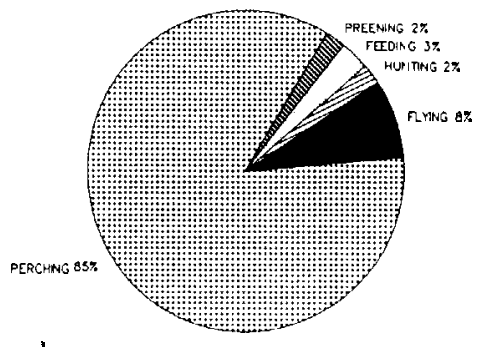

LAKE PEND OREHLLE. 985.83.

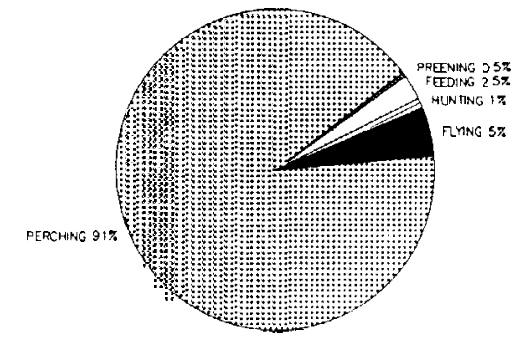

MOUTH OF GRANITE CREEK , :986-87

Figure 33. Time buaget categories of bald eagles on Lake Pend oreille, 1985-86 and 1986-87.

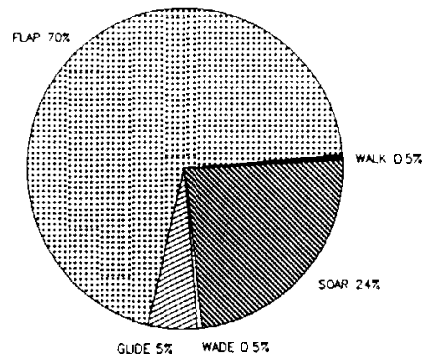

LAKE PEND OREILLE, $1985-86$

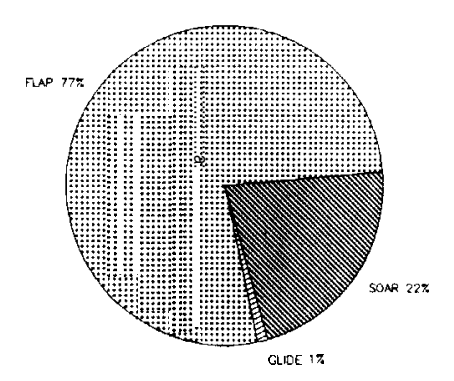

MOUTH OF GRANITE CREEK. 1986-87.

Figure 34. Time budget categories for locomotion of bald eagles on Lake Pend oreille, 1985-86 and 1986-87. 


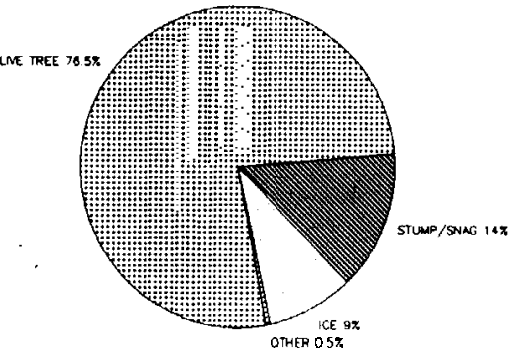

LAKE PEND OREILLE, 1985-86.

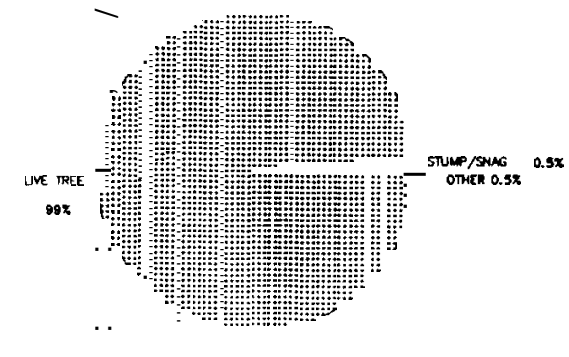

MOUIH OF GRANITE CREEK, 1986-87.

Figure 35. Perch substrates used by bald eagles on Lake Pend oreille, $1985-86$ and $1986-87$.

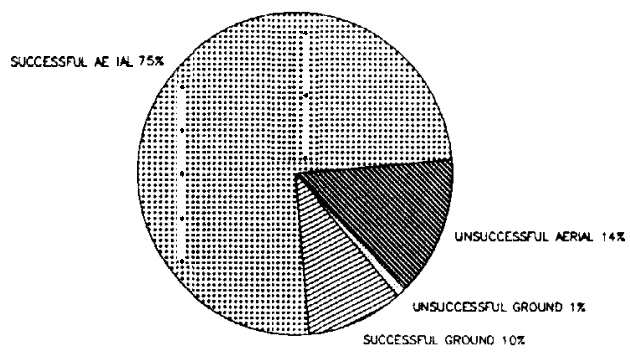

LAKE PEND OREILLE, 1985-86.

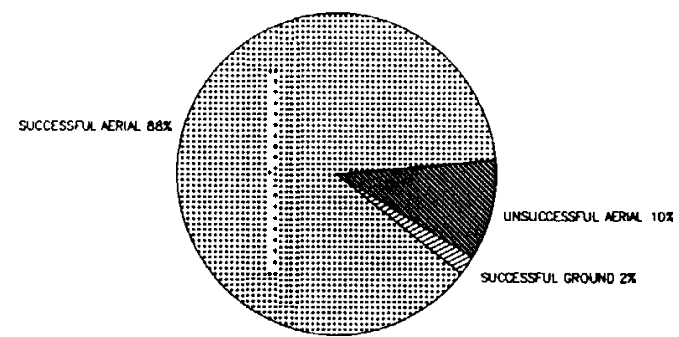

MOUTH OF GRANITE CREEK, 1986-87.

Figure 36. Hunting success by bald eagles on Lake Pend Oreille, 1985-86 and 1986-87. 
Table 14. Preference of a) species and b) structure classifications of perch trees by bald eagles in aerial censuses, 1985-86 and 1986-87.

a)

\begin{tabular}{lll} 
& \multicolumn{2}{c}{ Frequency } \\
\cline { 2 - 3 } Tree & & Percent
\end{tabular}

$\begin{array}{lrr}\text { Ponderosa pine } & 1565 & 47.0 \\ \text { Douglas-fir } & 1256 & 37.7 \\ \text { Black Cottonwood } & 249 & 7.5 \\ \text { Western redcedar } & 100 & 3.0 \\ \text { Western larch } & 87 & 2.6 \\ \text { Western white pine + } & & 1.9 \\ \quad \text { Lodgepole pine } & 62 & \\ \text { Grand fir + } & & 0.3 \\ \text { Paper birch } & 12 & \end{array}$

b)

Tree structure

classification

Frequency

Number

Percent

$\begin{array}{lrr}\text { Live tree } & 3962 & 85.4 \\ \text { Snag } & 458 & 9.9 \\ \text { Live, dead top } & 109 & 2.4 \\ \text { Dying tree } & 48 & 1.0 \\ \text { Live, broken top } & 36 & 0.8\end{array}$


eagles were feeding heavily on numerous salmon that were spawning near the mouth of Granite Creek (Fig. 36). After capturing prey, eagles most often perched in trees to feed during 1985-86 (69\%) and 1986-87 (87\%); stumps, snags, and other substrates were used to a lesser extent (Fig. 37). Preening activity was observed most often when eagles were perched in live trees (66\%) and on stumps or snags (31\%) in 1985-86 (Fig. 38) and exclusively in live trees in 1986-87 $(100 \%)$.

\section{FEEDING HABITS}

\section{Behavioral Activity Budgets}

A total of 300 observations of foraging events were recorded during behavioral activity budget sessions in 1985-86 (11 days) and 1986-87 (9 days) (Table 15). Sixtyfive percent of the events were by adult bald eagles $(\mathrm{N}=192)$; $35 \%$ were by subadults $(\mathrm{N}=106)$. Most $(69 \%)$ of the foraging events resulted in the capture of prey $(\mathrm{N}=202)$.

Capture attempts by adult bald eagles were more successful (71\%) than attempts by subadults $(60 \%)$. The mean number of capture attempts per successful outcome was 1.1 . Most (78\%) successful attempts by eagles were aerial, followed by captures on the ground (12\%) and while standing on ice (10\%) (piracy of other eagles).

Fish species $(N=170)$ were the preferred prey $(84 \%)$ (Fig. 39). Some prey (9\%) could not be readily identified (Table 15). Capture of waterfowl by eagles during recording sessions was not observed although occasional harassment was documented.

Analysis of Cast Pellets And Remains of Eagle Prey

A total of 368 pellets regurgitated by eagles were collected at two major communal roosts (Bottle Bay and Warren Island) in 1985-86 $(\mathrm{N}=200)$ and 1986-87 ( $=168)$. Analysis of the pellets for the two years combined yielded bird remains in 208 pellets, fish remains (usually scales or vertebrae) in 175 pellets, and mammal remains in 21 pellets. Contents of pellets indicated the importance of waterfowl in the diet, however, they underplayed the importance of fish because these -remains are usually digested and result in no pellet being cast. (Lish and Lewis 1975, Steenhof 1976). In addition, pellets consisting primarily of fish remains often tended to break apart upon striking the ground after being cast, or, in the case of those that landed intact, disintegrated rapidly upon dessication. In contrast, waterfowl pellets held together, and often became more noticeable as they dried out. 


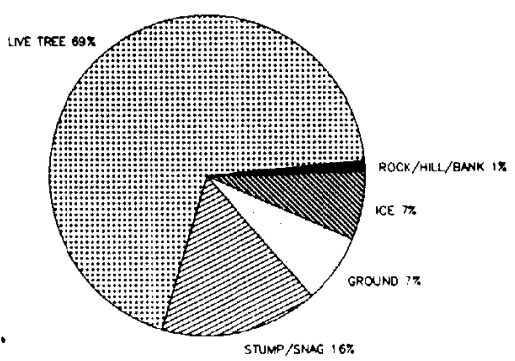

LAKE PEND OREILLE, $1985-86$

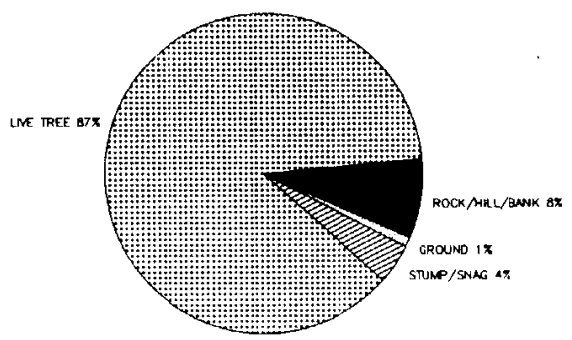

MOUTH OF GRANITE CREEK, $1986-87$

Figure 37. Feeding substrates of bald eagles on Lake Pend oreille, from time budget sessions, 1985-86 and 1986-87.

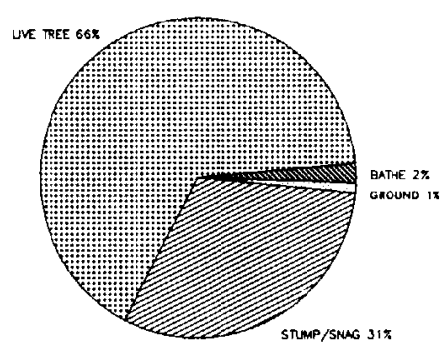

STMmp/sma $31 x$

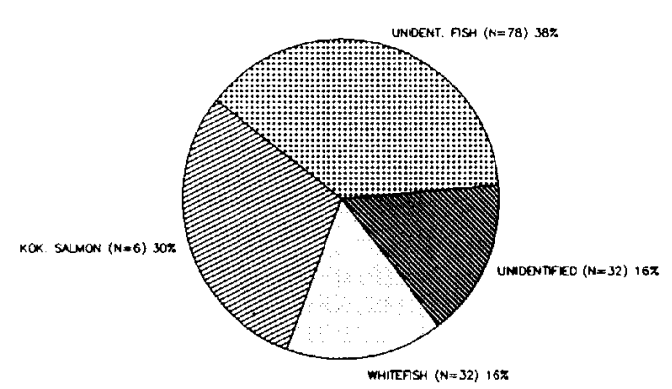
Figure 39. Prey of bald eagles during time budget sessions. $1985-86$ and $1986-87$.

reening substrates of bald eagles on Lake Pend Oreille, $1985-86$. 
Table 15. Observations of foraging events by bald eagles during ti ne budget sessi ons, 1985-86 and 1986-87.

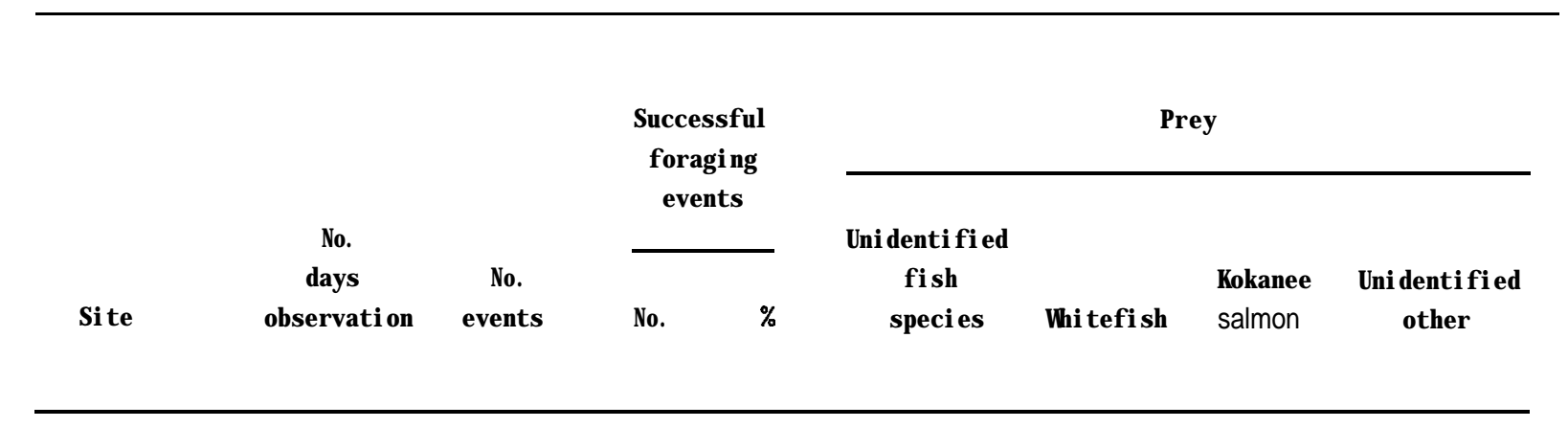

$\underline{1985-86}$

\begin{tabular}{|c|c|c|c|c|c|c|c|c|}
\hline Pend Oreille River & 1 & 18 & 15 & 83 & 7 & 3 & 0 & 5 \\
\hline Bottle Bay & 4 & 76 & 48 & 63 & 42 & 7 & 0 & 1 \\
\hline Pack Ri ver Del ta & 2 & 19 & 19 & 100 & 7 & 0 & 0 & 12 \\
\hline Whrren I s| and & 1 & 10 & 5 & 50 & 4 & 0 & 0 & 1 \\
\hline Sunri se Bay & 3 & 56 & 34 & 61 & 11 & 22 & 0 & 1 \\
\hline Denton Sl ough & 3 & 15 & 12 & 80 & 1 & 0 & 0 & 11 \\
\hline $\begin{array}{l}\text { Li ghtni ng Creek } \\
\text { Del ta }\end{array}$ & 1 & 20 & 7 & 35 & 6 & 0 & 1 & 1 \\
\hline
\end{tabular}

$\underline{1986-87}$

$\begin{array}{lllllllll}\text { Granite Creek } & 4 & 68 & 62 & 91 & 0 & 0 & 59 & 0\end{array}$


Bird remains were found in pellets less often in 1985-86 ( $\mathrm{N}=95)$ than in 1986-87 ( $\mathrm{N}=113)$; American coots (Fulica americana) were the most common bird remains identified (Table 16). Remains of fish were found more often in 1985-86 ( $\mathrm{N}=118)$ than in 1986-87 ( $=57)$; Lake Superior whitefish and kokanee salmon (in 1986-87) were the most common fish species, however, many fish remains could not be classified with certainty to species. Mammal remains were identified in pellets less often in 1985-86 (N =7) than in 1986-87 ( $=17)$; whitetail deer remains were most common, particularly in 1986-87. Lower numbers of bird remains in 1985-86 pellets when harsher weather conditions on the lake persisted and resulted in birds' earlier departure south, and higher numbers of available whitefish in the lake which died from spawning stress (Horner, personal communication, 1987), support the view of the bald eagle as an opportunistic raptor which utilizes the most abundant and accessible prey.

Collection of prey remains at feeding sites of bald eagles yielded additional prey species not identified in pellets. These included one bird species (Canada goose [Branta canadensis]) and four fish species (largemouth bass, largescale sucker, northern squawfish, pumpkinseed [Lepomis sibbosus]).

\section{SALMON CARCASS AVAILABILITY FROM CABINET GORGE HATCHERY}

A total of 4,214 tagged kokanee salmon carcasses were released into the Clark Fork River adjacent to the Cabinet Gorge Hatchery on 7, 21, and 25 November 1986 (Table 17). Almost all carcasses dropped rapidly toward the riverbottom after release: many of those released near shore were seen lying on the bottom where observed progress downstream was minimal. A total of ten tags were located during 11 surveys: nine tags (of 1000 pink tags) had been released in mid-channel on 7 November: one tag (of 214 green tags) had been released near the shore on 21 November.

Two of the recovered tags were found along the south side of the river at RM 149 within $100 \mathrm{~m}$ downstream of the release site: the green tag and carcass with $60 \%$ of the flesh remaining were found $3 \mathrm{~m}$ above high water mark; one pink tag was located $10 \mathrm{~m}$ above high water mark under a western redcedar perch tree. Eight tags (all pink) were located in the vicinity of a gravel island which divides the river along RM 147 approximately $3 \mathrm{~km}$ below the release site: three carcasses were found lying stationary in water about $1 \mathrm{~m}$ deep along the north side of the island; two carcasses were observed rolling with the current along the bottom of the river on the north side of the island; one tag 
Table 16. Frequency of occurrence of prey species in 368 cast pellets of bald eagles at Lake Pend Oreille, 1985-86 ( $\mathrm{N}=200)$ and 1986-87 (N = 168).

$\begin{array}{lrrr}\text { Category and species } & 1985-86 & 1986-87 & \text { Total }\end{array}$

Birds

American coot (Fulica americana)

Mallard (Anas platvrhvnchos)

Redhead (Avthva americana)

Lesser scaup (Avthva affinis)

Green-winged teal (Anas crecca)

Common merganser (Mersus merganser)

Bufflehead (Bucephala albeola)

Common goldeneye (Bucephala clansula)

Ring-necked duck (Avthva collaris)

Unidentified

The

$\stackrel{\sim}{A}$

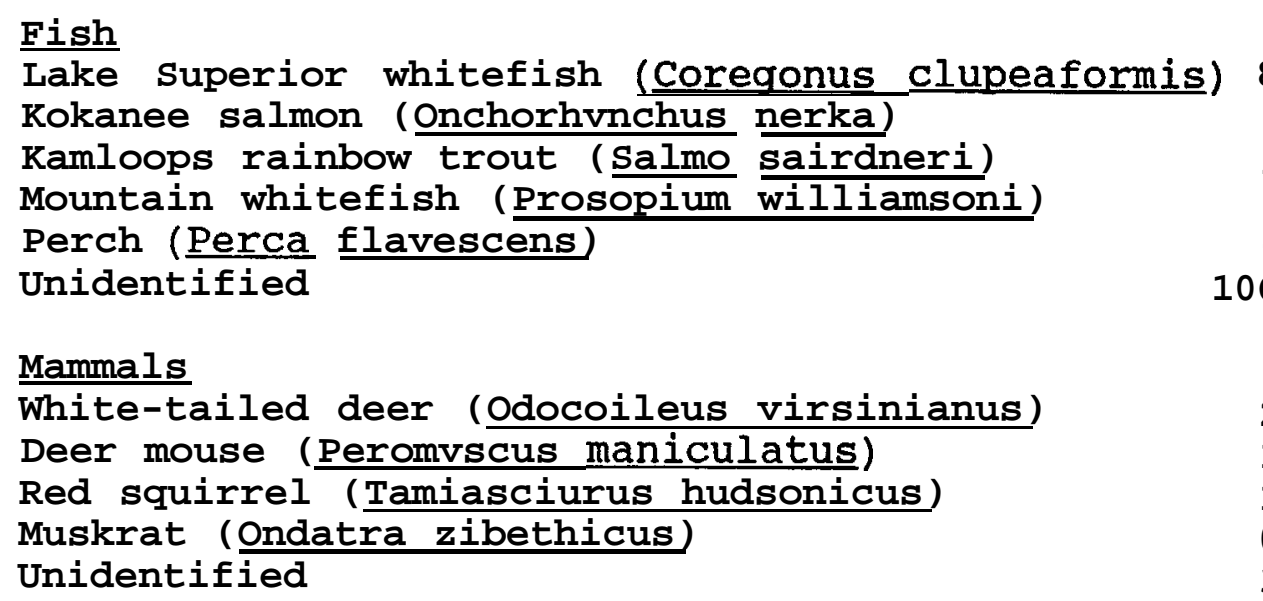

Mammals

White-tailed deer (Odocoileus virsinianus)

Deer mouse (Peromvscus maniculatus)

Red squirrel (Tamiasciurus hudsonicus)

Muskrat (Ondatra zibethicus)

Unidentified

$\begin{array}{rrr}35 & 53 & 88 \\ 9 & 19 & 28 \\ 17 & 8 & 25 \\ 9 & 11 & 20 \\ 0 & 4 & 4 \\ 3 & 1 & 4 \\ 1 & 1 & 2 \\ 1 & 0 & 1 \\ 1 & 0 & 1 \\ 19 & 17 & 36\end{array}$

$\begin{array}{rrr}8 & 14 & 22 \\ 1 & 13 & 14 \\ 2 & 0 & 2 \\ 1 & 0 & 1 \\ 0 & 1 & 1 \\ 106 & 29 & 135\end{array}$

Unidentified

$\begin{array}{rrr}2 & 14 & 16 \\ 1 & 1 & 2 \\ 1 & 1 & 2 \\ 0 & 1 & 1 \\ 3 & 0 & 3\end{array}$


Table 17. Releases and surveys of tagged kokanee salmon carcasses on the lower Clark Fork River, 1986.

\begin{tabular}{|c|c|c|c|c|c|c|c|c|c|}
\hline \multicolumn{2}{|c|}{ Release } & \multicolumn{2}{|c|}{$\begin{array}{c}\text { Released } \\
\text { Tags }\end{array}$} & \multicolumn{4}{|c|}{ Survey } & \multicolumn{2}{|c|}{$\begin{array}{c}\text { Recovered } \\
\text { tags }\end{array}$} \\
\hline Date & Location & \# & \multirow{2}{*}{$\begin{array}{l}\text { Color } \\
\begin{array}{l}\text { white } \\
\text { pink }\end{array}\end{array}$} & \multicolumn{2}{|c|}{ Date } & \multirow{2}{*}{$\begin{array}{c}\text { Time } \\
\text { PM }\end{array}$} & Distance & \multirow{2}{*}{$\begin{array}{l}\# \\
\\
\end{array}$} & \multirow{2}{*}{$\begin{array}{c}\text { Color } \\
-\end{array}$} \\
\hline 7 Nov. & $\begin{array}{l}10 \mathrm{~m} \text { offshore } \\
\text { Mid-channel }\end{array}$ & $\begin{array}{l}1000 \\
1000\end{array}$ & & 7 & Nov. & & $16 \mathrm{~km}$ & & \\
\hline & & & & 8 & Nov. & AM & $16 \mathrm{~km}$ & 0 & - \\
\hline & & & & 9 & Nov. & $\mathrm{AM}$ & $16 \mathrm{~km}$ & 0 & - \\
\hline 21 Nov. & $10 \mathrm{~m}$ offshore & 1000 & $\begin{array}{l}\text { white/ } \\
\text { black }\end{array}$ & 21 & Nov. & PM & $14 \mathrm{~km}$ & 3 & pink \\
\hline & $10 \mathrm{~m}$ offshore & 214 & green & & & & & & \\
\hline \multirow{8}{*}{25 Nov. } & & & & 22 & Nov. & $\mathrm{AM}$ & $14 \mathrm{~km}$ & 1 & pink \\
\hline & & & & 22 & Nov. & PM & $14 \mathrm{~km}$ & 0 & - \\
\hline & & & & 23 & Nov. & $\mathrm{AM}$ & $14 \mathrm{~km}$ & $\begin{array}{l}1 \\
2\end{array}$ & $\begin{array}{l}\text { green } \\
\text { pink }\end{array}$ \\
\hline & $10 \mathrm{~m}$ offshore & 480 & $\begin{array}{l}\text { orange/ } \\
\text { black }\end{array}$ & 25 & Nov. & PM & $14 \mathrm{~km}$ & 3 & pink \\
\hline & $10 \mathrm{~m}$ offshore & 480 & $\begin{array}{l}\text { white/ } \\
\text { blue }\end{array}$ & & & & & & \\
\hline & & & & 26 & Nov. & $\mathrm{AM}$ & $14 \mathrm{~km}$ & 0 & - \\
\hline & & & & 30 & Nov. & $\mathrm{AM}$ & $14 \mathrm{~km}$ & 0 & - \\
\hline & & & & 3 & Dec. & $\mathrm{AM}$ & $14 \mathrm{~km}$ & 0 & - \\
\hline
\end{tabular}


and jaw of the fish were found about $15 \mathrm{~m}$ from the river under a black cottonwood perch tree; two tags were found under a black cottonwood perch tree along the north shore of the river about $3 \mathrm{~m}$ above high water mark, apparently discarded there by eagles eating the carcasses from the tree above.

Insufficient numbers of tags were recovered to make
statistically valid conclusions about salmon carcass
stranding and availability to bald eagles. However, the
tags that were recovered appear to indicate that mid-channel
releases would be more effective in allowing carcasses to
drift downstream to shallower water where they would become
more accessible to eagles. Although carcasses did not move
downstream readily after release from near the shoreline,
the single green-tagged carcass recovered that was marked
and released the same morning at the hatchery may indicate
more fish will float near the surface in immediate releases
of artificially-spawned salmon from the hatchery. More fish
could be made available to bald eagles and other predators
if future releases were conducted at a site as far out into
the current as possible with freshly-killed or anaesthetized
fish that have their air bladders intact to allow a higher
floatation rate.




\section{SUMMARY}

Lake Pend Oreille, the lower Clark Fork River, and the upper Pend Oreille River are important areas for large numbers of wintering bald eagles. The relative lack of human disturbance to eagles throughout most of the area, the large area that eagles have to escape disturbance, and the numerous diurnal perches from which eagles may hunt and feed, all add to the present and future importance of the area to bald eagles. The abundance and variety of eagle prey found there contribute to the significance of this location where many eagles may remain until they begin migrating north in the spring. The enhancement of the kokanee salmon fishery in Lake Pend Oreille through the operation of the Cabinet Gorge Hatchery should contribute toward providing eagles with a plentiful food source during the autumn months. Other fish species found in the lake and rivers, particularly whitefish, and waterfowl especially during milder winters, will continue to provide eagles with alternate sources of prey. As a result of the continued loss of eagle habitat nationwide and the unpredictability of food sources such as spawning runs of fish and concentrations of migrating waterfowl, with proper management the potential is high for the Lake Pend Oreille area to continue to play a major role for wintering bald eagles in the region.

The following are recommendations for the management of the Lake Pend Oreille bald eagle concentration and important eagle habitat.

1. Aerial censuses of bald eagles on Lake Pend Oreille, the lower Clark Fork River, and the upper Pend Oreille River should be continued so that a record of eagle abundance and distribution can be maintained. The annual National Wildlife Federation bald eagle count of the area by itself is insufficient for making knowledgable management decisions. Censuses will also provide the opportunity to search for the return of wing-marked eagles from Lake Pend Oreille and for the arrival of those from Glacier National Park.

2. It will be several years before the enhancement of the kokanee 'salmon fishery on the lake by the operation of the Cabinet Gorge Hatchery will be realized. Once this has occurred, however, additional study will be required to assess the effects to bald eagles of the increase in food availability. Information on eagle numbers, distribution, food habits, and local movements, and availability of prey species will be necessary to make comparisons with past use of the area by bald eagles. 
3. Bald eagle roosts should be protected from human disturbance, and harvest of roost trees should be avoided in order to maintain quality bald eagle habitat. Private individuals having roosts on their property should be approached regarding management of these sites. Specific management plans should be developed for all eagle roosts.

4. Perch trees, especially those located where eagles concentrate, should be protected. These sites are preferred as a result of the structure of the trees, protection from disturbance, and the availability of prey in the area.

5. Bald eagle nesting sites should be protected, productivity surveys continued, and the size of nesting territories determined. Searches for alternate and new nest sites should be continued. Site-specific management plans should be developed for each nesting territory.

6. The presence of such large numbers of wintering bald eagles in northern Idaho is impressive and worthy of note by the media. Efforts to increase public awareness and appreciation of the bald eagle concentration on Lake Pend Oreille should be continued. 


\section{IITERATURE CITED}

Altmann, J. 1974. Observational study of behavior: sampling methods. Behaviour 49:227-267.

Bortolotti, G. R. 1984. Sexual size dimorphism and agerelated size variation in bald eagles. Journal of Wildlife Management 48:72-81.

Bowles, E. C., V. L. Ellis, and D. Washick. 1986. Kokanee stock status and contribution of Cabinet Gorge Hatchery, Lake Pend Oreille, Idaho. Annual Report to Bonneville Power Administration, Contract DE-A179-85BP22493, Project 85-339. Idaho Department of Fish and Game, Boise, Idaho. 4IPP.

, V. L. Ellis, D. Hatch, and D. Irving. 1987. In press. Kokanee stock status and contribution of Cabinet Gorge Hatchery, Lake Pend Oreille, Idaho. Annual Report to Bonneville Power Administration, Contract DE-A179Project 85-339. Idaho Department of Fish and Game, Boise, Idaho. 60pp.

Brown, C. J. D. 1971. Fishes of Montana.

Casteel, R. W. 1973. The scales of the native freshwater fish families of Washington. Northwest Science 47:230238 .

COMARC Design Systems, Inc. 1986. COMARC geographic information system. San Francisco, California.

Cooper, S., K. Neiman, and R. Steele. 1985. Forest habitat types of northern Idaho. (Unpublished manuscript.)

Edwards, C. C.. 1969. Winter behavior and population dynamics of American eagles in western Utah. Ph.D. dissertation. Brigham Young University, Provo, Utah. (Unpublished).

Errington, P. L. 1932. Techniques of raptor food habits study. Condor 34:75-86.

Frenzel, R. W., and R. G. Anthony. 1982. Method for livecapturing bald eagles and osprey over open water. Research Information Bulletin No. 82-13. U.S. Department of Interior, Fish and Wildlife Service. 2pp. 
Griffin, C. R., T. S. Baskett, and R. D. Sparrowe. 1982 . Ecology of bald eagles wintering near a waterfowl concentration. U.S. Department of Interior, U.S. Fish and Wildlife Service, Special Scientific Report-Wildlife No. 247. Washington, D. C. 12pp.

Grubb, T. G. 1984. Winter activity of bald eagles (Haliaeetus leucocephalus) at Navaho Lake, New Mexico. The Southwest Naturalist 29:335-341.

Hancock, D. 1964. Bald eagles wintering in the Southern Gulf Islands, British Columbia. Wilson Bulletin 76:111120 .

Heezen, K. L., and J. R. Tester. 1967. Evaluation of radio-tracking by triangulation with special reference to deer movements. Journal of Wildlife Management $31: 124-141$.

Keister, G. P., and R. G. Anthony. 1983. Characteristics of bald eagle communal roosts in the Klamath Basin, Oregon and California. Journal of Wildlife Management $47: 1072-1079$.

Lish, J. W., and J. C. Lewis. 1975. Status and ecology of bald eagles wintering in Oklahoma. Proceedings of the Southeastern Association of Game and Fish Commissions $29: 415-423$.

Meyer, J. R. 1979. Northwest Montana/North Idaho transmission corridor bald eagle study. Bonneville Power Administration. Portland, Oregon. 90pp.

McClelland, B. R. 1973. Autumn concentrations of bald eagles in Glacier National Park. Condor 75:121-123.

P. T. McClelland, and J. G. Crenshaw. 1984. Ecology of bald eagles associated with the autumn concentration in Glacier Natinal Park, Montana. 1982-1983 progress report and basic data summary, May 1984. U.S. Department of Interior, National Park Service, Glacier National Park, West Glacier, Montana. 148pp. (Unpublished).

Sabine, N.; and W. D. Klimstra. 1985. Ecology of bald eagles wintering in southern Illinois. Transactions of the Illinois Academy of Science $78: 13-24$.

Servheen, C. W. 1975. Ecology of the wintering bald eagles on the Skagit River, Washington. M.S. Thesis, University of Washington, Seattle. (Unpublished). 
Shea, D. S. 1973. A management-oriented study of bald eagle concentrations in Glacier National Park. M.S. Thesis, University of Montana, Missoula. 148pp. (Unpublished).

Simpson, J., and R. Wallace. 1978. Fishes of Idaho. University Press of Idaho, Moscow. $237 \mathrm{pp}$.

Spencer, D. A. 1976. Wintering of the migrant bald eagle in the lower 48 states. National Agricultural Chemicals Association, Washington, D.C.

Southern, W. E. 1963. Winter populations, behavior, and seasonal dispersal of bald eagles in northwestern Illinois. Wilson Bulletin 75:42-55.

Stains, H. J. 1958. Field key to guard hairs of middle western furbearers. Journal of Wildlife Management $22: 95-97$.

Stalmaster, M. V., J. R. Newman, and A. J. Hansen. 1979. Population dynamics of wintering bald eagles on the Nooksack River, Washington. Northwest Science 53:126131 .

Steenhof, K. S. 1976. The ecology of wintering bald eagles in southeastern South Dakota. M.S. Thesis, University of Missouri, Columbia. (Unpublished).

, S. S. Berlinger, and L. H. Fredrickson. 1980. Habitat use by wintering bald eagles in South Dakota. Journal of Wildlife Management 44:798-805.

SYSTAT, Inc. 1986. SYSTAT: The system for statistics. SYSTAT, Inc., Evanston, Illinois.

U.S. Fish and Wildlife Service. 1984. Endangered and threatened wildlife and plants. U.S. Department of Interior, 50 CFR 17.11 and 17.12 . $24 \mathrm{pp}$.

U.S. Forest Service. 1985. Overview: Proposed forest plan, Idaho Panhandle Forests. U.S. Department of Agriculture, U.S. Forest Service. 11pp.

Young, L. S. 1983. Movements of bald eagles associated with autumn concentrations in Glacier National Park. M.S. Thesis, University of Montana, Missoula. 102pp. (Unpublished). 
APPENDICES 
APPENDIX A

FIELD DATA FORMS AND EAGLE BEHAVIOR CODES

A-I 
APPENDIX A-1

BALD EAGLE CENSUS DATA SHEET

DATE:

OBSERVERS :

PILOT:

AIRCRAFT TYPE:

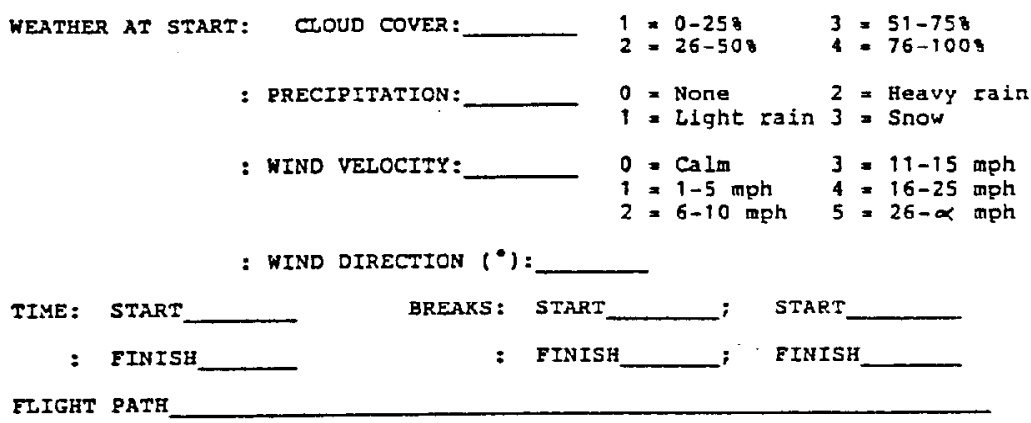


APPENDIX A-2

\section{BALD EAGLE MARKING AND BANDING DATA SHEET}

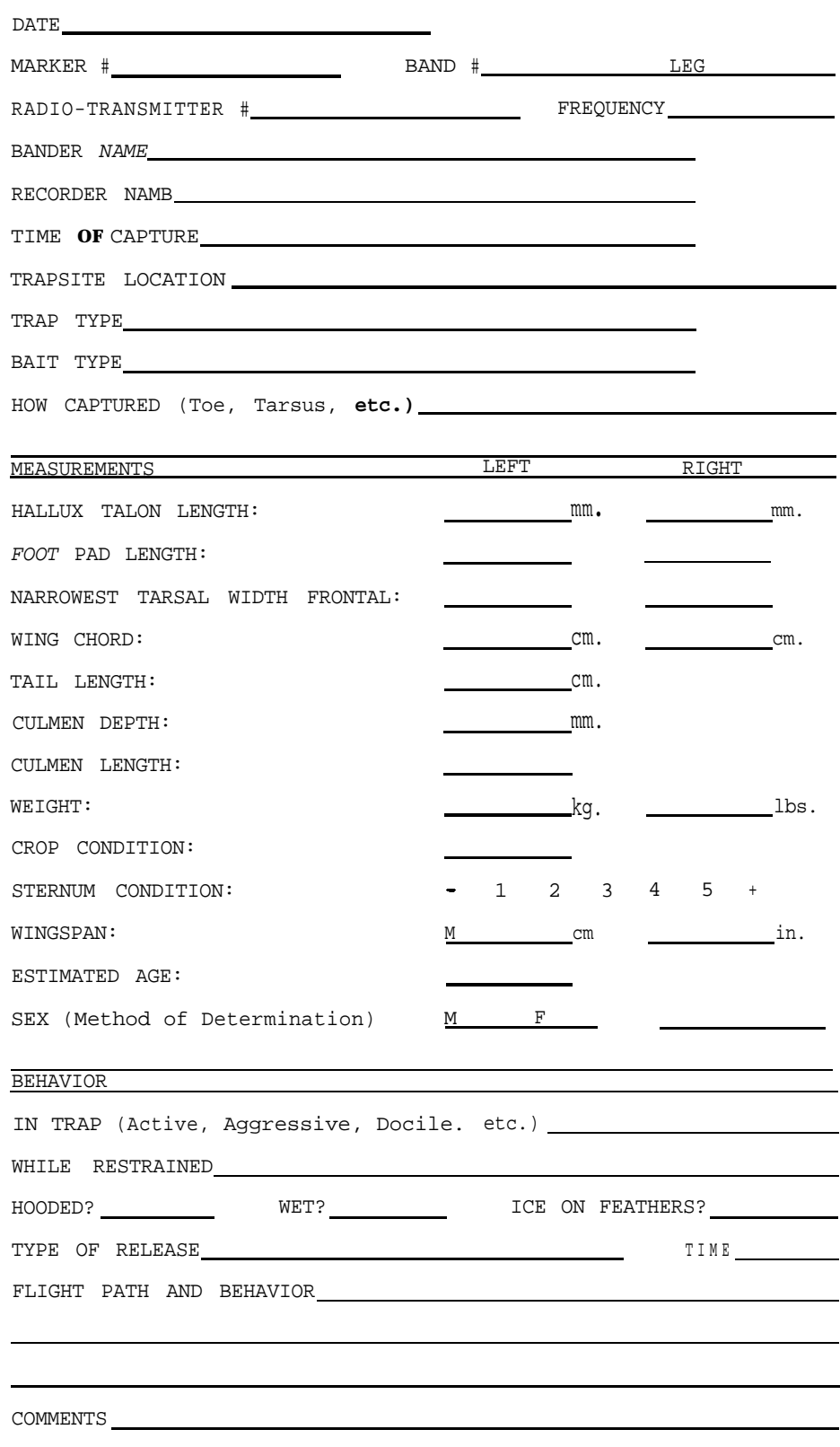


APPENDIX A-3

TRANSMITTER-EQUIPPED EAGLE LOCATION DATA SHEET

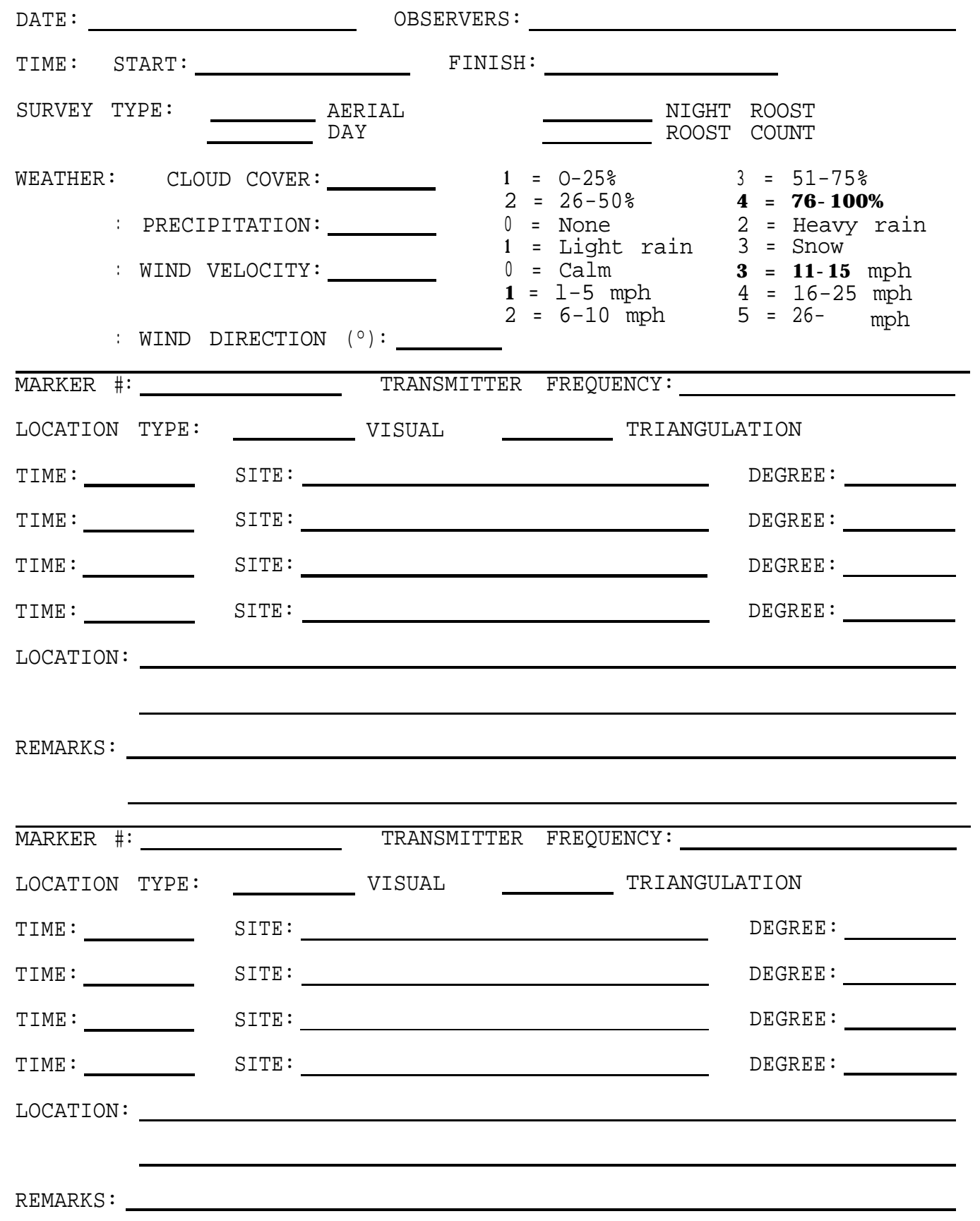


APPENDIX A-4

CODES FOR BEHAVIORAL ACTIVITIES OF BALD EAGLES

\begin{tabular}{ll} 
Code & \multicolumn{1}{c}{ Activity } \\
& \\
01 & Adult bald eagle \\
02 & Subadult bald eagle \\
03 & Unknown age class \\
10 & Soar \\
11 & Glide \\
12 & Flap-fly \\
13 & Flap-fly with fish \\
14 & Flap-fly with other \\
20 & Perch, rock/hill/bank \\
21 & Perch, stump/snag \\
22 & Perch, tree \\
23 & Perch, wing-droop, rock/hill/bank \\
24 & Perch, wing-droop, stump/snag \\
25 & Perch, wing-droop, tree \\
26 & Preen, rock/hill/bank \\
27 & Preen, stump/snag \\
28 & Preen, tree \\
29 & Preen, ground \\
30 & Stand, ground \\
31 & Stand, ground with fish \\
32 & Stand, water \\
33 & Stand, water with fish \\
34 & Drag fish out of water \\
35 & Stand, ice \\
36 & Stand, ice with fish \\
40 & Walk \\
41 & Wade \\
42 & Bathe \\
43 & Swim \\
50 & Consume fish, water \\
51 & Consume fish, ground \\
52 & Consume fish, stump/snag \\
54 &
\end{tabular}


APPENDIX A-4 (continued)

\begin{tabular}{ll} 
Code & \multicolumn{2}{c}{ Activity } \\
\hline 60 & Aerial capture, successful \\
61 & Aerial capture, unsuccessful \\
62 & Aerial capture, pirate \\
63 & Aerial capture, pirated \\
64 & Aerial capture, piracy attempt \\
70 & Ground capture, successful \\
71 & Ground capture, unsuccessful \\
72 & Ground capture, pirate \\
73 & Ground capture, pirated \\
74 & Ground capture, piracy attempt \\
75 & Capture, unknown method \\
80 & Drop prey, perch, unforced \\
81 & Drop prey, perch, forced
\end{tabular}




\section{APPENDIX B \\ LOCATIONS OF BALD EAGLES IN WEEKLY AERIAL CENSUSES \\ OF LAKE PEND OREILLE, 1985-86 AND 1986-87}

B-I 
APPENDIX B-1

LOCATIONS OF BALD EAGLES IN WEEKLY AERIAL CENSUSES

OF LAKE PEND OREILLE, 1985-86 ( $\mathrm{N}=19$ CENSUSES)

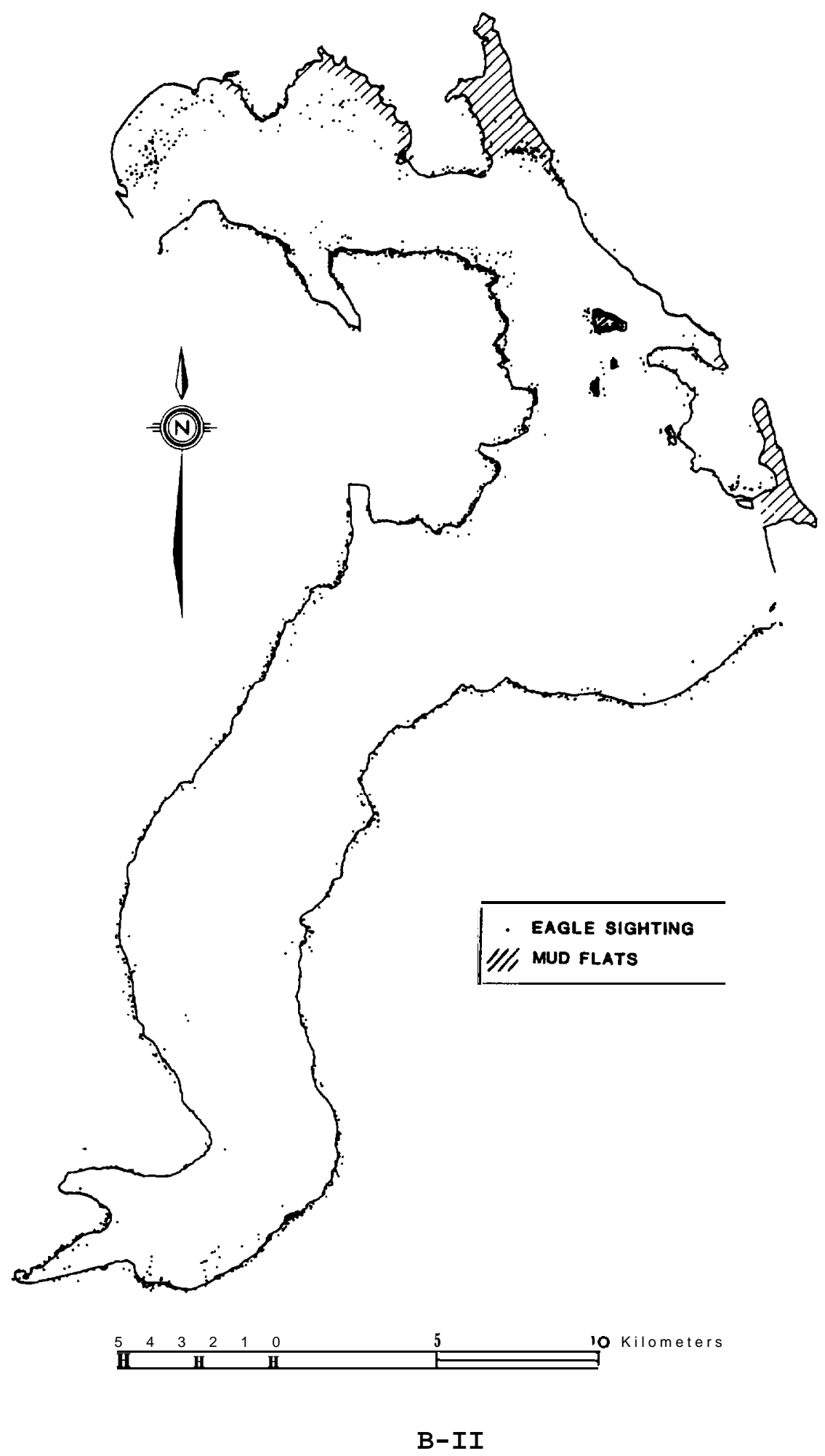



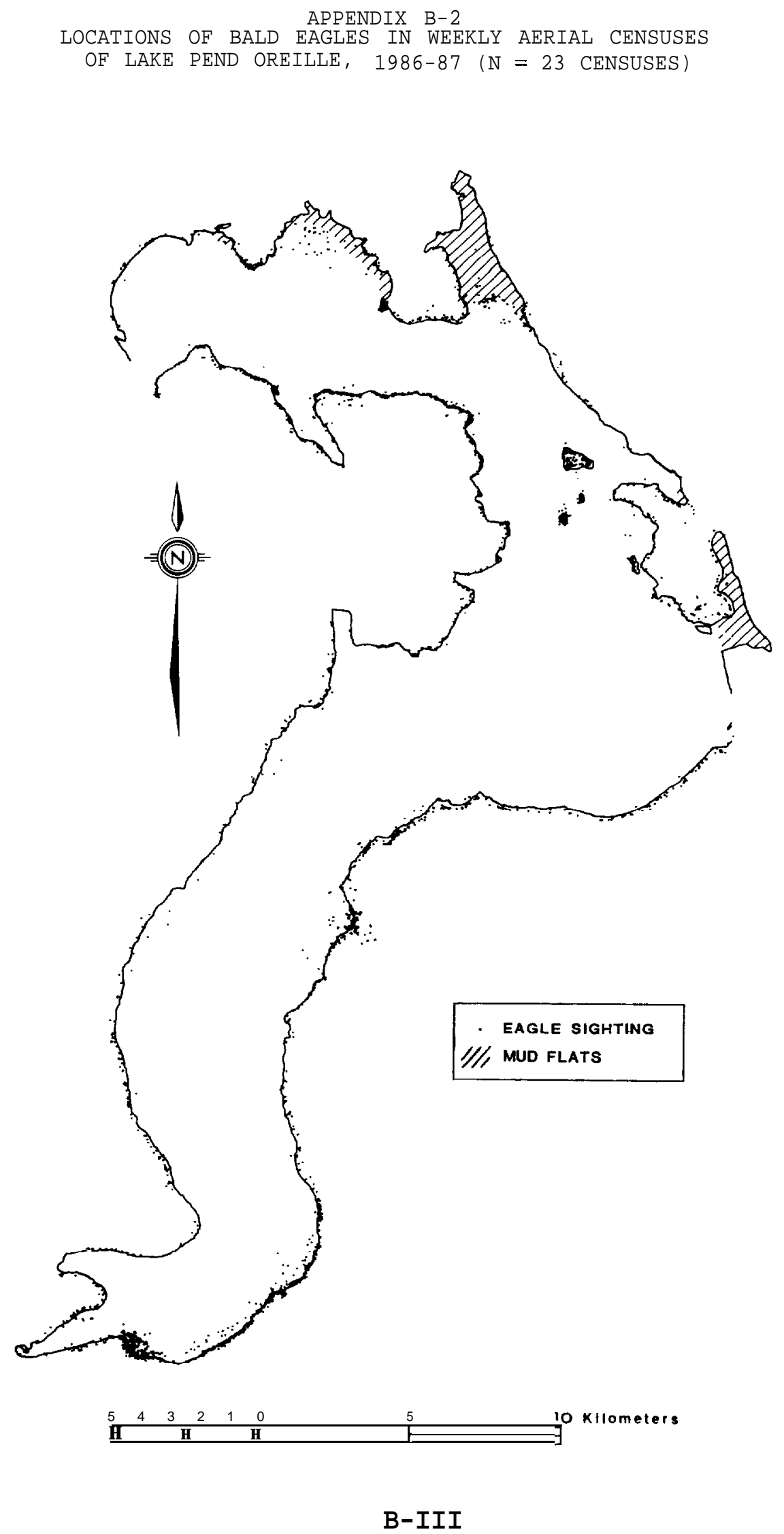
BIOLOGICAL DATA ON CAPTURED BALD EAGLES ON LAKE PEND OREILLE, 1986.

\begin{tabular}{|c|c|c|c|c|c|c|c|}
\hline \multirow{2}{*}{$\begin{array}{c}\text { Marker } \\
\#\end{array}$} & \multirow{2}{*}{$\begin{array}{c}\text { Age } \\
\text { (yrs) }\end{array}$} & \multicolumn{2}{|c|}{$\begin{array}{l}\text { Hallux } \\
\text { length } \\
\text { (mm) }\end{array}$} & \multicolumn{2}{|c|}{$\begin{array}{c}\text { Foot pad } \\
\text { length } \\
(\mathrm{mm})\end{array}$} & \multicolumn{2}{|c|}{$\begin{array}{l}\text { Tarsus } \\
\text { width } \\
(\mathrm{mm})\end{array}$} \\
\hline & & Left & Right & Left & Right & Left & Right \\
\hline 01 & $6+$ & 42.2 & 42.8 & 115.0 & 95.0 & 17.4 & 17.7 \\
\hline 02 & $6+$ & 41.6 & 42.5 & 99.0 & 105.0 & 19.5 & 18.6 \\
\hline 03 & $6+$ & 39.9 & 39.4 & 98.0 & 99.0 & 18.7 & 17.8 \\
\hline 04 & $6+$ & 41.8 & 41.9 & 102.0 & 100.0 & 17.6 & 16.7 \\
\hline 05 & $6+$ & 40.7 & 40.4 & 97.0 & 96.0 & 18.6 & 17.9 \\
\hline 06 & $4-5$ & 39.9 & 39.1 & 96.0 & 96.0 & 17.1 & 17.0 \\
\hline 07 & $6+$ & 39.2 & 39.3 & 102.0 & 98.0 & 17.7 & 18.0 \\
\hline 08 & $4-5$ & 45.4 & 44.4 & 110.0 & 112.0 & 18.4 & 17.8 \\
\hline
\end{tabular}

\begin{tabular}{|c|c|c|c|c|c|c|c|}
\hline \multirow{2}{*}{$\begin{array}{c}\text { Marker } \\
\#\end{array}$} & \multirow{2}{*}{$\begin{array}{l}\text { Culmen } \\
\text { depth } \\
\text { (mm) }\end{array}$} & \multirow{2}{*}{$\begin{array}{c}\text { Weight } \\
(\mathrm{kg})\end{array}$} & \multirow{2}{*}{$\begin{array}{l}\text { Wingspan } \\
\text { (cm) }\end{array}$} & \multicolumn{2}{|c|}{$\begin{array}{l}\text { Wing chord } \\
\text { (cm) }\end{array}$} & \multirow{2}{*}{$\begin{array}{c}\text { Tail } \\
\text { length } \\
\text { (cm) }\end{array}$} & \multirow{2}{*}{$\begin{array}{l}\text { Crop } \\
\text { condition }\end{array}$} \\
\hline & & & & Left & Right & & \\
\hline 01 & 33.0 & 4.90 & 197.0 & 56.3 & 56.2 & 27.4 & empty \\
\hline 02 & 36.0 & 5.25 & 205.0 & 58.1 & 58.1 & 28.2 & empty \\
\hline 03 & 33.0 & 4.60 & 190.0 & 55.3 & 57.2 & 27.6 & full* \\
\hline 04 & 33.2 & 3.60 & 199.0 & 54.7 & 54.8 & 26.3 & empty \\
\hline 05 & 33.7 & 4.70 & 196.0 & 58.4 & 57.7 & 26.6 & empty \\
\hline 06 & 33.4 & 3.80 & 196.0 & 56.7 & 56.4 & 27.9 & empty \\
\hline 07 & 33.2 & 5.30 & 196.0 & 53.5 & 54.8 & 25.1 & empty \\
\hline 08 & 36.8 & 5.50 & 192.0 & 59.9 & 60.3 & 31.5 & empty \\
\hline
\end{tabular}

*Eagle ate first capture fish; was captured on second fish soon after. 
APPENDIX D

MAPS OF BALD EAGLE COMMUNAL ROOSTS ON LAKE PEND OREILLE, 1985-86 AND 1986-87

D-I 


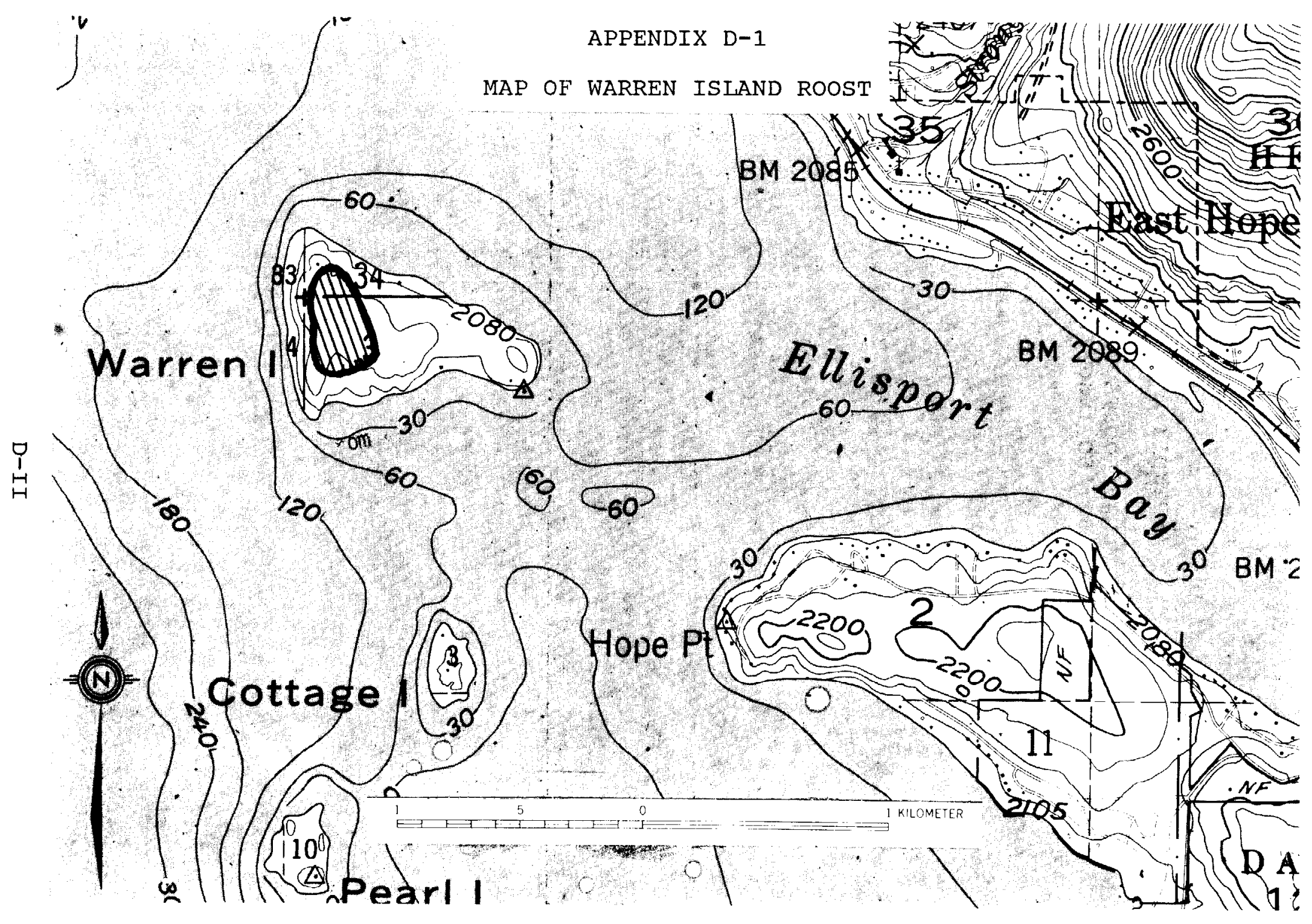




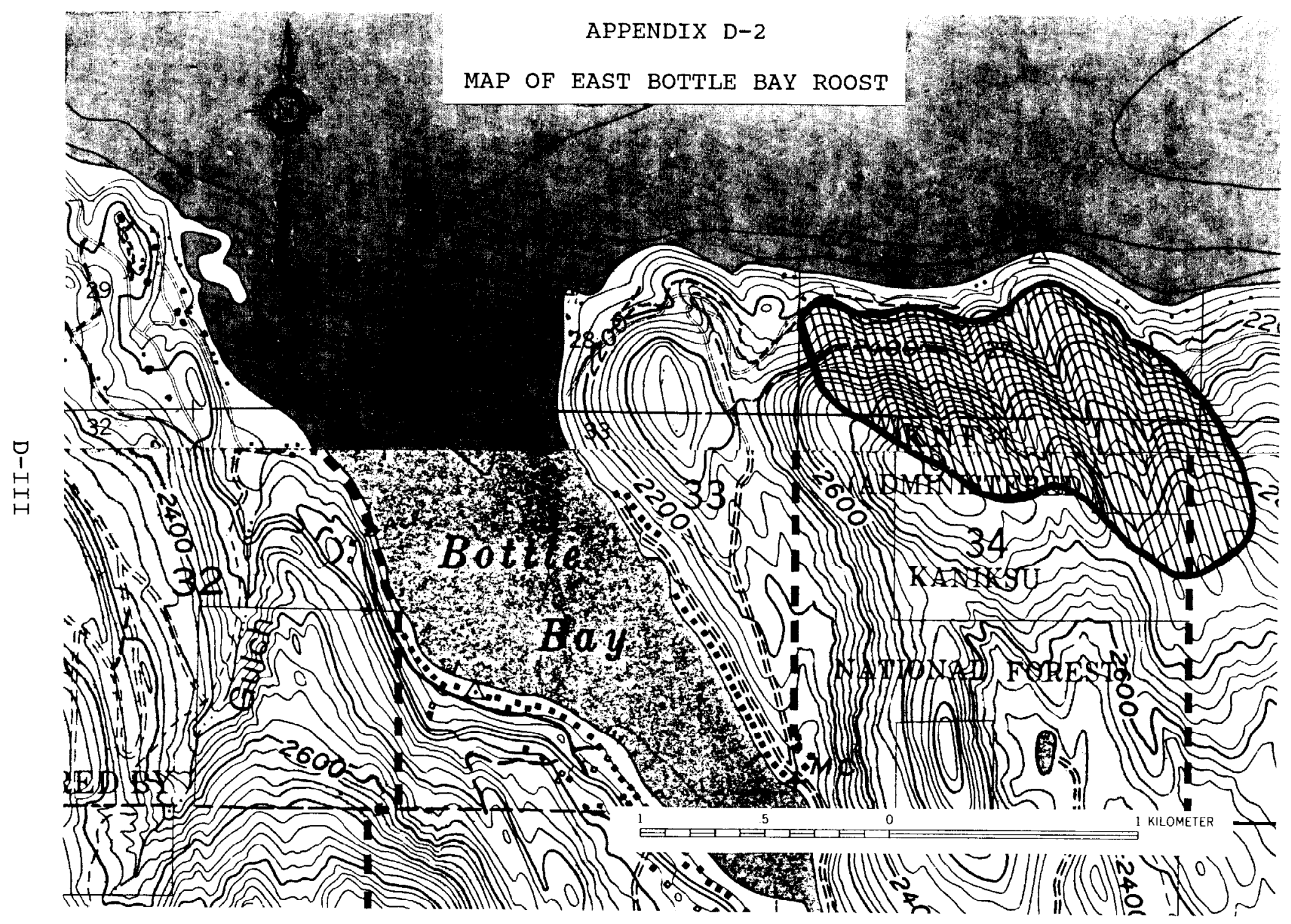




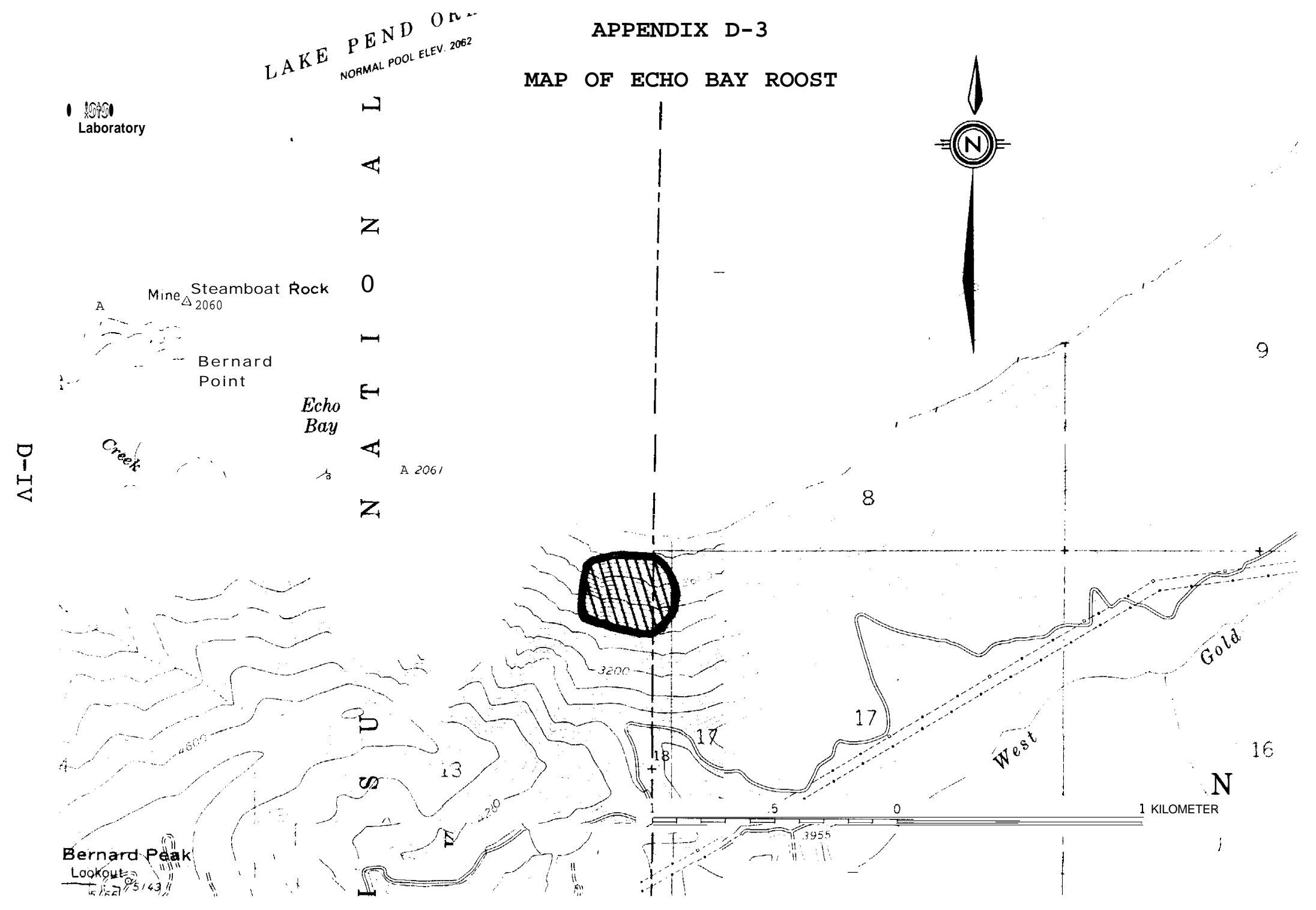

